\begin{abstract}
UNIVERSIDADE DE SÃO PAULO
FACULDADE DE MEDICINA DE RIBEIRÃO PRETO

PROGRAMA DE PÓS-GRADUAÇÃO MESTRADO PROFISSIONAL EM

HEMOTERAPIA E BIOTECNOLOGIA
\end{abstract}

CLAUDIANE APARECIDA DA SILVA

IMPLANTAÇÃO DE GESTÃO DA QUALIDADE EM UMA AGÊNCIA TRANSFUSIONAL UTILIZANDO BENCHMARKING

Ribeirão Preto - SP

2018 


\title{
IMPLANTAÇÃO DE GESTÃO DA QUALIDADE EM UMA AGÊNCIA TRANSFUSIONAL UTILIZANDO BENCHMARKING
}

\author{
Versão Corrigida
}

Dissertação apresentada à Faculdade de Medicina de Ribeirão Preto da Universidade de São Paulo para a obtenção do título de Mestre em Ciências.

Área de concentração: Hemoterapia e Medicina Transfusional

Orientador: Prof. Dr. José Carlos Borges

Ribeirão Preto - SP

2018 
Autorizo a reprodução e divulgação total ou parcial deste trabalho, por qualquer meio convencional ou eletrônico, para fins de estudo e pesquisa, desde que citada a fonte.

Catalogação na publicação

Serviço de Biblioteca e Documentação

Hemocentro de Ribeirão Preto - Universidade de São Paulo

S586i

Silva, Claudiane Aparecida da

Implantação de gestão da qualidade em uma agência transfusional utilizando benchmarking./ Claudiane Aparecida da Silva - Ribeirão Preto, 2018.

$89 f . ;$ il. $30 \mathrm{~cm}$

Dissertação de mestrado apresentada à Faculdade de Medicina de Ribeirão Preto, Universidade de São Paulo.

Área de concentração: Hemoterapia e Medicina

Transfusional

Orientador: José Carlos Borges

1. Gestão da qualidade. 2. Serviço de hemoterapia.

3. Benchmarking. 4. Manual de boas práticas.

CDU 615.38.006 


\section{FOLHA DE APROVAÇÃO}

Nome: SILVA, Claudiane Aparecida da

Título: "IMPLANTAÇÃO DE GESTÃO DA QUALIDADE EM UMA AGÊNCIA TRANSFUSIONAL UTILIZANDO BENCHMARKING"

Dissertação apresentada à Faculdade de Medicina de Ribeirão Preto da Universidade de São Paulo para a obtenção do título de Mestre em Ciências.

Aprovado em: 15/03/2018

Banca examinadora

Prof. Dra. : Sônia Valle Walter Borges de Oliveira Instituição: Faculdade de Economia e Administração de Ribeirão Preto - USP Julgamento: Aprovada

Prof. Dra. : Silvia Renata Cornelio Parolin Rizzo

Instituição: Externa - COLSAN - SP

Julgamento: Aprovada

Prof. Dr. : Edson Zangiacomi Martinez

Instituição: Faculdade de Medicina de Ribeirão Preto - USP

Julgamento: Aprovada 
Dedico este trabalho a todos os profissionais que trabalham em agências transfusionais, que buscam pela qualidade dos serviços prestados aos pacientes. 


\section{AGRADECIMENTOS}

A Deus por ter me dado saúde e força para superar as dificuldades e realizar o sonho de fazer mestrado.

Ao meu esposo, amigo e companheiro de todas as horas, Cledson Ferreira da Silva, pelo amor e esforço para que eu chegasse a esta etapa da minha vida.

Ao meu filho e meus pais, pela compreensão da minha ausência em diversos momentos e encorajamento constante.

À Dra. Hildenete Monteiro Fortes, responsável técnica da AT-HUJM, pelo incentivo.

Às minhas amigas Suelena e Amanda pelo apoio desde o início desta caminhada.

A toda a equipe do Hemocentro de Ribeirão Preto, pela dedicação na organização de todo o Programa de Mestrado, em especial a Raquel Aparecida Botelho, que desde o início sempre me motivou com a seguinte frase: "já deu tudo certo".

Aos colegas da minha turma do Mestrado Profissional em Hemoterapia que estiveram juntos em todos os momentos desta jornada.

Ao meu orientador, Prof. Dr. José Carlos Borges, pela acolhida, contribuições e profissionalismo para a realização deste trabalho.

À Dra. Eugênia M. Amorim Ubiali, por suas prontas e sinceras contribuições no aprimoramento desta dissertação.

Aos meus colegas de trabalho, que depositaram confiança na realização deste sonho, e contribuíram para seu produto, que esperamos dar continuidade.

Enfim, agradeço a todos que participaram, em diversos e inúmeros momentos da minha vida, tornando eu a pessoa que sou e que se traduz, em parte, nesta contribuição científico-acadêmica e profissional. 


\section{RESUMO}

Silva, Claudiane Aparecida. IMPLANTAÇÃO DE GESTÃO DA QUALIDADE EM UMA AGÊNCIA TRANSFUSIONAL UTILIZANDO BENCHMARKING. 2018. 89f. Dissertação (Mestrado em Hemoterapia e Medicina Transfusional) - Faculdade de Medicina de Ribeirão Preto, Universidade de São Paulo, Ribeirão Preto, 2018.

Em serviços na área da saúde, é fundamental atingir segurança e obter produtos e serviços com qualidade, o que requer padronização de processos e estabelecimento de normas e condutas. Serviços de hemoterapia necessitam garantir que seus procedimentos ocorram sob condições controladas, para assegurar a qualidade dos produtos e serviços prestados aos doadores e pacientes. Diante da reconhecida importância da Gestão da Qualidade (GQ) na prática hemoterápica, este trabalho visou promover e descrever as mudanças advindas da implantação da Gestão da Qualidade, na Agência Transfusional do Hospital Universitário Júlio Müller (ATHUJM), de Cuiabá-MT. Trata-se de uma pesquisa aplicada, do tipo pesquisa-ação de natureza quali-quantitativa, com abordagem intervencionista. Foram analisados os documentos elaborados, as ações implementadas e os benefícios alcançados. $O$ trabalho foi realizado através de um benchmarking entre o Hemocentro de Ribeirão Preto (Hemocentro-RP) e o HUJM, visando à implantação da GQ na AT-HUJM. Benchmarking pode ser definido como um processo contínuo e sistemático de avaliação de produtos, serviços e metodologias de organização do trabalho que, pela comparação de desempenhos, visa identificar oportunidades de melhoria. Ações internas são comparadas e modificadas em face de padrões externos, sendo esta uma forma eficaz de se definir metas e motivar as equipes de trabalho. Os resultados demonstraram que a implantação da GQ na AT-HUJM, gerou resultados positivos, como a revisão e a criação de documentos da qualidade e a implantação de ações que contribuíram para a padronização dos processos. Isto melhorou a imagem da AT perante a direção do HUJM, tornando-a um exemplo para os demais setores. Também como produto deste estudo, foi elaborado um manual de boas práticas que sugere requisitos para o funcionamento operacional de uma AT. Por considerar as características do serviço e a legislação vigente, o manual poderá ser uma ferramenta importante tanto na organização como na gestão das agências transfusionais no Brasil.

Palavras-chave: Gestão da Qualidade. Serviço de Hemoterapia. Benchmarking. Manual de boas práticas. 


\begin{abstract}
Silva, Claudiane Aparecida. IMPLANTATION OF QUALITY MANAGEMENT IN A TRANSFUSION AGENCY USING BENCHMARKING. 2018. 89 f. Dissertação (Mestrado em Hemoterapia e Medicina Transfusional) - Faculdade de Medicina de Ribeirão Preto, Universidade de São Paulo, Ribeirão Preto, 2018.

In health services, it is fundamental to achieve safety and obtain products and services with quality, which requires standardization of processes and establishment of standards and conduct. Hemotherapy services need to ensure that procedures take place under controlled conditions to ensure the quality of products and services provided to donors and patients. In view of the acknowledged importance of Quality Management (QM) in hemotherapy practice, this work aimed to promote and describe the changes arising from the implementation of Quality Management in the Transfusion Agency of the University Hospital Júlio Müller (TA-HUJM) from CuiabáMT. It is an applied research, of type research-action of quali-quantitative nature, with interventionist approach. We analyzed the documents elaborated, the actions implemented and the benefits achieved. The work was carried out through a benchmarking between the Hemocenter of Ribeirão Preto and the HUJM, aiming at the implementation of QM at TA-HUJM. Benchmarking can be defined as a continuous and systematic process of evaluation of products, services and methodologies of work organization that, by comparing performance, aims to identify opportunities for improvement. internal actions are compared and modified in the face of external standards, which is an effective way to set goals and motivate work teams. The results demonstrated that the implantation of the GQ in the AT-HUJM, generated positive results, such as the revision and creation of quality documents and the implementation of actions that contributed to the standardization of processes. This improved the image of the TA before the direction of the HUJM, making it an example for the other sectors. Also as a product of this study, a manual was developed that suggests requirements for the operational functioning of a TA. Considering the characteristics of the service and the current legislation, the manual can be an important tool both in the organization and in the management of transfusion agencies in Brazil.
\end{abstract}

Keywords: Quality Management. Hemotherapy Service. Benchmarking. Good practice manual. 


\section{LISTA DE FIGURAS}

Figura 1 - Organograma da AT-HUJM .25

Figura 2 - Modelo de cabeçalho padrão dos Registros da Qualidade da AT-HUJM 27 Figura 3 - Modelo de rodapé padrão dos Formulários de Registros da AT-HUJM ...28

Figura 4 - Macroprocesso da AT-HUJM 31

Figura 5 - Modelo de capa padrão dos Procedimentos Operacionais da AT- HUJM32

Figura 6 - Modelo de capa padrão dos Protocolos Clínicos da AT- HUJM .34

Figura 7 - Modelo de capa padrão dos Manuais da AT-HUJM..................................35

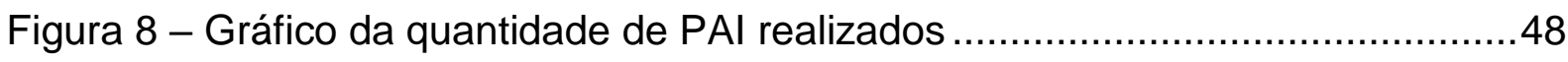

Figura 9 - Gráfico do índice de frequência de PAI positivo .......................................49

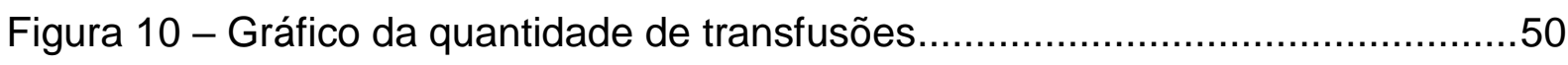

Figura 11 - Gráfico do índice de transfusões por clínica ......................................50

Figura 12 - Gráfico da quantidade de transfusões $x$ reações transfusionais .............51

Figura 13 - Gráfico do índice de reações transfusionais/1000 transfusões ...............52

Figura 14 - Gráfico da quantidade de reações transfusionais por tipo de hemocomponente.

Figura 15 - Gráfico do índice reações transfusionais por tipo de hemocomponente 53

Figura 16 - Gráfico da quantidade de reações transfusionais por tipo .53

Figura 17 - Gráfico do índice perfil epidemiológico das reações transfusionais .......54

Figura 18 - Gráfico da quantidade de bolsas compatibilizadas .............................54

Figura 19 - Gráfico do índice de compatibilização desnecessária............................55

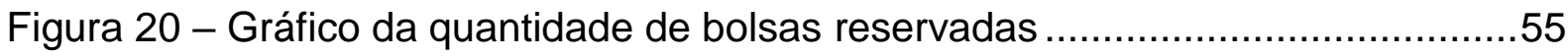

Figura 21 - Gráfico do Índice de reservas cirúrgicas não utilizadas .......................56

Figura 22 - Gráfico da quantidade de hemocomponentes recebidos .......................57

Figura 23 - Gráfico da quantidade de hemocomponentes descartados por

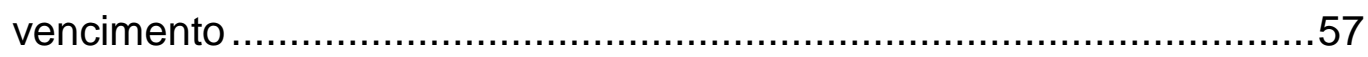

Figura 24 - Gráfico do índice de bolsas descartadas por vencimento .....................58

Figura 25 - Gráfico da quantidade de hemocomponentes descartados por outros motivos .59

Figura 26 - Gráfico do índice de bolsas descartadas por outros motivos 60 
Figura 27 - Imagens da entrega do selo "Implantando Qualidade" para a AT- HUJM 63

Figura 28 - Imagem da rede intranet do HUJM, em junho de 2017 ......................64 Figura 29 - Comparação dos resultados das inspeções da vigilância sanitária na ATHUJM .65 


\section{LISTA DE QUADROS}

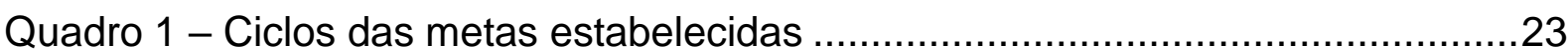

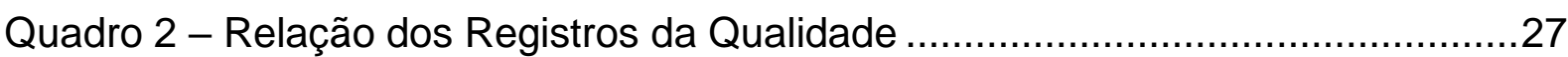

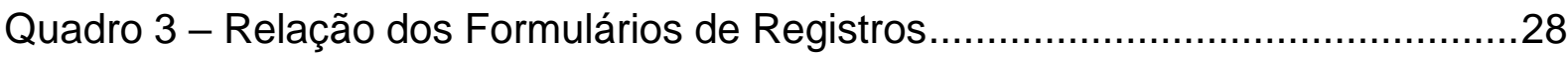

Quadro 4 - Relação dos Procedimentos Operacionais Padrão ...............................33

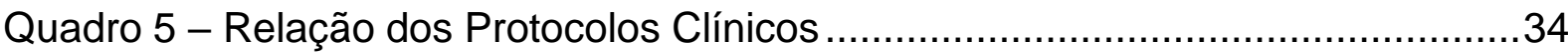

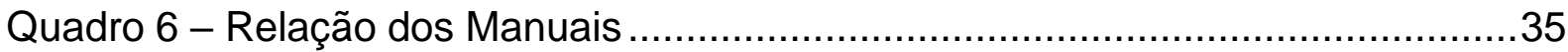

Quadro 7 - Não conformidades referentes à coleta de amostras e cadastro de

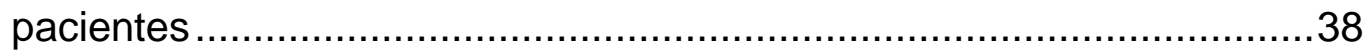

Quadro 8 - Não conformidades referentes à imuno-hematologia do receptor ...........38

Quadro 9 - Não conformidades referentes à transfusão.........................................39

Quadro 10 - Não conformidades referentes à garantia da qualidade .......................40

Quadro 11 - Não conformidades referentes à estrutura física e instalações .............40

Quadro 12 - Não conformidades referentes às informações gerais .........................41

Quadro 13 - Indicadores Implantados na AT- HUJM .........................................46

Quadro 14 - Fórmulas de cálculos dos indicadores da AT-HUJM ..........................46 


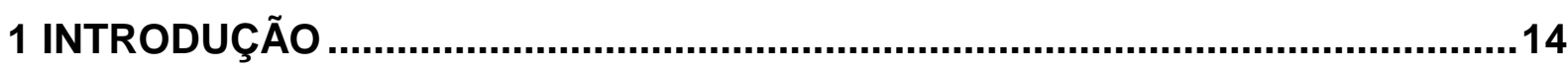

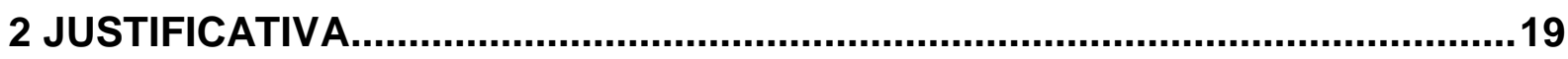

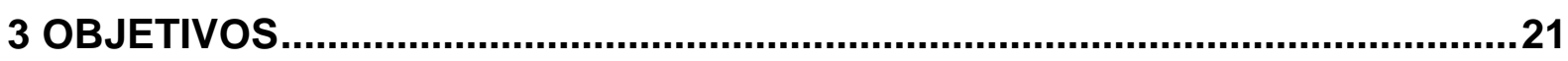

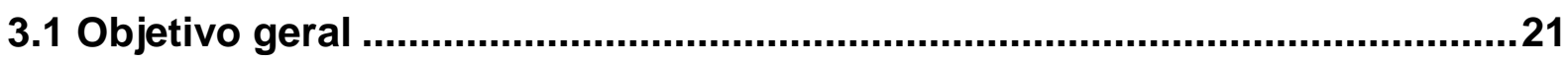

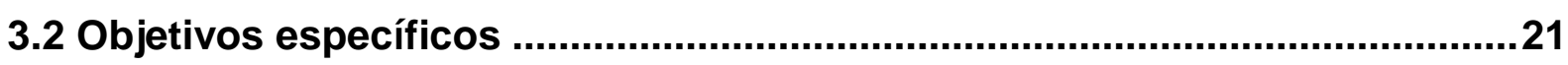

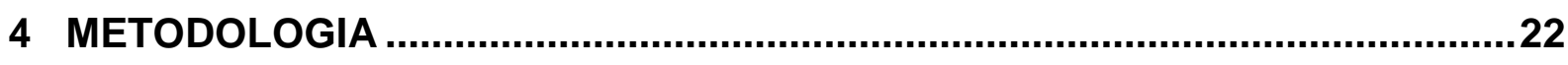

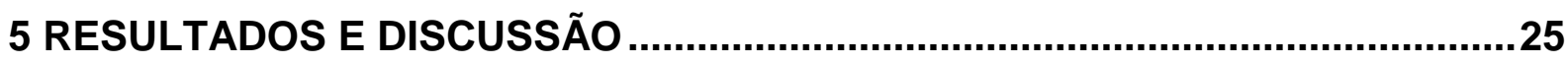

5.1 Documentos elaborados pela Gestão da Qualidade .....................................25

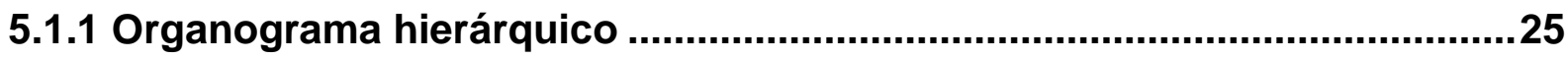

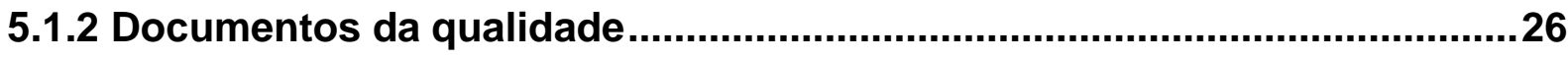

5.2 Ações implantadas pela Gestão da Qualidade ..............................................29

5.2.1 Revisão da política da qualidade (missão, visão e valores)........................29

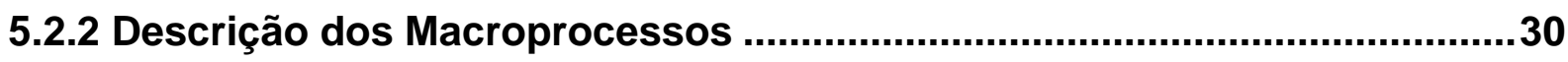

5.2.3 Gerenciamento e padronização dos documentos..........................................

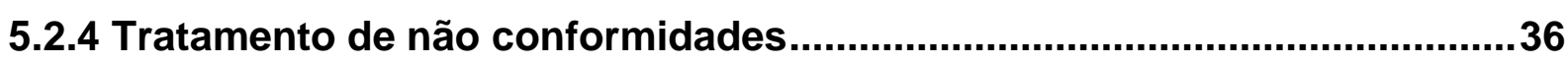

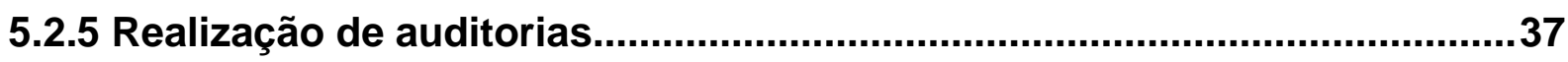

5.2.6 Desenvolvimento de educação continuada ................................................. 41

5.2.7 Tratamento de reclamações e sugestões dos usuários - Ouvidoria ........42

5.2.8 Realização de pesquisas de satisfação e de opinião..................................... 43

5.2.9 Elaboração do Plano de Contingência para a cadeia do frio ......................43

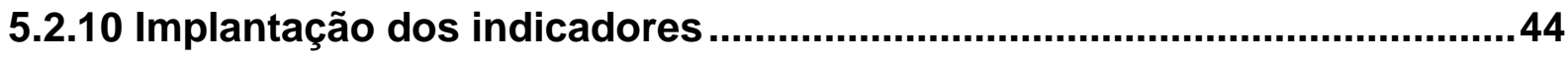

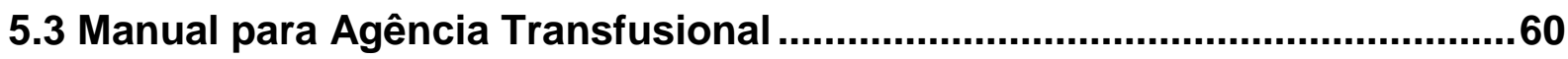

5.4 Benefícios obtidos com a implantação da GQ ..............................................62

6 CONCLUSÃO

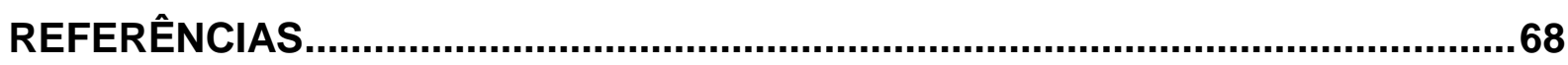

APÊNDICE - MANUAL PARA AGÊNCIA TRANSFUSIONAL .............................71 


\section{INTRODUÇÃO}

O conceito de qualidade teve seu marco histórico em 1920, com o início da era industrial e a produção em massa e, nesta época, estava relacionado à inspeção do produto final. A evolução, desde o primeiro conceito, possibilita, atualmente, a análise de todos os processos envolvidos com a produção e a satisfação do usuário e, neste contexto, é possível definir a qualidade esperada de determinado serviço ou produto final, considerando a avaliação de seus processos de produção (MALIK; SCHIESARI, 1998).

Assim, a avaliação da qualidade deve seguir critérios previamente estabelecidos que precisam estar em conformidade com o produto ou serviço oferecido, além de utilizar as ferramentas disponíveis, dentro do escopo do Sistema de Gestão da Qualidade - SGQ, para o monitoramento de todo o processo. A interação entre os processos, produtos e serviços, ferramentas de avaliação, monitoramento e documentação, configuram o SGQ, por meio do qual é possível o gerenciamento e a prevenção de não conformidades, alcançando-se, continuamente, melhores resultados (MALIK; SCHIESARI, 1998).

O SGQ, quando aplicado aos serviços de hemoterapia, possibilita a padronização dos procedimentos, a adequação e o controle dos processos, desde a seleção de doadores até a transfusão sanguínea, permitindo o atendimento às legislações vigentes e a constante melhoria da qualidade dos hemocomponentes oferecidos e dos serviços prestados.

Em 1980, foi criado o Programa Nacional de Sangue e Hemoderivados para organização e edição de normas de regulamentação da atividade hemoterápica no Brasil. Em seguida, o programa contou com a criação de uma comissão responsável por implantar nos serviços de hemoterapia, as diretrizes para não comercialização de sangue, atendimento universal da população e qualidade na prestação dos serviços. Além disso, uma cooperação técnica entre a França e o Brasil foi importante para uma proposta de padrões internacionais de segurança transfusional e de qualidade, inclusive em relação à utilização dos controles de qualidade na rotina laboratorial (JUNQUEIRA et al., 2005). 
Entretanto, as ações e percepções de qualidade, nos serviços de hemoterapia, somente tiveram um efetivo alcance social em 1998, quando o governo Federal lançou, como tema da Meta Mobilizadora Nacional do Setor de Saúde, o lema "sangue com garantia de qualidade em todo o seu processo até 2003", que fortaleceu a prática hemoterápica brasileira com qualidade e segurança transfusional (BRASIL, 1999).

A gestão da qualidade (GQ), na área da hemoterapia, é ainda mais complexa, pois a qualidade inicia-se na captação dos doadores de sangue e estende-se até a assistência do receptor, durante e/ou após o ato transfusional, o que garante a rastreabilidade dos produtos derivados do sangue, do início ao final do processo (TAKAKURA, 2011).

A partir da consciência dos riscos do tratamento transfusional e de suas consequências, potencialmente, desastrosas, a gestão da qualidade tem conquistado, cada vez mais, um lugar na medicina transfusional (MOORE; FOSS, 2003). Ela tem se tornado um dos pilares da melhoria da segurança transfusional, por meio da utilização de suas diversas ferramentas, como: procedimentos operacionais padrão, indicadores de qualidade, tratamento das sugestões e reclamações dos usuários, processos de proposições de ações preventivas e corretivas, assim como ferramentas de identificação, análise, avaliação dos erros e gestão de riscos (CAMPOS; SANTOS, 2010).

É notório o avanço realizado, nas últimas décadas, no que se refere às questões da segurança transfusional, da produção de serviços de hemoterapia e do controle desses processos através dos programas de qualidade (SOUZA, 2013).

Segundo a American Association of Blood Banks (AABB, 2014) os SGQ de Bancos de Sangue ou Serviços de Transfusão, em medicina transfusional, devem adotar os seguintes princípios:

1. Organização e liderança: uma estrutura organizacional que defina e documente, claramente, os responsáveis pelo fornecimento de sangue e seus componentes, de serviços, bem como a hierarquia das pessoas responsáveis pelas funções fundamentais da qualidade;

2. Foco no cliente: a direção executiva identificar os clientes e suas necessidades e expectativas para produtos e serviços;

3. Instalações, ambiente de trabalho e segurança: políticas, processos e procedimentos que garantam a provisão de condições ambientais seguras, 
organização adequada para as atividades realizadas, programas de segurança para atender a regulamentações municipais, estaduais e federais, quando aplicáveis;

4. Recursos humanos: processo para garantir o emprego de um número adequado de pessoas, qualificadas por formação, treinamento e/ou experiência, mantendo as descrições de cada cargo, com especificações das qualificações adequadas;

5. Gestão de fornecedores e materiais: políticas, processos e procedimentos para avaliação da capacidade dos fornecedores de materiais críticos, equipamentos e serviços, para atender, de forma consistente, aos requisitos especificados;

6. Gestão de equipamentos: identificação dos equipamentos críticos para o fornecimento de sangue e seus componentes, derivados, tecidos e/ou serviços, através de políticas, processos e procedimentos que assegurem calibração, manutenção, monitoramento e controle de equipamentos em conformidade com os padrões e outros requisitos especificados;

7. Gestão de processos: processos e procedimentos validados, que garantam a qualidade do sangue, componentes, tecidos, derivados e serviços, garantindo que essas políticas, processos e procedimentos sejam realizados sob condições controladas;

8. Documentos e registros: políticas, processos e procedimentos para assegurar que os documentos sejam identificados, revisados, aprovados e mantidos e que registros sejam criados, armazenados e arquivados de acordo com as políticas de retenção de registros;

9. Gestão da informação: processos para apoiar implementação e modificação de software, hardware e banco de dados, relacionados aos requisitos dos padrões, manter um sistema alternativo que garanta funcionamento contínuo na eventualidade de dados informatizados e funções ficarem indisponíveis;

10. Gestão de eventos não conformes: políticas, processos e procedimentos para assegurar relato, avaliação, investigação e monitoramento de desvios no atendimento ou falha em atender aos requisitos especificados. Comunicação de desvios, não conformidades e eventos adversos, de acordo com os requisitos especificados, e às autoridades sanitárias conforme a regulamentação vigente;

11. Monitoramento e auditorias: políticas, processos e procedimentos para assegurar que as avaliações internas e externas das operações e do sistema de 
qualidade sejam agendadas e realizadas. Um programa que monitore e direcione as práticas de transfusão para todos os tipos de produto.

12. Melhoria de processos: políticas, processos e procedimentos para coleta de dados, análise e acompanhamentos de questões que exigem ação corretiva e preventiva, incluindo eventos de quase erro.

Para se alcançar qualidade nos sistemas de saúde, é imprescindível que ocorra intervenção, também, nos processos administrativos da organização e na sua gestão. As organizações com processos mais estruturados fornecem aos seus clientes garantia de melhores serviços e, consequentemente, melhores condições de restabelecimento da saúde (BONATO, 2011).

Para avaliação dos resultados, as organizações têm buscado ferramentas que forneçam informações relevantes. Os indicadores aparecem como um modo de gerar informações e monitorar a qualidade dos serviços oferecidos e, com a incorporação desta prática, a importância dos indicadores vem sendo destacada para garantir a qualidade dos processos das instituições de saúde (MOURA et al., 2009).

De acordo com o anexo IV da Portaria de Consolidação MS n 05, de 03 de outubro de 2017, que institui o regulamento técnico de procedimentos hemoterápicos, "o serviço de hemoterapia disporá de políticas e ações que assegurem a qualidade de produtos e serviços, garantindo que os procedimentos e processos ocorram sob condições controladas" (BRASIL, 2017).

Assim como em todos os serviços na área da saúde, na hemoterapia, também, é imprescindível atingir segurança e obter produtos e serviços com qualidade, o que se concretiza através da padronização de processos e o estabelecimento de normas e condutas. E esta filosofia da qualidade, não difere da aplicada nas indústrias. A adequação do produto ou serviço aos anseios do cliente é um fundamento de qualidade perfeitamente aplicável aos diversos serviços de assistência à saúde (MENDES, 1998).

Atualmente, as exigências da qualidade são tidas como atributos essenciais a sobrevivência das organizações no mercado, com isso, as instituições passaram a descobrir mais rapidamente o que seus concorrentes estavam fazendo de melhor. Essas descobertas ocorreram por meio da pratica de benchmarking ou técnica de referenciação, iniciada pela empresa Xerox, no final da década de 1970, quando da suspeita de que o custo da produção havia sido maior que sua principal concorrente 
japonesa. Benchmarking é um processo contínuo de medidas de produtos, serviços e práticas para comparação com os competidores de mercado ou instituições reconhecidas como líderes no ramo (GALORO et al., 2009).

Também podemos definir benchmarking como a busca de melhores práticas em uma instituição, que conduzam a um desempenho superior. É visto como um processo positivo e proativo por meio do qual uma instituição examina como outra realiza uma função específica, a fim de melhorar a realização da mesma ou de uma função semelhante (BOGAN; ENGLISH, 1997), sendo, portanto, uma ferramenta de gestão da qualidade que permite a comparação dos desempenhos de processos entre organizações.

Apesar do seu neologismo, benchmarking é mais do que uma simples combinação de palavras - exprime uma filosofia. Este processo não se limita à simples identificação das melhores práticas nem é um método aleatório de recolher informação. Trata-se de um processo sistemático estruturado, etapa a etapa, com o intuito de avaliar os métodos de trabalho no mercado (CAMP, 1998).

Benchmarking foi definido por Bittar (2001), como o ato de comparar sistematicamente informações ou, ainda, um padrão de referência pelo qual outros podem ser medidos ou julgados. Pode ser classificado como: interno, quando a comparação ocorre por processos semelhantes entre setores de uma mesma instituição; funcional, se a comparação ocorre entre instituições semelhantes, mas que atuam em mercados distintos; e competitivo, forma mais utilizada, que ocorre a partir da comparação de processos semelhantes entre concorrentes diretos.

Conforme, Campos e Santos (2010), o objetivo de benchmarking é comparar desempenhos e identificar oportunidades de melhoria - é como um atalho para a excelência. Ações internas são comparadas e modificadas face a padrões externos, para tentar melhorar e avançar ao longo do conhecimento e da identificação das melhores práticas e projeção do desempenho futuro. Em que podemos ver onde estamos e para onde queremos ir através de uma comparação e partilha de informação, para alcançar uma melhoria do desempenho e de progresso contínuo.

A partir destas definições, esta pesquisa levanta o seguinte problema: como promover a implantação de gestão da qualidade em uma agência transfusional utilizando benchmarking? Com base neste questionamento, este trabalho busca descrever as mudanças ocorridas com a implantação da $G Q$ na agência 
transfusional do Hospital Universitário Júlio Müller (HUJM), de Cuiabá - MT, por meio de benchmarking com o Hemocentro de Ribeirão Preto.

\section{JUSTIFICATIVA}

No ano de 2015 ocorreram visitas da Vigilância Sanitária local ao HUJM, e um dos setores apontados como mais críticos, correndo risco de ser interditado, foi a agência transfusional. No final do referido ano, foi desenvolvido o plano diretor estratégico (PDE) do HUJM para o biênio 2016-2017, visando modernizar a gestão e adequar o cuidado administrado à política nacional de atenção hospitalar vigente, com ênfase em humanização, na qualidade do cuidado e na segurança do paciente.

A segurança do paciente tem sido considerada um atributo prioritário da qualidade dos sistemas de saúde de todo o mundo, mas o assunto qualidade em saúde e segurança do paciente em instituições públicas brasileiras é bastante recente. Neste sentido, considerando a realidade do HUJM, verificou-se uma necessidade premente de implantação e implementação dessas ações, as quais foram amplamente incentivadas.

A agência transfusional foi um dos primeiros setores do HUJM em que a equipe técnica e a direção administrativa do hospital iniciaram esforços para análise e tratamento das não conformidades apontadas, despertando, assim, grande interesse pela qualidade do serviço.

A Resolução RDC ํo 151, de 21 de agosto de 2001, que aprovou o Regulamento Técnico sobre Níveis de Complexidade dos Serviços de Hemoterapia, define a nomenclatura e o conceito de AT como:

Localização, preferencialmente intra-hospitalar, com a função de armazenar, realizar testes de compatibilidade entre doador e receptor e transfundir os hemocomponentes liberados. O suprimento de sangue a estas agências realizar-se-á pelos Serviços de Hemoterapia de maior complexidade (BRASIL, 2001, p.2).

Antunes et al. (2008) afirmam que é preciso garantir a terapêutica transfusional adequada ao paciente; assim, a realização do teste certo, com a amostra certa, para obter o resultado certo, assegura a transfusão do hemocomponente certo, para o doente certo, e previne a ocorrência de erros que 
são uma das principais causas de morbidade e mortalidade decorrentes da terapia sanguínea. Essas ações somente são obtidas em serviços que promovem ações preventivas na forma de tratamentos de ações não conformes e, também, de promoções permanentes de melhorias que garantam a qualidade de seus serviços.

Este estudo se justifica porque a implantação da GQ na AT-HUJM, por meio de benchmarking com o Hemocentro-RP seria de grande importância para aumentar a segurança transfusional aos pacientes assistidos pelo hospital.

Atualmente, a prática de benchmarking possibilita a avaliação do desempenho de todos os processos de determinado serviço, comparando seus dados com serviços de referência (RICÓS et al., 2004).

O hemocentro de Ribeirão Preto foi escolhido para benchmarking por apresentar sistema de gestão da qualidade robusto e internalizado em toda sua rede, com certificação ISO desde 1999 e com acreditação da AABB desde 2003 em todos os seus processos. 


\section{OBJETIVOS}

\subsection{Objetivo geral}

Implantar a GQ na AT - HUJM, através de um benchmarking com o Hemocentro-RP.

\subsection{Objetivos específicos}

1. Identificar as rotinas aplicadas na AT;

2. Conscientizar a equipe da AT da importância da gestão da qualidade nos processos;

3. Viabilizar a GQ aplicável aos processos da AT;

4. Estabelecer indicadores de desempenho para os processos da AT;

5. Desenvolver um Manual aplicável a qualquer AT. 


\section{METODOLOGIA}

Esta pesquisa foi conduzida de acordo com a Resolução № 466 de 12 de dezembro de 2012, do Conselho Nacional de Saúde. O projeto de pesquisa foi submetido ao Comitê de Ética em Pesquisa do HUJM, da Universidade Federal de Mato Grosso (UFMT), através do sistema Plataforma Brasil, sendo aprovado de acordo com o Parecer $n^{-}$1.996.572. Trata-se de uma pesquisa aplicada, do tipo pesquisa-ação de natureza quali-quantitativa, com abordagem intervencionista.

O HUJM da UFMT é uma instituição, inaugurada em 1984, para servir de campo de estágio para os alunos dos cursos de saúde e prestar assistência hospitalar de média e alta complexidade para a população do estado de Mato Grosso e região. No final de 2014, o HUJM passou a fazer parte da Empresa Brasileira de Serviços Hospitalares (EBSERH), empresa pública vinculada ao Ministério da Educação, responsável pela gestão de hospitais universitários federais. Entre as atribuições assumidas pela empresa, está à coordenação e avaliação da execução das atividades dos hospitais, apoio técnico à elaboração de instrumentos de melhoria da gestão e elaboração da matriz de distribuição de recursos.

A Fundação Hemocentro de Ribeirão Preto (FUNDHERP) foi criada em 1990 para administrar toda a rede de atendimento do Centro Regional de Hemoterapia que é um departamento do Hospital das Clínicas da Faculdade de Medicina de Ribeirão Preto, Universidade de São Paulo. Está localizado na região nordeste do estado de São Paulo, com uma rede composta por diversos serviços de hemoterapia de diferentes complexidades, que atende uma região com uma população de cerca de cinco milhões de habitantes.

Um fato inicial na implantação da gestão da qualidade na AT-HUJM ocorreu em 2016, com a nomeação do cargo de supervisor técnico, visando acompanhar a equipe técnica e dar início a práticas de gestão dos processos.

Foi elaborado um projeto de pesquisa para a implantação da gestão da qualidade na AT-HUJM utilizando a técnica de benchmarking, através da assinatura de um Termo de Acordo entre a Fundação Hemocentro de Ribeirão Preto (FUNDHERP), representada por seu diretor presidente, e a AT-HUJM, por seu superintendente. $\mathrm{O}$ acordo foi estabelecido pelo prazo de 02 (dois) anos, visando $\mathrm{O}$ 
desenvolvimento da política de benchmarking, troca de indicadores, adequação de metas e aprimoramento do sistema da qualidade de ambas as instituições.

Foi realizada uma análise minuciosa dos diferentes processos envolvidos na AT-HUJM, incluindo aspectos técnicos, organizacionais e administrativos, além de identificação de não conformidades e aplicação de ações corretivas. Foi utilizada uma metodologia sistemática, no sentido de transformar as realidades observadas, a partir do conhecimento e da ação dos elementos envolvidos na pesquisa. A técnica de observação foi utilizada para examinar os fatos e aproximar do objeto de estudo. As técnicas para análise de dados foram do tipo quantitativo e qualitativo.

Foram estabelecidas metas para a AT, visando ajustes nas rotinas existentes e incorporação de novas rotinas quando necessário (Quadro 1).

\section{Quadro 1 - Ciclos das metas estabelecidas}

\begin{tabular}{|c|c|}
\hline Ciclos & Metas \\
\hline $1^{\circ}$ Ciclo & $\begin{array}{l}\text { Revisão do organograma } \\
\text { Revisão da política da qualidade } \\
\text { Mapeamento dos macroprocessos } \\
\text { Revisão e desenvolvimento de procedimentos operacionais } \\
\text { Criação de protocolos clínicos }\end{array}$ \\
\hline $2^{\circ}$ Ciclo & $\begin{array}{l}\text { Auditorias } \\
\text { Registro e tratamento das não conformidades } \\
\text { Implantação de registros e formulários }\end{array}$ \\
\hline $3^{\circ}$ Ciclo & $\begin{array}{l}\text { Benchmarking com o Hemocentro de Ribeirão Preto } \\
\text { Implantação de indicadores }\end{array}$ \\
\hline $4^{\circ}$ Ciclo & $\begin{array}{l}\text { Análise dos indicadores } \\
\text { Elaboração de um manual para agências transfusionais. }\end{array}$ \\
\hline
\end{tabular}

Fonte: da autora (2017).

Todos os profissionais técnicos e administrativos foram mobilizados a adotar boas práticas de gestão na $A T$, focando na implantação da qualidade e na segurança do paciente. Foram implantadas atividades ligadas à motivação e conscientização dos profissionais, valorização do trabalho e inclusão em suas rotinas, a importância de sua missão e do compromisso institucional.

Estratégias de comunicação e a atuação de liderança da supervisão técnica foram utilizadas para o envolvimento de todos nas atividades propostas.

Reuniões periódicas da equipe da AT-HUJM foram realizadas para planejar e avaliar os planos de ação sobre os processos de trabalho.

No segundo semestre de 2016, foi necessário um planejamento prévio, bem como um cronograma para realização da visita técnica no Hemocentro-RP, durante 
uma semana, com os objetivos de conhecer o modelo de sistema de gestão da qualidade empregado na referida instituição, através de análise documental, e comprovar os diferenciais em termos de desempenho, principalmente, para identificar as causas desses diferenciais. Foram coletadas informações, indicadores e demais dados relativos à gestão da qualidade e setores de apoio, através de perguntas específicas pré-estabelecidas e consultas aos seguintes documentos:

- Política da Qualidade Institucional;

- Mapeamento dos Processos;

- Descrição e Registros dos Procedimentos Operacionais Padrão de cada área;

- Fluxogramas;

- Registros de Tratamento das Não Conformidades;

- Definição dos Indicadores;

- Registros de Auditorias.

Além do setor de gestão da qualidade, foram realizadas visitas nos seguintes setores, com duração de um dia em cada setor:

- Gestão de materiais e serviços;

- Gestão de equipamentos;

- Almoxarifado;

- Agência Transfusional do Hospital das Clínicas da Faculdade de Medicina de Ribeirão Preto da Universidade de São Paulo.

No primeiro semestre de 2017, foram definidos os Indicadores da Qualidade para a AT-HUJM, baseados no modelo das informações utilizadas para monitorar os processos realizados no Hemocentro-RP. Para aplicação dos indicadores, foi realizada uma análise retrospectiva dos dados do ano de 2016 e do primeiro semestre de 2017. Os resultados foram relatados como percentuais, através do desenvolvimento de fórmulas para calcular cada indicador e, assim, estabelecer metas de acordo com as análises dos resultados.

No segundo semestre de 2017, foi elaborado um manual para agências transfusionais, através de consultas as normas brasileiras e internacionais (ANVISA - Agência Nacional de Vigilância Sanitária, MS - Ministério da Saúde, AABB American Association of Blood Banks) sobre as condutas hemoterápicas atuais. 


\section{RESULTADOS E DISCUSSÃO}

\subsection{Documentos elaborados pela Gestão da Qualidade}

\subsubsection{Organograma hierárquico}

O organograma é entendido como uma representação gráfica das relações hierárquicas entre os cargos na organização, ilustrando os níveis de autoridades e responsabilidades. Esta representação permite informar aos colaboradores, a organização da hierarquia e a divisão das atividades na instituição.

O organograma da AT havia sido elaborado em 2007 e sua última revisão foi realizada em 2011. Para a implantação da $G Q$ houve necessidade de sua atualização.

Na Figura 1, está representado o organograma atualizado:

Figura 1 - Organograma da AT-HUJM

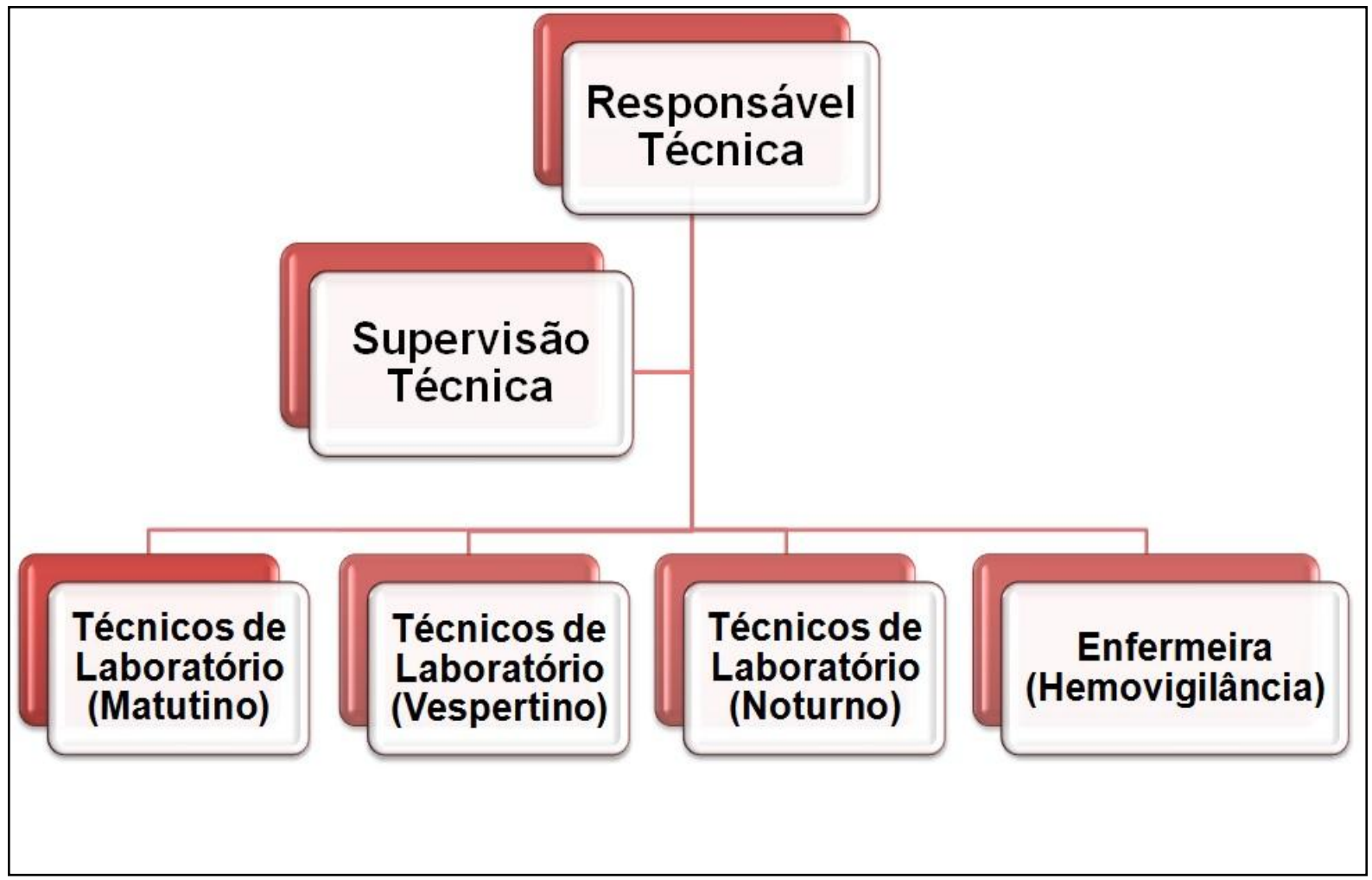

Fonte: resultados da pesquisa (2016). 
Em qualquer instituição é importante que os colaboradores conheçam a organização e sua estrutura hierárquica. Esse instrumento contribui com o alinhamento e conhecimento dos canais de comunicação, informando a quem os funcionários devem se referir. $O$ organograma também possui importante papel para os gestores, uma vez que ele ilustra claramente quais são as pessoas que estão sob sua supervisão. Ao implementar um organograma e definir as pessoas e posições que as mesmas ocupam na organização, é possível delas exigir as metas estabelecidas (GIRARDELLO, 2015).

\subsubsection{Documentos da qualidade}

Através da implantação da GQ na AT-HUJM, conseguiu-se a elaboração, revisão, e implementação dos documentos padronizados, denominados como Registros da Qualidade - RQ e Formulários de Registros - FR.

Os RQ, descritos na NBR ISO 9001:2015 como informação documentada, devem ser controlados pela organização para assegurar que estejam disponíveis e adequados para uso, onde e quando forem necessários.

A importância do estabelecimento e armazenamento dos registros está em comparar o desempenho perante os RQ (CARDOSO; LUZ, 2004). A existência de documentos padronizados de registro tem significativa importância para comprovar o que foi realizado. Esta comprovação é fundamental para sistemas de qualidade, pois de nada adianta serem executados procedimentos dentro das especificações exigidas, se os mesmos não forem evidenciados por meio de registros (GIRARDELLO, 2015). Diante disto, a AT-HUJM estabeleceu e implantou padrões para tais registros.

Os $\mathrm{RQ}$ foram elaborados com a finalidade de registrar, de modo padronizado, os controles de temperatura, de limpeza de ambientes e de equipamentos da AT-HUJM e demais registros específicos do setor. Para esses documentos, foi estabelecido um modelo padrão de cabeçalho, mostrado na Figura 2, e seu registro por um código que une as iniciais das palavras referentes à: Registros da Qualidade (RQ), Setor de Apoio Diagnóstico e Terapêutico (SADT) e 
Agência Transfusional (AT), seguidas por uma numeração que inclui o número do registro, o ano e a versão da revisão do documento.

Figura 2 - Modelo de cabeçalho padrão dos Registros da Qualidade da AT-HUJM

\begin{tabular}{|c|c|c|c|c|}
\hline \multirow{2}{*}{$\begin{array}{l}\text { HOSPTAL } \\
\text { LNIVERSTÁRIO } \\
\text { LULIO MULLER } \\
\text { EBSERH }\end{array}$} & \multicolumn{4}{|c|}{ REGISTROS DA QUALIDADE - AGÊNCIA TRANSFUSIONAL } \\
\hline & RQ/SADT-AT/001/2016/V.01 & $\begin{array}{c}\text { DATA APROVAÇÃO } \\
05 / 03 / 2016\end{array}$ & DATA REVISÃO & $\begin{array}{l}\text { Pág. } \\
1 / 1\end{array}$ \\
\hline \multicolumn{5}{|c|}{ Controle de Temperatura Ambiente - Sala de Preparo } \\
\hline
\end{tabular}

Fonte: resultados da pesquisa (2016).

Até o momento existem $12 \mathrm{RQ}$, conforme relação apresentada no Quadro 2. Esta padronização apresenta como vantagem, o registro padronizado de todas as informações necessárias e importantes, já que os formulários possuem os campos necessários para o registro das informações e dos responsáveis pelas ações. Antes da implantação da $G Q$, não havia um padrão para estes registros.

Quadro 2 - Relação dos Registros da Qualidade

\begin{tabular}{|c|c|}
\hline Número do $R Q$ & Título do $R Q$ \\
\hline RQ/SADT-AT/001/2016/V.01 & Controle de temperatura ambiente - Sala de preparo \\
\hline RQ/SADT-AT/002/2016/V.01 & $\begin{array}{l}\text { Controle de temperatura - Câmara de conservação de } \\
\text { Concentrado de Hemácias }\end{array}$ \\
\hline RQ/SADT-AT/003/2016/V.01 & $\begin{array}{l}\text { Controle de Temperatura - Freezer de armazenamento de } \\
\text { PFC e CRIO }\end{array}$ \\
\hline RQ/SADT-AT/004/2016/V.01 & $\begin{array}{l}\text { Controle de temperatura - Câmara de conservação de } \\
\text { Plaquetas }\end{array}$ \\
\hline RQ/SADT-AT/005/2016/V.01 & Controle de temperatura - Geladeira de reagentes \\
\hline RQ/SADT-AT/006/2016/V.01 & $\begin{array}{l}\text { Controle de temperatura - Banho-maria para descongelar } \\
\text { PFC }\end{array}$ \\
\hline RQ/SADT-AT/007/2016/V.01 & Controle de temperatura - Banho-maria para amostras \\
\hline RQ/SADT-AT/008/2016/V.01 & Registro de limpeza - Periodicidade diária \\
\hline RQ/SADT-AT/009/2016/V.01 & Registro de limpeza - Periodicidade semanal \\
\hline RQ/SADT-AT/010/2016/V.01 & Registro de limpeza - Periodicidade quinzenal \\
\hline RQ/SADT-AT/011/2016/V.01 & Registro de limpeza - Periodicidade mensal \\
\hline RQ/SADT-AT/012/2016/V.01 & Higienização terminal das salas da AT-HUJM \\
\hline
\end{tabular}

Fonte: resultados da pesquisa (2016). 
Os Formulários de Registros (FR) são documentos utilizados nos processos de trabalho da AT-HUJM. Eles foram criados e/ou formatados no novo padrão, a fim de organizar e facilitar os processos. A disponibilidade de informação eficiente e sistematizada, nas organizações que se propõem a adotar um sistema de gestão da qualidade, é condição fundamental para o alcance dos resultados pré-estabelecidos (OLIVEIRA, 2004).

A Figura 3 mostra que todos os FR possuem, no rodapé, um código para controle do documento, que está relacionado ao setor. Esse código se refere às iniciais das palavras Formulários de Registros (FR), Setor de Apoio Diagnóstico e Terapêutico (SADT), e Agência Transfusional (AT), além de seguir uma numeração sequencial relativa ao número do registro, o ano e a versão da revisão do documento.

Figura 3 - Modelo de rodapé padrão dos Formulários de Registros da AT-HUJM

Fonte: resultados da pesquisa (2016).

O Quadro 3 relaciona os 14 FR existentes até o momento.

O estabelecimento de documentos que permitem registrar informações também pode evitar a execução de procedimentos não conformes e, desta maneira, evitar o retrabalho. A gestão da qualidade prima pela simplificação dos processos (OLIVEIRA, 2004).

Quadro 3 - Relação dos Formulários de Registros

(continua)

\begin{tabular}{|c|c|}
\hline $\begin{array}{c}\text { Número do Formulário de } \\
\text { Registro }\end{array}$ & Título do Formulário de Registro \\
\hline FR/SADT-AT/001/2016/V.01 & Solicitação de Transfusão \\
\hline FR/SADT-AT/002/2016/V.01 & Ficha de Acompanhamento de transfusão \\
\hline FR/SADT-AT/003/2016/V.01 & Solicitação de transfusão de urgência \\
\hline FR/SADT-AT/004/2016/V.01 & Ficha de Receptor de hemocomponentes \\
\hline FR/SADT-AT/005/2016/V.01 & $\begin{array}{l}\text { Termo de Consentimento Livre e Esclarecido para } \\
\text { Receptores de Hemocomponentes }\end{array}$ \\
\hline FR/SADT-AT/006/2016/V.01 & $\begin{array}{l}\text { Termo de Consentimento Livre e Esclarecido para liberação } \\
\text { de sangue incompatível }\end{array}$ \\
\hline
\end{tabular}


(continuação)

\begin{tabular}{|c|c|}
\hline $\begin{array}{l}\text { Número do Formulário de } \\
\text { Registro }\end{array}$ & Título do Formulário de Registro \\
\hline FR/SADT-AT/007/2016/V.01 & Ficha de anexação de solicitação de transfusão \\
\hline FR/SADT-AT/008/2016/V.01 & $\begin{array}{l}\text { Ficha de envio de amostra para investigação imuno- } \\
\text { hematológica }\end{array}$ \\
\hline FR/SADT-AT/009/2016/V.01 & Solicitação de Hemocomponentes \\
\hline FR/SADT-AT/010/2016/V.01 & Lista de presença de instrutoria interna \\
\hline FR/SADT-AT/011/2016/V.01 & Controle de qualidade de reagentes \\
\hline FR/SADT-AT/012/2016/V.01 & Registro das validações de equipamentos \\
\hline FR/SADT-AT/013/2016/V.01 & Registro das calibrações periódicas de equipamentos \\
\hline FR/SADT-AT/014/2016/V.01 & Registro de intercorrências \\
\hline
\end{tabular}

Fonte: resultados da pesquisa (2016).

\subsection{Ações implantadas pela Gestão da Qualidade}

\subsubsection{Revisão da política da qualidade (missão, visão e valores)}

A definição da política da qualidade, missão, visão e valores da organização faz parte do processo de implantação da gestão da qualidade. Definir estes princípios pode auxiliar na tomada de decisões, bem como no norteamento das ações das organizações.

A Portaria de Consolidação MS n 05, de 03 de outubro de 2017, de acordo com o anexo IV, estabelece no seu Art. 238, parágrafo único, que o "serviço de hemoterapia definirá e divulgará sua missão e sua política da qualidade, considerando os requisitos dos usuários" (BRASIL, 2017). Com base nesta exigência, como ação da Gestão da Qualidade, a Direção Geral, a Direção Técnica e a equipe da AT-HUJM definiram a política da qualidade e revisaram os conceitos de missão, visão e valores, que passaram a ser:

a. Política da Qualidade:

- Garantir a qualidade da transfusão no hospital;

- Atender as necessidades dos pacientes a serem transfundidos; 
- Desenvolver ações contínuas de treinamento e atualização da equipe;

- Estimular os colaboradores para a melhoria dos processos realizados.

b. Missão:

- Transfusão segura de hemocomponentes aos pacientes atendidos no HUJM, com elevados padrões de qualidade, visando maior segurança transfusional a todos os envolvidos, criando, assim, uma relação de confiança, segurança no acolhimento de pacientes e familiares.

c. Visão:

- Tornar um serviço de referência no segmento hemoterápico, pela qualidade dos serviços prestados, respeitando os princípios de integralidade, universalidade, equidade e legislações específicas.

d. Valores:

- Ética e credibilidade;

- Prezar pela saúde e atendimento humanizado aos clientes;

- Responsabilidade social;

- Respeito ao meio ambiente;

- Valorizar os recursos humanos e trabalho em equipe;

- Investir em educação continuada;

- Buscar, permanentemente, a satisfação do cliente.

\subsubsection{Descrição dos Macroprocessos}

De acordo com Netto (2004, p. 2), a gestão por macroprocessos,

...contempla uma coleção de atividades controladas e interligadas que tomam uma ou mais entradas, utilizam recursos e criam uma saída que agregue valor ao cliente, tendo por objetivo básico, permitir que a organização forneça valor aos seus clientes, estabelecendo objetivos e metas e monitorando o seu desempenho. Tal visão também traria os benefícios de propiciar maior integração da instituição e provocar mudanças organizacionais que direcionem a um mais alto nível de desempenho. 
Com a implantação da $G Q$, a descrição dos macroprocessos da AT, mostrados na Figura 4, foi de grande importância para a equipe e para outros setores do hospital entender como o trabalho deve ser realizado, como as atividades estão vinculadas aos processos, incluindo os relacionamentos internos entre clientefornecedor, por meio dos quais são produzidos os produtos e serviços.

Figura 4 - Macroprocesso da AT-HUJM

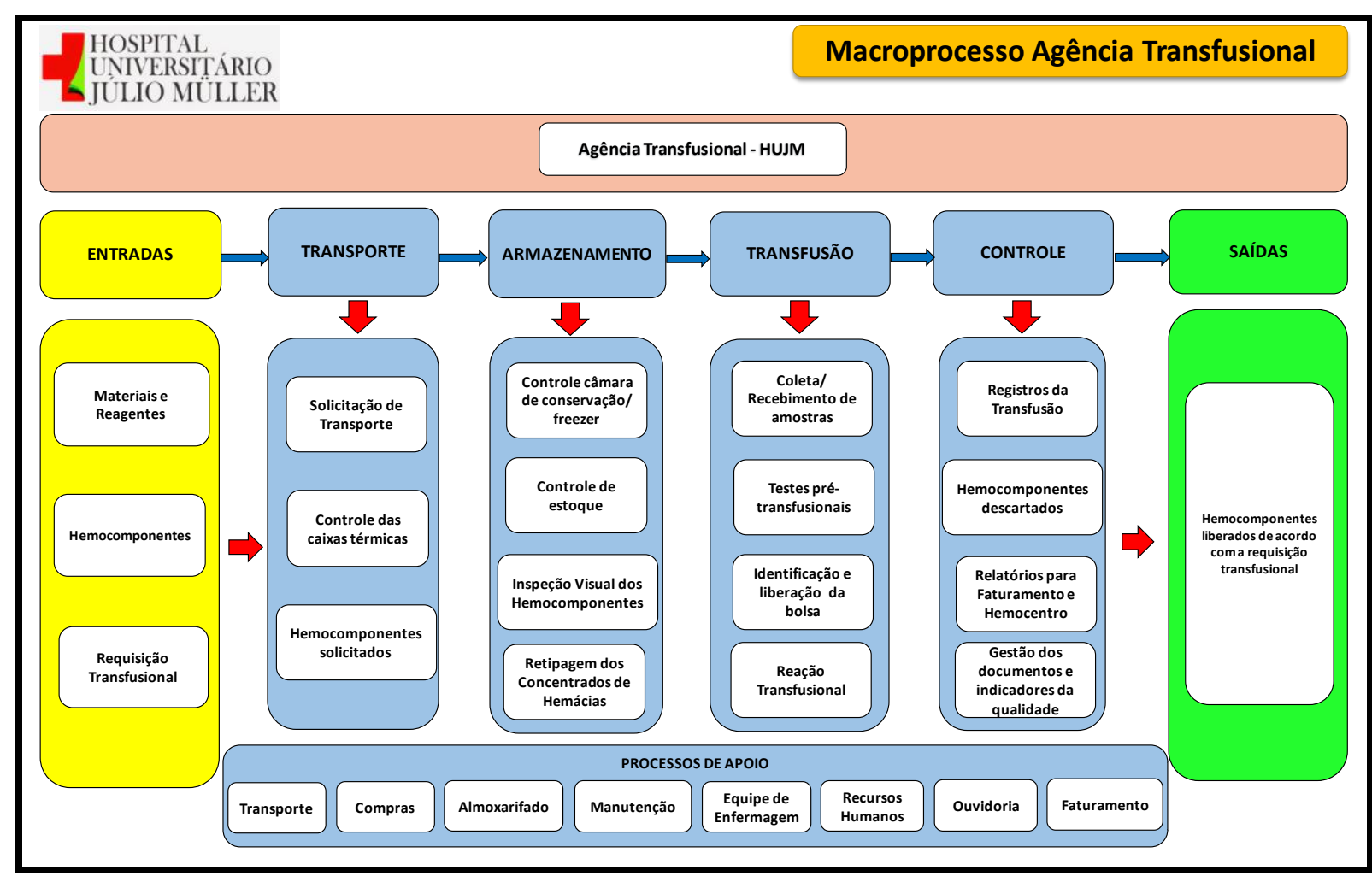

Fonte: a autora (2016).

\subsubsection{Gerenciamento e padronização dos documentos}

Os Procedimentos Operacionais Padrão - POP's são documentos essenciais nos $S G Q$, sendo definidos como "procedimentos escritos e autorizados, introduzidos nas rotinas de trabalho, que fornecem instruções detalhadas para a realização de atividades específicas" (BRASIL, 2014).

Estes documentos possuem a finalidade de obter, de forma padronizada, os resultados esperados por cada atividade realizada e, também, de contribuir para diminuição da ocorrência de erros no processo de trabalho. Com isso, a sua 
existência e o seu gerenciamento contribuem para a garantia da qualidade dos produtos e serviços. Conforme preconizado pela Portaria de Consolidação 05, em seu artigo 18, "cada serviço de hemoterapia manterá um conjunto de procedimentos operacionais, técnicos e administrativos, para cada área técnica e administrativa" (BRASIL, 2017).

Os POP's devem descrever, de forma detalhada, todos os processos da organização, sendo escritos e revisados pela área correspondente e, posteriormente, aprovados pela direção do serviço. A periodicidade de suas revisões é anual, conforme estabelecido no artigo 18, § 5을 da Portaria de Consolidação 05.

A AT-HUJM já disponibilizava, antes da implantação da Gestão da Qualidade, procedimentos operacionais para a maioria das atividades realizadas, porém, ainda não estavam estabelecidos um padrão e um processo para gerenciamento destes documentos.

Com a GQ, foi estabelecido um padrão para os POP's, como mostra a Figura 5, sendo a supervisão técnica da AT-HUJM orientada a segui-lo na formatação dos POP's, bem como a elaborar os ainda não descritos.

Figura 5 - Modelo de capa padrão dos Procedimentos Operacionais da AT- HUJM

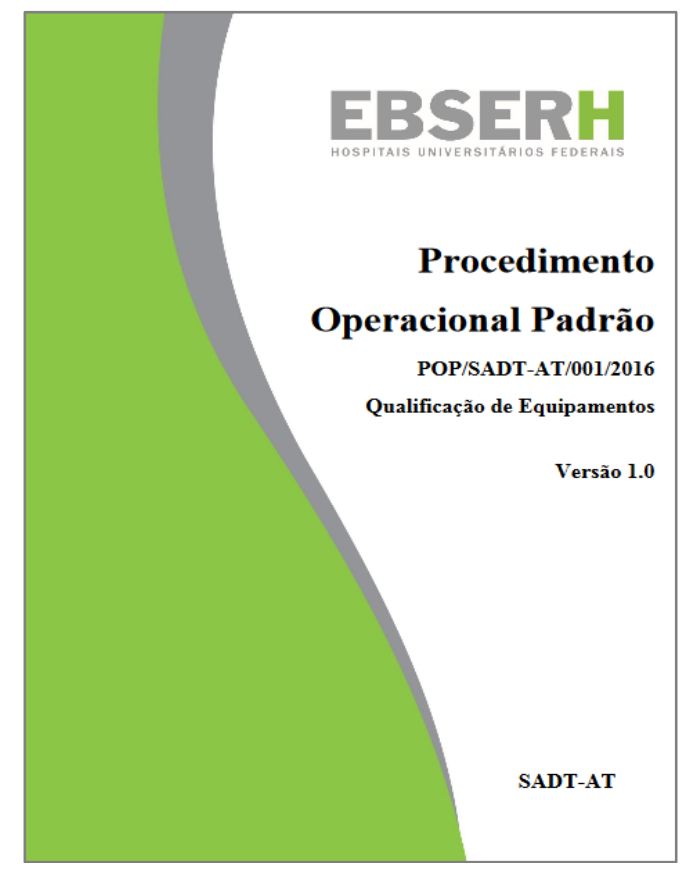

Fonte: resultados da pesquisa (2016).

$\mathrm{Na}$ capa do modelo, existe um campo que permite incluir um código, cuja padronização facilita o controle e o gerenciamento dos documentos relacionados ao 
setor. Este código se refere às iniciais das palavras "Procedimento Operacional Padrão" (POP), "Setor Apoio Diagnóstico Terapêutico" (SADT) e "Agência Transfusional" (AT), seguidas de uma numeração sequencial, referente ao número do registro e ao ano da criação ou revisão do documento. O Quadro 4 relaciona os 11 POP existentes até o momento.

Quadro 4 - Relação dos Procedimentos Operacionais Padrão

\begin{tabular}{|c|c|}
\hline $\begin{array}{c}\text { Código do Procedimento Operacional } \\
\text { Padrão }\end{array}$ & Título do Procedimento Operacional Padrão \\
\hline POP/SADT-AT/001/2016 Versão 1 & Qualificação de equipamentos \\
\hline POP/SADT-AT/002/2016 Versão 1 & Limpeza e desinfecção de superfícies \\
\hline POP/SADT-AT/003/2016 Versão 1 & Indicação de hemocomponentes especiais \\
\hline POP/SADT-AT/004/2016 Versão 1 & $\begin{array}{c}\text { Preparação de hemocomponentes para } \mathrm{RN} \text { e crianças } \\
\text { até } 4 \text { meses }\end{array}$ \\
\hline POP/SADT-AT/005/2016 Versão 1 & $\begin{array}{c}\text { Administração de hemocomponentes em RN e crianças } \\
\text { até } 4 \text { meses }\end{array}$ \\
\hline POP/SADT-AT/006/2016 Versão 1 & Exsanguineotransfusão \\
\hline POP/SADT-AT/007/2016 Versão 1 & Controle de qualidade interno de reagentes \\
\hline POP/SADT-AT/008/2016 Versão 1 & Prática do ato transfusional \\
\hline POP/SADT-AT/009/2016 Versão 1 & Provas pré-transfusionais \\
\hline POP/SADT-AT/010/2016 Versão 1 & $\begin{array}{c}\text { Solicitação de transfusão em rotina, emergência e } \\
\text { urgência }\end{array}$ \\
\hline POP/SADT-AT/011/2016 Versão 1 & Transfusão em neonatos e crianças até 4 meses \\
\hline
\end{tabular}

Fonte: resultados da pesquisa (2016).

Os protocolos são definidos como "conjunto de regras escritas, definidas para a realização de determinado procedimento" (BRASIL, 2014). Têm como finalidade fornecer ao profissional da saúde a instrumentalização necessária para sua atuação profissional com segurança, autonomia e compromisso ético. O protocolo é essencial para gerenciamento do cuidado que envolve tomada de decisões e etapas processuais em saúde, contribuindo para a legitimidade, autonomia profissional e segurança na assistência a ser prestada. É uma ferramenta da prática em saúde que deve ser flexível e atualizada.

Assim como para os procedimentos operacionais, foi estabelecido um padrão para estes documentos. Nas capas, como mostra a Figura 6 , existe um campo para inclusão de um código de controle do documento, que está relacionado 
ao setor. Este código segue a mesma lógica já explicada, anteriormente, para os documentos RQ e POP.

Figura 6 - Modelo de capa padrão dos Protocolos Clínicos da AT- HUJM

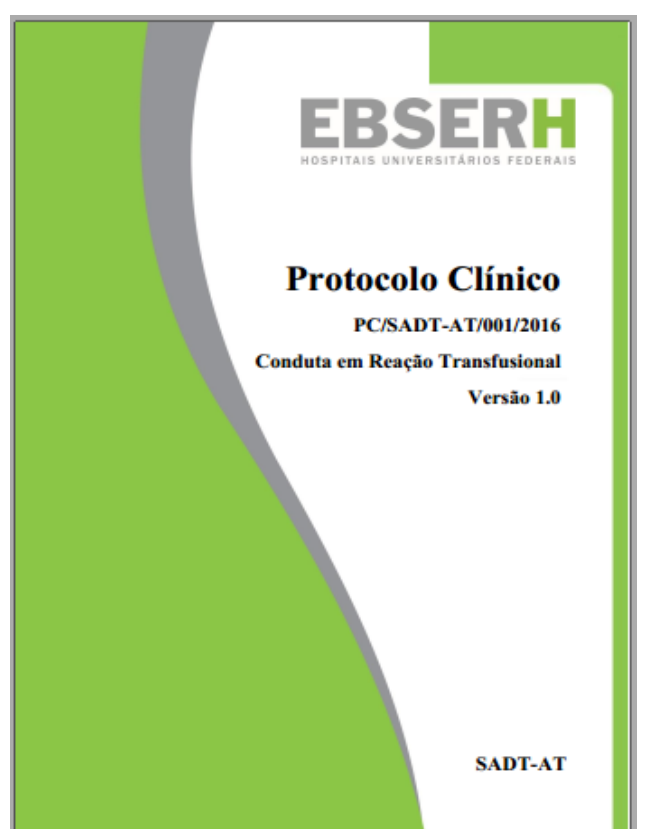

Fonte: resultados da pesquisa (2016).

Até o momento, foram criados 04 protocolos, relacionados no Quadro 5.

Foram criados, também, Manuais (MN) e, do mesmo modo, foi estabelecido um padrão para estes documentos, com uma lógica semelhante à já descrita anteriormente, para os RQ, POP e PC. A Figura 7 mostra a capa de um MN.

Quadro 5 - Relação dos Protocolos Clínicos

\begin{tabular}{|cc|}
\hline Código do Protocolo Clínico & Título do Protocolo Clínico \\
PC/SADT-AT/001/2016 Versão 1 & Conduta em reação transfusional \\
PC/SADT-AT/002/2016 Versão 1 & Indicação de transfusão sanguínea \\
PC/SADT-AT/003/2016 Versão 1 & Transfusão maciça \\
PC/SADT-AT/004/2016 Versão 1 & Transfusão em pacientes alo-imunizados \\
\hline
\end{tabular}

Fonte: resultados da pesquisa (2016). 
Figura 7 - Modelo de capa padrão dos Manuais da AT-HUJM

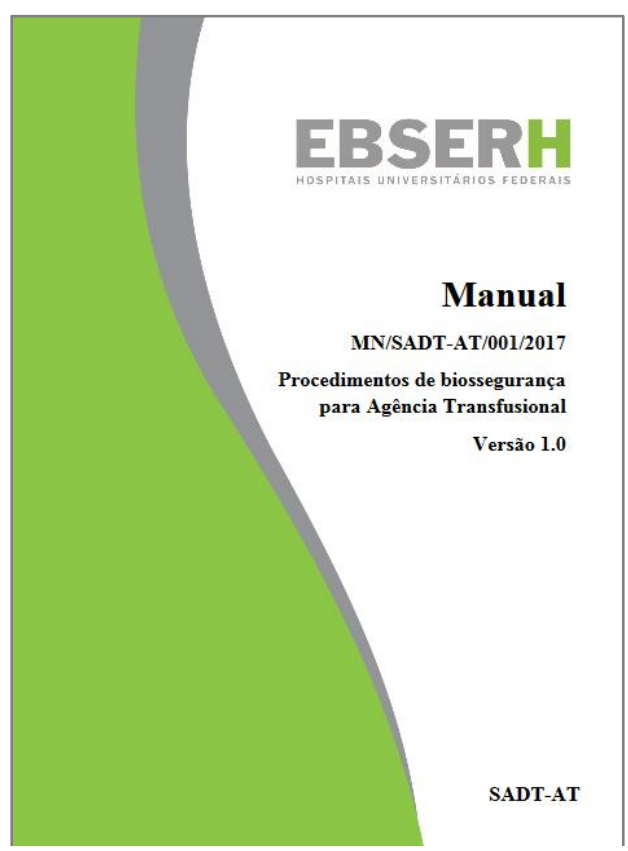

Fonte: resultados da pesquisa (2016).

Até o momento, existem 02 Manuais, conforme relação apresentada no Quadro 6.

Quadro 6 - Relação dos Manuais

\begin{tabular}{|cc|}
\hline Código do Manual & Título do Manual \\
MN/SADT-AT/001/2017 Versão 1 & Procedimentos de biossegurança para agência \\
& transfusional \\
MN/SADT-AT/002/2017 Versão 1 & Manual de transfusão para a equipe de enfermagem \\
\hline
\end{tabular}

Fonte: resultados da pesquisa (2017).

Todos os arquivos digitais destes documentos ficam sob a coordenação da Gestão da Qualidade e somente são disponibilizados para revisão anual ou para alterações necessárias, gerando, desta forma, documentos bem controlados, o que evita a utilização de documentos desatualizados e, consequentemente, a execução de atividades fora do padrão estabelecido.

A impressão, os registros e o controle das revisões dos procedimentos operacionais, protocolos clínicos e manuais, fazem parte do gerenciamento dos documentos da GQ. Essa ação possibilitou um maior controle, organização e padronização dos documentos, garantindo a realização de suas revisões, quando 
necessário, no prazo preconizado pela legislação vigente e a utilização, sempre, de documentos revisados.

\subsubsection{Tratamento de não conformidades}

O artigo 240 da Portaria do MS 05, preconiza a criação de processo para identificação, investigação e análise dos desvios, com proposição de ações corretivas e verificação da eficácia das ações, em serviço de hemoterapia (BRASIL, 2017). A Resolução RDC ANVISA n 34, de 11 de junho de 2014, em seu Artigo 9º, também exige o tratamento das não conformidades, estabelecendo que todo serviço de hemoterapia, que realize atividades do ciclo do sangue, deve ter um sistema de gestão da qualidade que inclua o tratamento de não conformidades e a adoção de medidas corretivas e preventivas, visando à implementação do gerenciamento da qualidade (BRASIL, 2014).

Considerando o preconizado pelas normas citadas, deve-se realizar o registro e o tratamento de toda situação não conforme, também conhecida como intercorrências. Diante disto, foi elaborado, um formulário para tais situações, o FR/SADT-AT/014/2016/V.01 - Intercorrências, tendo como referência os itens do relatório de não-conformidades do Hemocentro-RP, observado durante o benchmarking. O formulário possui espaços para se descrever a situação não conforme, citação das medidas preventivas e corretivas adotadas, bem como anotação das anuências dos envolvidos e da direção geral e técnica da AT-HUJM.

Todas as intercorrências são registradas com uma numeração sequencial. A gestão das não conformidades possibilita a análise das causas e a proposição de ações corretivas e preventivas, ajudando a melhoria contínua dos processos de trabalho. Estes registros são importantes, já que auxiliam na busca de soluções, além de gerarem momentos de discussão dos problemas entre a equipe, fazendo com que ocorra o envolvimento dos colaboradores e que os mesmos se sintam comprometidos com o processo de busca de soluções e de melhoria contínua dos serviços prestados. 


\subsubsection{Realização de auditorias}

De acordo com a Norma Regulamentadora Brasileira (NBR) ISO 9000:2005, a auditoria é uma atividade de coleta de informações para verificar o atendimento aos requisitos especificados, procurando evidências de conformidades, avaliando as necessidades de ações corretivas ou de aperfeiçoamento, não devendo ser confundidas com atividades de supervisão ou inspeção. É importante ressaltar ainda que a auditoria não tem o objetivo de identificar os culpados pela não conformidade e sim, propor soluções para que sejam eliminadas.

De acordo com a forma de intervenção, a auditoria pode ser classificada em: interna e externa. A auditoria interna é realizada por elementos da própria instituição, devidamente informados e treinados. A auditoria externa é realizada por profissionais que não pertencem à instituição, estipulados especificamente para a auditoria (KURCGANT, 1991).

A implantação de auditorias internas é uma exigência da legislação hemoterápica vigente (BRASIL, 2017), com o objetivo de verificar o cumprimento dos requisitos pré-definidos. Seus resultados são registrados, discutidos e revisados pela área auditada com proposição de ações corretivas e preventivas que são avaliadas e aprovadas pela supervisão do serviço de hemoterapia.

Considerando que a auditoria externa permite observar o cenário, verificar as evidências de oportunidades de melhoria nos processos desenvolvidos e, por meio de análise dos resultados, propor mecanismos de ação para desencadear a Garantia da Qualidade nos processos (BITTAR, 2004).

Em 2016, foi realizada uma auditoria externa na AT-HUJM, utilizando o roteiro de visita proposto pelo Ministério da Saúde. A equipe avaliadora constituiu-se de um auditor do Ministério da Saúde e três funcionários do Hemocentro Coordenador de Mato Grosso (MT-Hemocentro).

O método de avaliação ocorreu de acordo com os pressupostos orientados no curso de formação de auditores do PNQH (Programa Nacional de Qualificação da Hemorrede), tendo cada avaliador o papel de educador, em uma abordagem formal, imparcial e respeitosa. Efetivadas a avaliação e a identificação de fatos, a equipe de avaliadores se reuniu e, por consenso, elaborou o relatório final com suas conclusões e recomendações. 
O Quadros de 07 a 12 descrevem em suas três colunas, as não conformidades apontadas na auditoria, o plano de ação traçado para solução desses itens e sua situação atual.

Quadro 7 - Não conformidades referentes à coleta de amostras e cadastro de pacientes

\begin{tabular}{|c|c|c|}
\hline Itens apontados em 2016 & Plano de ação realizado & Situação em 2017 \\
\hline $\begin{array}{l}\text { Ausência de POP } \\
\text { impressos. }\end{array}$ & $\begin{array}{l}\text { Providenciar as cópias } \\
\text { impressas dos POP } \\
\text { finalizados em versão } \\
\text { eletrônica. Terminar a } \\
\text { revisão dos POP e } \\
\text { publicar os mesmos na } \\
\text { intranet. }\end{array}$ & $\begin{array}{l}\text { Ação Concluída. Todos os POP } \\
\text { foram revisados e encontram-se } \\
\text { disponíveis na Agência impressos e } \\
\text { na intranet (versão eletrônica). }\end{array}$ \\
\hline $\begin{array}{l}\text { Falta de registro } \quad \text { de } \\
\text { treinamentos } \\
\text { procedimentos de coleta e } \\
\text { transfusão. }\end{array}$ & $\begin{array}{l}\text { Planejar treinamento da } \\
\text { equipe da AT referente ao } \\
\text { procedimento de coleta. } \\
\text { Capacitar a equipe de } \\
\text { enfermagem para a } \\
\text { transfusão } \\
\text { hemocomponentes. }\end{array}$ & $\begin{array}{l}\text { Ação Concluída. Foi realizado o } \\
\text { treinamento da equipe da AT sobre } \\
\text { coleta de amostras e capacitação da } \\
\text { equipe de enfermagem (técnicos e } \\
\text { enfermeiros) sobre instalação de } \\
\text { hemocomponentes, sendo que a } \\
\text { nova rotina de transfusão pela } \\
\text { equipe de enfermagem entrou em } \\
\text { vigor a partir de Junho/2017. }\end{array}$ \\
\hline $\begin{array}{l}\text { Falta de padronização na } \\
\text { identificação dos tubos } \\
\text { para coleta de amostras do } \\
\text { receptor e nas etiquetas } \\
\text { fixadas nas bolsas dos } \\
\text { hemocomponentes a ser } \\
\text { transfundido, dificultando a } \\
\text { rastreabilidade. }\end{array}$ & $\begin{array}{l}\text { Realizar a confecção de } \\
\text { etiquetas padronizadas } \\
\text { para identificação das } \\
\text { amostras dos pacientes e } \\
\text { dos hemocomponentes } \\
\text { enviados aos mesmos. }\end{array}$ & $\begin{array}{l}\text { Ação Concluída. } \\
\text { padronizadas etiquetas impressam } \\
\text { para identificação das amostras } \\
\text { coletadas e implantação de um } \\
\text { sistema eletrônico de impressão de } \\
\text { etiquetas para identificação dos } \\
\text { hemocomponentes. }\end{array}$ \\
\hline
\end{tabular}

Fonte: resultados da pesquisa (2017).

Quadro 8 - Não conformidades referentes à imuno-hematologia do receptor

\begin{tabular}{|c|c|c|}
\hline Itens apontados em 2016 & Plano de ação realizado & Situação em 2017 \\
\hline $\begin{array}{lll}\begin{array}{l}\text { Ausência } \\
\text { impressos }\end{array} & \text { de } & \text { POP } \\
\end{array}$ & $\begin{array}{l}\text { Providenciar as cópias } \\
\text { impressas dos POP finalizados } \\
\text { em versão eletrônica. Terminar } \\
\text { a revisão dos POP e publicar } \\
\text { os mesmos na intranet. }\end{array}$ & $\begin{array}{l}\text { Ação Concluída. Todos os POP } \\
\text { foram revisados e encontram-se } \\
\text { disponíveis na Agência impressos } \\
\text { e na intranet (versão eletrônica). }\end{array}$ \\
\hline $\begin{array}{l}\text { Falta de monitoramento e } \\
\text { registro de temperatura de } \\
\text { alguns equipamentos }\end{array}$ & $\begin{array}{l}\text { Planejar treinamento da equipe } \\
\text { da Agência Transfusional } \\
\text { referente ao procedimento de } \\
\text { monitoramento e registros de } \\
\text { temperaturas dos } \\
\text { equipamentos e atualizar os } \\
\text { formulários de registros. }\end{array}$ & $\begin{array}{l}\text { Ação Concluída. Os formulários } \\
\text { de registros de temperatura foram } \\
\text { atualizados e disponibilizados. Foi } \\
\text { realizado treinamento da equipe } \\
\text { da Agência sobre a importância do } \\
\text { procedimento de monitoramento e } \\
\text { registros de temperaturas dos } \\
\text { equipamentos e do ambiente. }\end{array}$ \\
\hline
\end{tabular}


(continuação)

\begin{tabular}{|c|c|c|}
\hline $\begin{array}{c}\text { Itens apontados em } \\
2016\end{array}$ & Plano de ação realizado & Situação em 2017 \\
\hline $\begin{array}{l}\text { Falta do reagente controle } \\
\text { de Rh para técnica em } \\
\text { tubo e ausência na rotina } \\
\text { a realização do teste de } \\
\text { Coombs Direto para } \\
\text { Recém-Nascido }\end{array}$ & $\begin{array}{l}\text { Providenciar a compra do } \\
\text { reagente controle de Rh } \\
\text { (técnica em tubo); Implantar } \\
\text { na rotina a realização do teste } \\
\text { de Coombs Direto como } \\
\text { exame pré-transfusional para } \\
\text { Recém Nascidos. }\end{array}$ & $\begin{array}{l}\text { Ação Concluída. A compra do } \\
\text { reagente foi realizada, estando o } \\
\text { mesmo disponível na agência; E } \\
\text { o teste de Coombs Direto foi } \\
\text { implantado na rotina pré- } \\
\text { transfusional para Recém } \\
\text { Nascidos. }\end{array}$ \\
\hline $\begin{array}{lr}\text { Ausência de registro das } \\
\text { não conformidades e } \\
\text { ausência } & \text { de } \\
\text { gerenciamento dos } & \text { desultados do Controle de } \\
\text { Qualidade Externo (CQE) }\end{array}$ & 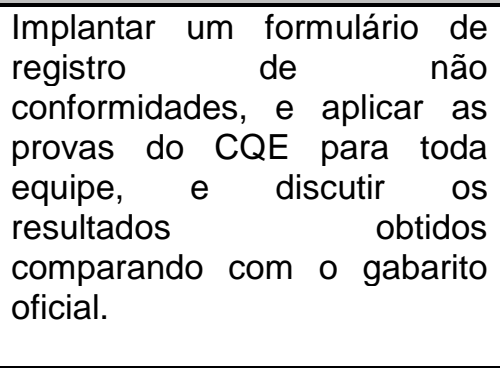 & $\begin{array}{l}\text { Ação em andamento: } \\
\text { formulário de registro das não } \\
\text { conformidades foi elaborado e } \\
\text { está sendo implantado. } \\
\text { Ação Concluída. As provas do } \\
\text { CQE estão sendo } \\
\text { disponibilizadas para a equipe, e } \\
\text { seus resultados são discutidos e } \\
\text { registrados em reunião. }\end{array}$ \\
\hline
\end{tabular}

Fonte: resultados da pesquisa (2017).

Quadro 9 - Não conformidades referentes à transfusão

\begin{tabular}{|c|c|c|}
\hline Itens apontados em 2016 & Plano de ação realizado & Situação em 2017 \\
\hline $\begin{array}{l}\text { Ausência de } \text { POP } \\
\text { impressos sobre indicação, } \\
\text { uso e descarte de } \\
\text { hemocomponentes }\end{array}$ & $\begin{array}{lcr}\text { Providenciar } & \text { as } & \text { cópias } \\
\text { impressas } & \text { dos } & \text { POP } \\
\text { finalizados } & \text { em versão } \\
\text { eletrônica. } & \text { Terminar a } \\
\text { revisão dos } & \text { POP e publicar } \\
\text { os mesmos na intranet. }\end{array}$ & $\begin{array}{l}\text { Ação Concluída. Todos os POP } \\
\text { foram revisados e encontram-se } \\
\text { disponíveis na Agência impressos e } \\
\text { na intranet (versão eletrônica). }\end{array}$ \\
\hline $\begin{array}{l}\text { Ausência de registro de } \\
\text { sinais vitais pré e pós } \\
\text { Transfusional }\end{array}$ & $\begin{array}{l}\text { Implantar a Ficha de } \\
\text { Acompanhamento de } \\
\text { Transfusão (em confecção), } \\
\text { que ficará no prontuário do } \\
\text { paciente, a qual contempla o } \\
\text { registro dos sinais vitais no } \\
\text { início, durante e no final da } \\
\text { transfusão. }\end{array}$ & $\begin{array}{l}\text { Ação Concluída. A Ficha de } \\
\text { Acompanhamento de Transfusão foi } \\
\text { implantada através de treinamento da } \\
\text { equipe da agência e da enfermagem, } \\
\text { e o acompanhamento e registro dos } \\
\text { sinais vitais estão sendo realizado. }\end{array}$ \\
\hline $\begin{array}{ll}\text { Ausência de registro de } \\
\text { horário de saída } & \text { do } \\
\text { hemocomponente } & \text { da } \\
\text { agência e registro } & \text { da } \\
\text { temperatura } & \text { de } \\
\text { recebimento } & \text { de } \\
\text { hemocomponentes } & \\
\end{array}$ & $\begin{array}{l}\text { Implantar nova rotina de } \\
\text { registro do horário de saída } \\
\text { do hemocomponente da } \\
\text { agência e treinar a equipe } \\
\text { para registrar a temperatura } \\
\text { no recebimento dos } \\
\text { hemocomponentes. }\end{array}$ & $\begin{array}{l}\text { Ação Concluída. Foi implantada a } \\
\text { Ficha de Acompanhamento de } \\
\text { Transfusão em que se registra a saída } \\
\text { da bolsa da agência e a entrega à } \\
\text { equipe de enfermagem. Foi realizado } \\
\text { treinamento do registro de } \\
\text { temperatura no recebimento. }\end{array}$ \\
\hline
\end{tabular}

Fonte: resultados da pesquisa (2017). 
Quadro 10 - Não conformidades referentes à garantia da qualidade

\begin{tabular}{|c|c|c|}
\hline $\begin{array}{c}\text { Itens apontados em } \\
2016\end{array}$ & Plano de ação realizado & Situação em 2017 \\
\hline \begin{tabular}{lr}
\multicolumn{2}{c}{ Ausência de sistema } \\
de gestão & da \\
qualidade & e \\
indicadores. &
\end{tabular} & $\begin{array}{l}\text { Buscar auxílio dos } \\
\text { profissionais e da direção } \\
\text { do hospital para implantar } \\
\text { a GQ e o uso de } \\
\text { indicadores na AT. }\end{array}$ & $\begin{array}{l}\text { Ação em andamento. A agência está na } \\
\text { fase final da implantação de gestão da } \\
\text { qualidade e de indicadores. }\end{array}$ \\
\hline $\begin{array}{l}\text { Registros de } \\
\text { auditorias internas }\end{array}$ & $\begin{array}{l}\text { Planejar um cronograma } \\
\text { anual para realização de } \\
\text { auditorias internas. }\end{array}$ & $\begin{array}{l}\text { Ação em andamento: em processo de } \\
\text { definição e treinamento dos auditores, } \\
\text { planejamento da data da próxima auditoria } \\
\text { interna e escolha do roteiro a ser aplicado. }\end{array}$ \\
\hline $\begin{array}{lr}\text { Ausência } & \text { de } \\
\text { validação } & \text { dos } \\
\text { processos } & \text { e } \\
\text { equipamentos } & \end{array}$ & $\begin{array}{l}\text { Providenciar a validação } \\
\text { dos processos e } \\
\text { equipamentos. }\end{array}$ & $\begin{array}{l}\text { Ação em andamento: processos como, } \\
\text { transporte de hemocomponentes estão } \\
\text { em fase de validação; os equipamentos } \\
\text { estão sendo validados pela engenharia } \\
\text { clínica do hospital. A técnica em gel e } \\
\text { controle de qualidade interno já foram } \\
\text { validados. }\end{array}$ \\
\hline \begin{tabular}{lr}
\multicolumn{2}{l}{ Sistema de ouvidoria } \\
do Hospital para \\
reclamações \\
sugestões & dos \\
usuários &
\end{tabular} & $\begin{array}{lcrr}\text { Solicitar } & \text { ao } & \text { setor } & \text { de } \\
\text { ouvidoria } & \text { os } & \text { resultados } \\
\text { obtidos } & \text { em } & 2016 & \text { e } \\
\text { planejar } & \text { pesquisa } & \text { em } \\
2017 . & & & \end{array}$ & $\begin{array}{l}\text { Ação em andamento: em julho de } 2017 \\
\text { foram divulgados os resultados da } \\
\text { pesquisa de satisfação dos usuários do } \\
\text { hospital. A agência transfusional irá } \\
\text { solicitar à ouvidoria uma pesquisa } \\
\text { específica aos pacientes transfundidos. }\end{array}$ \\
\hline $\begin{array}{l}\text { Ausência de registros } \\
\text { que permitam a } \\
\text { rastreabilidade }\end{array}$ & $\begin{array}{l}\text { Providenciar formulários } \\
\text { de registros que garantam } \\
\text { a rastreabilidade dos } \\
\text { pacientes transfundidos. }\end{array}$ & $\begin{array}{l}\text { Ação Concluída. Foi implantada a Ficha } \\
\text { do Paciente (com histórico das } \\
\text { transfusões, que fica guardada na AT), e a } \\
\text { Ficha de Acompanhamento de Transfusão } \\
\text { (registram-se os dados da bolsa, horário, } \\
\text { sinais vitais, responsáveis pela entrega e } \\
\text { instalação, que fica; anexada ao } \\
\text { prontuário do paciente). }\end{array}$ \\
\hline $\begin{array}{l}\text { Ausência de registros } \\
\text { reuniões do Comitê } \\
\text { Transfusional }\end{array}$ & $\begin{array}{llr}\text { Providenciar cópia } & \text { de } \\
\text { atas das } & \text { reuniões } & \text { do } \\
\text { comitê, } & \text { planejar } & \text { e } \\
\text { executar } & \text { reuniões } & \text { de } \\
2017 . & & \end{array}$ & $\begin{array}{l}\text { Ação Concluída. As cópias das atas e } \\
\text { listas de presença das reuniões realizadas } \\
\text { estão sendo arquivadas em uma pasta. }\end{array}$ \\
\hline
\end{tabular}

Fonte: resultados da pesquisa (2017).

Quadro 11 - Não conformidades referentes à estrutura física e instalações

(continua)

\begin{tabular}{|l|l|l|}
\hline Itens apontados em 2016 & \multicolumn{1}{|c|}{ Plano de ação realizado } & \multicolumn{1}{c|}{ Situação em 2017 } \\
\hline $\begin{array}{l}\text { Ausência de alvará } \\
\text { sanitário }\end{array}$ & $\begin{array}{l}\text { Providenciar os requisitos } \\
\text { necessários para obtenção do } \\
\text { alvará sanitário do hospital. }\end{array}$ & $\begin{array}{l}\text { Ação Concluída. O alvará sanitário } \\
\text { foi expedido em 10/08/2017 pela } \\
\text { prefeitura de Cuiabá. }\end{array}$ \\
\hline $\begin{array}{l}\text { Fluxo inadequado, acesso } \\
\text { pelo banheiro; e falta de } \\
\text { sinalização. }\end{array}$ & $\begin{array}{l}\text { Solicitar urgente a mudança de } \\
\text { acesso à AT e fazer placas de } \\
\text { sinalização. }\end{array}$ & $\begin{array}{l}\text { Ação Concluída. Foi colocada uma } \\
\text { porta no corredor para melhor } \\
\text { acesso à agência e foram } \\
\text { instaladas placas de sinalização. }\end{array}$ \\
\hline $\begin{array}{l}\text { Não evidenciado registros } \\
\text { de controle de vetores. }\end{array}$ & $\begin{array}{l}\text { Providenciar a cópia dos dos } \\
\text { registros citados. }\end{array}$ & $\begin{array}{l}\text { Ação Concluída. As cópias do } \\
\text { Controle Integrado de Insetos em } \\
\text { toda a área interna e externa } \\
\text { estão sendo arquivadas. }\end{array}$ \\
\hline
\end{tabular}


(continuação)

\begin{tabular}{|l|l|l|}
\hline \multicolumn{1}{|c|}{$\begin{array}{c}\text { Itens apontados em } \\
\text { 2016 }\end{array}$} & \multicolumn{1}{|c|}{ Plano de ação realizado } & \multicolumn{1}{c|}{ Situação em 2017 } \\
\hline $\begin{array}{l}\text { Ausência do Plano de } \\
\text { Gerenciamento de } \\
\text { Resíduos de Serviços de } \\
\text { Saúde (PGRSS) }\end{array}$ & $\begin{array}{l}\text { Providenciar a confecção do do } \\
\text { PGRSS para todo hospital. }\end{array}$ & $\begin{array}{l}\text { Ação Concluída. O PGRSS foi } \\
\text { elaborado e encontra-se } \\
\text { disponível, na AT impresso e na } \\
\text { intranet em versão eletrônica. }\end{array}$ \\
\hline $\begin{array}{l}\text { Inexistência de POP de } \\
\text { biossegurança }\end{array}$ & $\begin{array}{l}\text { Providenciar a confecção do } \\
\text { mesmo. }\end{array}$ & $\begin{array}{l}\text { Ação Concluída. Foi elaborado } \\
\text { um manual de biossegurança } \\
\text { que se encontra disponível, na }\end{array}$ \\
& & $\begin{array}{l}\text { AT impresso e na intranet em } \\
\text { versão eletrônica. }\end{array}$ \\
\hline
\end{tabular}

Fonte: resultados da pesquisa (2017).

Quadro 12 - Não conformidades referentes às informações gerais

\begin{tabular}{|c|c|c|}
\hline $\begin{array}{c}\text { Itens apontados em } \\
2016\end{array}$ & Plano de ação realizado & Situação em 2017 \\
\hline $\begin{array}{l}\text { Não evidenciado } \\
\text { organograma da } \\
\text { Agência } \\
\text { Transfusional. }\end{array}$ & $\begin{array}{l}\text { Providenciar a atualização do } \\
\text { organograma e impressão do } \\
\text { mesmo. }\end{array}$ & $\begin{array}{l}\text { Ação Concluída. O organograma foi } \\
\text { atualizado e impresso, ficando disponível } \\
\text { na agência. }\end{array}$ \\
\hline $\begin{array}{l}\text { Ausência de registros } \\
\text { de treinamentos. }\end{array}$ & $\begin{array}{l}\text { Providenciar os registros de } \\
\text { todos os treinamentos. }\end{array}$ & $\begin{array}{l}\text { Ação Concluída. Foi elaborada uma pasta } \\
\text { para guardar os registros de todos os } \\
\text { treinamentos. }\end{array}$ \\
\hline $\begin{array}{l}\text { Alguns profissionais } \\
\text { sem identificação }\end{array}$ & $\begin{array}{l}\text { Providenciar crachás para } \\
\text { todos os profissionais. }\end{array}$ & $\begin{array}{l}\text { Ação Concluída. Todos os profissionais já } \\
\text { se encontram identificados através de } \\
\text { crachás padronizados pela instituição. }\end{array}$ \\
\hline $\begin{array}{l}\text { A agência não possui } \\
\text { gerador e nem plano } \\
\text { de contingência. }\end{array}$ & $\begin{array}{l}\text { Providenciar a confecção do } \\
\text { plano de contingência e } \\
\text { análise da estrutura para } \\
\text { implantar o gerador. }\end{array}$ & $\begin{array}{l}\text { Ação Concluída. Foi elaborado um plano } \\
\text { de contingência para falta de energia e, } \\
\text { recentemente, a instalação elétrica da } \\
\text { agência foi ligada ao gerador do hospital. }\end{array}$ \\
\hline
\end{tabular}

Fonte: resultados da pesquisa (2017).

A gestão da qualidade requer a participação de todos os membros da equipe, focados na busca de melhoria contínua. A participação dos colaboradores nessas ações contribui para seu engajamento nos processos de trabalho e para o cumprimento dos quesitos da qualidade no serviço. Além da aplicação do roteiro para a auditoria, é papel da gestão da qualidade estabelecer o cronograma anual para a realização das mesmas, bem como definir e capacitar os auditores.

\subsubsection{Desenvolvimento de educação continuada}

A Portaria de Consolidação MS $n^{\circ} 05$, de acordo com seu anexo IV, no $\S 1^{\circ}$ do art. 241, estabelece que o serviço de hemoterapia deve possuir programa de treinamento e capacitação de pessoal (BRASIL, 2017). A Resolução RDC ANVISA 
$n^{\circ} 34 / 2014$, em seu Artigo $7^{\circ}$, $\S 1^{\circ}$, também preconiza que "os serviços de hemoterapia devam garantir programas de capacitação e constante atualização técnica de todo o pessoal envolvido nos procedimentos, mantendo os respectivos registros, bem como, cumprir as determinações legais referentes à saúde dos trabalhadores e instruções de biossegurança" (BRASIL, 2014).

Com base nas exigências das legislações vigentes e na importância do desenvolvimento da educação continuada dentro das organizações, foram realizadas, durante o ano de 2016 e 2017, capacitações para os colaboradores da AT-HUJM, em que foram abordados assuntos referentes às áreas técnica e administrativa, com treinamento nos procedimentos operacionais e protocolos clínicos aprovados.

Para organizar estas capacitações, a Gestão da Qualidade da AT-HUJM, elaborou um Plano Anual de Capacitações, que visa programar e organizar as atualizações técnicas necessárias dos profissionais envolvidos no setor.

\subsubsection{Tratamento de reclamações e sugestões dos usuários - Ouvidoria}

A Ouvidoria representa, efetivamente, a voz do usuário na busca pela melhoria da qualidade do atendimento. A Ouvidoria é um serviço aberto a todo cidadão que queira apresentar suas reivindicações, denúncias, sugestões e elogios, referentes aos diversos serviços disponíveis à população. O objetivo da ouvidoria é atender a esta sociedade participativa.

A Portaria de Consolidação MS n 05, preconiza, no seu art. 239, que "o serviço de hemoterapia disporá de políticas e ações que assegurem a qualidade dos produtos e serviços, garantindo que os procedimentos e processos ocorram sob condições controladas" (BRASIL, 2017), com ações para o tratamento das reclamações e sugestões dos usuários.

No HUJM, existe um setor específico de ouvidoria, vinculado a Superintendência, que abrange todos os setores do hospital, inclusive a AT. Trata-se de um órgão de comunicação com o cidadão em geral, dirigentes, corpos docente e discente, pesquisadores, prestadores de serviços, fornecedores, servidores e empregados. Ele visa ao aperfeiçoamento do modelo administrativo e das ações 
institucionais e à constante melhoria dos processos internos, em prol dos usuários do Sistema Único de Saúde.

O acesso do cidadão à Ouvidoria ocorre de todas as maneiras possíveis, através de: e-mail, carta, formulários eletrônicos e impressos, caixas de coleta, telefone e atendimento presencial personalizado. Foram instaladas, em locais de grande circulação do hospital, caixas de coletas, devidamente identificadas, para registros de manifestações por meio de formulário impresso, disponibilizado pela Ouvidoria. A Ouvidoria elabora, periodicamente, relatório de atendimento com a descrição de reclamações, sugestões, elogios, solicitações e denúncias, discriminadas por assunto e área demandada.

\subsubsection{Realização de pesquisas de satisfação e de opinião}

A realização de pesquisas de satisfação é uma importante ação dentro da GQ, já que essas pesquisas são excelentes instrumentos para avaliação do nível de satisfação dos clientes com relação aos serviços e produtos da instituição. As pesquisas de opinião também apresentam grande relevância, uma vez que os resultados obtidos com elas podem embasar tomadas de decisões, conhecendo-se as opiniões dos entrevistados. De modo geral, estas pesquisas, tanto as de satisfação, como as de opinião, têm como foco melhorar o desempenho das organizações.

Através da Ouvidoria, todos os anos, o HUJM realiza Ciclos de Pesquisa de Satisfação dos Usuários, evolvendo os setores do hospital, será sugerido que para próxima pesquisa, a AT seja avaliada, referente à satisfação dos setores do hospital atendidos pela AT e satisfação dos receptores de transfusão.

\subsubsection{Elaboração do Plano de Contingência para a cadeia do frio}

A cadeia do frio abrange todos os equipamentos utilizados para armazenamento e conservação dos hemocomponentes e insumos envolvidos na 
sua conservação e preparo, bem como nos testes laboratoriais relacionados com as transfusões. Considerando os riscos que podem advir de não conformidades em seus processos, os serviços de hemoterapia precisam definir as medidas a serem tomadas quando um problema ocorrer, já que são locais onde se coleta, produz e armazena hemocomponentes.

A Portaria de Consolidação MS n 05, de acordo com o anexo IV determina, no $\S 6^{\circ}$ do artigo 249 , que "será disponibilizado um plano de contingência formal para as situações de não conformidades na temperatura de armazenamento, que descreva as medidas a serem tomadas em tais situações, para garantir a adequada preservação dos componentes armazenados" (BRASIL, 2017).

A Resolução RDC AVISA $n^{\circ} 34$, no seu art. 20, também estabelece a necessidade da definição de procedimento escrito para intercorrências com os equipamentos da cadeia do frio, preconizando que "o serviço de hemoterapia deve ter plano de contingência escrito e disponível para casos de interrupção de fornecimento de energia e eventuais problemas na cadeia de frio" (BRASIL, 2014).

Diante disto e também como atividade da $\mathrm{GQ}$, foi elaborado um Plano de Contingência para a cadeia do frio da AT-HUJM, com o objetivo de padronizar o procedimento de armazenamento de hemocomponentes, amostras e reagentes em casos de cortes de energia elétrica ou quebra de equipamentos da cadeia do frio, visando à conservação dos hemocomponentes e insumos existentes na instalação.

Este plano definiu o local para o qual devem ser transferidos os produtos armazenados em cada equipamento quando ocorrer falta de energia elétrica ou algum equipamento estiver danificado. Também consta deste plano, a forma de contato com os profissionais que devem ser comunicados assim que esta intercorrência acontecer.

Em julho de 2017, a instalação elétrica da AT-HUJM foi ligada ao gerador do hospital, assegurando o fornecimento de energia.

\subsubsection{Implantação dos indicadores}

Qualidade deve ser medida através dos produtos resultantes dos processos (BITTAR, 2004). Para o monitoramento da qualidade, o banco de sangue ou serviço 
de transfusão deve ter um processo de coleta e avaliação de dados de indicadores de qualidade, em intervalos programados. Pode-se definir indicador como uma informação de natureza qualitativa ou quantitativa, associada a um evento, processo ou resultado, sendo possível avaliar as mudanças durante o tempo e verificar ou definir objetivos ou utilizá-lo para a tomada de decisões ou escolhas (PLEBANI, 2009).

Os indicadores têm como objetivo o acompanhamento dos padrões e metas estabelecidos, auxiliando no sistema de gestão da qualidade e nas ações de planejamento e de melhoria continua. Um bom indicador deve fornecer parâmetros para avaliação dos processos, além de demonstrar a confiabilidade dos resultados obtidos (MALIK; SCHIESARI, 1998).

Como característica, um indicador deve ser baseado em padrões científicos e descrito de acordo com sua capacidade de prever resultados, podendo detectar não conformidades dos processos, sendo desejável que permita comparações úteis e ser baseado em evidências (MAINZ, 2003).

A definição do número e dos tipos de indicadores costuma ter como base a complexidade e o tamanho da organização, assim como a missão e os objetivos do serviço (SCIACOVELLI et al., 2007).

Segundo Vieira et al., (2011) a falta de um padrão internacional, ou mesmo nacional, dificulta a definição de metas ou objetivos, assim como a prática de benchmarking, visto que um mesmo indicador pode diferir no modo de reportar os dados, na coleta dos mesmos e na metodologia utilizada para expressar o indicador (percentual ou números absolutos).

Após verificação dos resultados apresentados pelo grupo de indicadores e identificação de um potencial e possível não conformidade no processo, é necessária a elaboração de um plano de ação, adotando alguma das ferramentas que o sistema de gestão da qualidade oferece. Assim, a análise crítica dos indicadores, possibilita a proposição de soluções eficazes e a antecipação da tratativa aos problemas em potencial, que podem gerar variações desnecessárias ao processo, produto ou serviço (DEMING,1990).

De maneira geral, a ausência de indicadores de qualidade foi uma não conformidade importante observada na AT-HUJM. Através do benchmarking realizado com Hemocentro-RP, foi possível conhecer as principais áreas e objetivos em que se aplica análise dos indicadores no serviço de hemoterapia. 
Isto facilitou o início do processo de implantação dos indicadores na AT, visando obter uma análise mais concreta da situação do serviço para, então, propor ações de melhoria, com foco no acompanhamento dos resultados dos indicadores, bem como na identificação e prevenção de não conformidades.

O Quadro 13 mostra os indicadores implantados na AT-HUJM e o Quadro 14 apresenta as fórmulas utilizadas para calcular cada um deles.

Quadro 13 - Indicadores Implantados na AT- HUJM

\begin{tabular}{|c|c|}
\hline Indicador & Objetivo \\
\hline $\begin{array}{c}\text { Frequência de Pesquisa } \\
\text { Anticorpo Irregular (PAI) } \\
\text { Positivo }\end{array}$ & $\begin{array}{l}\text { Avaliar o número de pacientes com PAI Positivo e o envio de } \\
\text { amostras para investigação Imuno-hematológica }\end{array}$ \\
\hline $\begin{array}{c}\text { Transfusões/ } \\
\text { Clínica }\end{array}$ & Monitorar as transfusões no hospital \\
\hline Reações Transfusionais & Monitorar as reações transfusionais \\
\hline $\begin{array}{l}\text { Reações Transfusionais/ } \\
\text { Tipo de Hemocomponente }\end{array}$ & $\begin{array}{l}\text { Relacionar as reações transfusionais com o tipo de } \\
\text { hemocomponente }\end{array}$ \\
\hline $\begin{array}{l}\text { Perfil Epidemiológico das } \\
\text { Reações Transfusionais }\end{array}$ & Identificar as principais reações transfusionais \\
\hline $\begin{array}{c}\text { Compatibilização } \\
\text { Desnecessária }\end{array}$ & $\begin{array}{c}\text { Avaliar o desperdício (tempo e insumos) com pacientes não } \\
\text { transfundidos }\end{array}$ \\
\hline $\begin{array}{l}\text { Reservas Cirúrgicas não } \\
\text { utilizadas }\end{array}$ & $\begin{array}{c}\text { Avaliar as reservas de solicitação de hemocomponentes } \\
\text { desnecessárias }\end{array}$ \\
\hline $\begin{array}{l}\text { Bolsas Descartadas por } \\
\text { Vencimento }\end{array}$ & Monitorar o descarte de bolsas \\
\hline $\begin{array}{l}\text { Bolsas Descartadas por } \\
\text { Outros Motivos }\end{array}$ & Monitorar o descarte de bolsas \\
\hline
\end{tabular}

Fonte: resultados da pesquisa (2017).

Quadro 14 - Fórmulas de cálculos dos indicadores da AT-HUJM

\begin{tabular}{|c|c|}
\hline Indicador & Fórmula \\
\hline $\begin{array}{c}\text { Frequência de Pesquisa } \\
\text { Anticorpo Irregular (PAI) } \\
\text { Positivo }\end{array}$ & $\operatorname{FPP}(\%)=\frac{n^{\circ} \text { PAl positivo }}{n^{\circ} \text { PAl realizados }} \times 100$ \\
\hline $\begin{array}{l}\text { Transfusões/ } \\
\text { Clínica }\end{array}$ & $\mathrm{TC}(\%)=\frac{\mathrm{n}^{\circ} \text { transfusões por clínica }}{\mathrm{n}^{\circ} \text { total de transfusões }} \times 100$ \\
\hline Reações Transfusionais & $\mathrm{RT}(\%)=\frac{\mathrm{n}^{\circ} \text { total de reações transfusionais }}{\mathrm{n}^{\circ} \text { total de transfusões }} \times 100$ \\
\hline $\begin{array}{l}\text { Reações Transfusionais/ } \\
\text { Tipo de Hemocomponente }\end{array}$ & $\begin{array}{c}\text { RTH }(\%)=n^{\circ} \text { total de RT por hemocomponte } \\
n^{\circ} \text { total de hemocomponente transfundido }\end{array}$ \\
\hline
\end{tabular}


(continuação)

\begin{tabular}{|cc|}
\hline $\begin{array}{c}\text { Indicador } \\
\text { Perfil Epidemiológico das } \\
\text { Reações Transfusionais }\end{array}$ & PERT $(\%)=\frac{\mathrm{n}^{\circ} \text { de reações transfusionais por tipo }}{\mathrm{n}^{\circ} \text { total de reações transfusionais }} \times 100$ \\
$\begin{array}{c}\text { Compatibilização } \\
\text { Desnecessária }\end{array}$ & $\mathrm{PC}(\%)=\frac{\mathrm{n} \text { - bolsas compatibilizadas não transfundidas }}{\mathrm{n} \text { - bolsas compatibilizadas transfundidas }} \times 100$ \\
$\begin{array}{c}\text { Reservas Cirúrgicas não } \\
\text { utilizadas }\end{array}$ & $\mathrm{RNT}(\%)=\frac{\mathrm{n}^{\circ} \text { bolsas reservadas e não transfundidas }}{\mathrm{n}^{\circ} \text { bolsas reservadas }} 100$ \\
$\begin{array}{c}\text { Bolsas Descartadas por } \\
\text { Vencimento }\end{array}$ & $\mathrm{BDV}(\%)=\frac{\mathrm{n}^{\circ} \text { hemocomponente descartado por vencimento }}{\mathrm{n}^{\circ} \text { hemocomponente recebido }} \times 100$ \\
$\begin{array}{c}\text { Bolsas Descartadas por } \\
\text { Outros Motivos }\end{array}$ & $\mathrm{BDO}(\%)=\frac{\mathrm{n}^{\circ} \text { hemocomponente descartado outros motivos }}{\mathrm{n} \text { - hemocomponente recebido }} \times 100$ \\
\hline
\end{tabular}

Fonte: resultados da pesquisa (2017).

Os indicadores da AT-HUJM foram selecionados para avaliar: intercorrências imuno-hematológicas dos receptores, perfil das transfusões realizadas, perfil das reações transfusionais, desperdício com bolsas não transfundidas e descarte de hemocomponentes.

A análise retrospectiva do ano de 2016 e do primeiro semestre de 2017 permitiu que seus resultados gerassem informações sobre os processos da AT e servissem de base para as metas que serão estabelecidas para os próximos semestres. A apresentação dos indicadores escolhidos está indexada no texto abaixo.

\section{Indicador Frequência de Pesquisa Anticorpo Irregular (PAI) Positivo}

Este indicador pode servir para se:

a. Analisar o \% de PAI positivo na AT cujo resultado foi confirmado positivo no Hemocentro e, com isto, avaliar o desempenho dos profissionais da AT e a necessidade de seu treinamento;

b. Pesquisar quais anticorpos se formaram em decorrência de transfusões preparadas pela AT-HJUM e avaliar a prática transfusional da AT e a implantação de protocolo de transfusão de bolsas fenotipadas para algumas situações/pacientes.

A Portaria de Consolidação MS n ${ }^{\circ} 05$, anexo IV, determina, nos $\S 3^{\circ}$ e $4^{\circ}$ do artigo 178, que: 
...quando a pesquisa de anticorpos antieritrocitários irregulares mostrar resultados positivos, recomenda-se a identificação da especificidade do(s) anticorpo(s) detectado(s) para seleção segura de concentrados de hemácias fenotipados a serem transfundidos. Se o serviço não realizar a identificação, recomenda-se que amostras do paciente sejam encaminhadas a um serviço de imuno-hematologia eritrocitário de referência, para completar a investigação laboratorial. (BRASIL, 2017, p. 272).

A AT-HUJM encaminha as amostras de paciente com PAI positivo para o laboratório de imuno-hematologia de referência, do hemocentro coordenador, MTHemocento.

A Figura 8 apresenta o gráfico que mostra o número de PAI realizado na ATHUJM, nos dois semestres de 2016 e no primeiro semestre de 2017. Os resultados mostram que o número de exames realizados no primeiro semestre de 2017, aumentou em relação ao primeiro semestre de 2016, em virtude do aumento da oferta de leitos aos usuários do SUS do HUJM. Já o índice de frequência de PAI positivos (Figura 9), no primeiro semestre de 2017, reduziu em relação a 2016, devido à internação de pacientes novos, que não eram politransfundidos.

Figura 8 - Gráfico da quantidade de PAI realizados

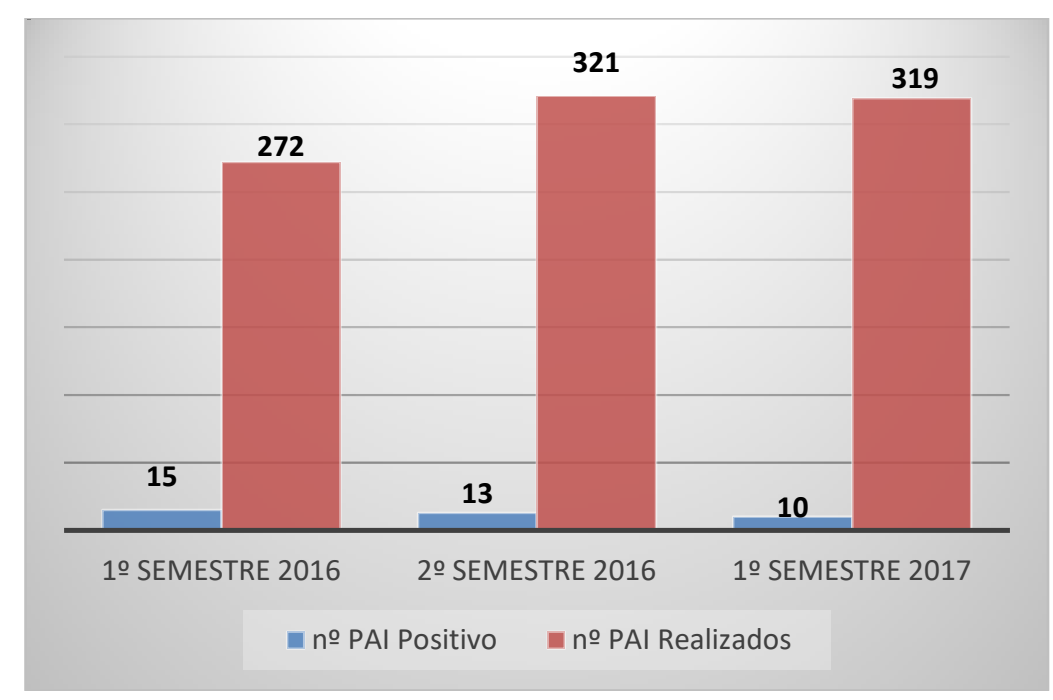

Fonte: resultados da pesquisa (2017). 
Figura 9 - Gráfico do índice de frequência de PAI positivo

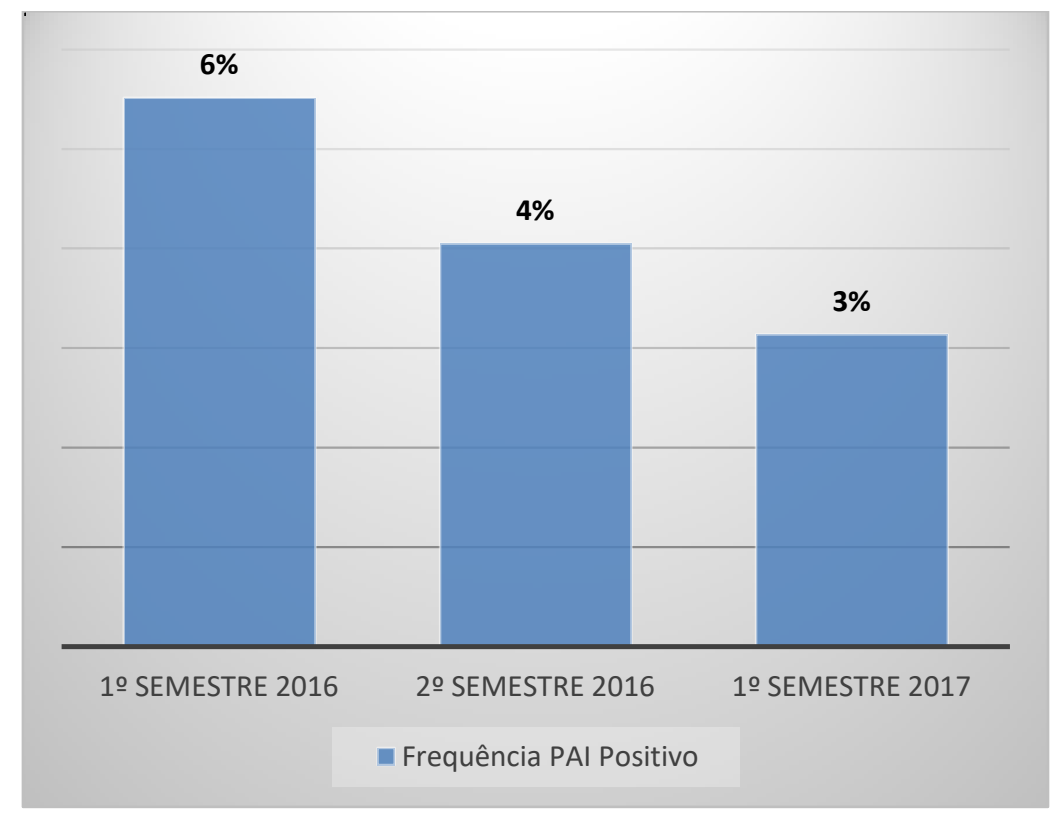

Fonte: resultados da pesquisa (2017).

\section{Indicador Transfusões por Clínica}

O HUJM possui 124 leitos entre enfermarias e UTI, adulto e neonatal. Este indicador tem como objetivo avaliar as transfusões realizadas no hospital e identificar ações de conscientização da equipe médica para utilização racional de hemocomponentes.

As figuras 10 e 11 apresentam gráficos com os dados obtidos. O número semestral de transfusões realizadas em 2016 foi menor que no primeiro semestre de 2017, sendo que em todos os semestres avaliados, as clínicas em que mais ocorreu transfusão foram UTI adulto e clínica médica. 
Figura 10 - Gráfico da quantidade de transfusões

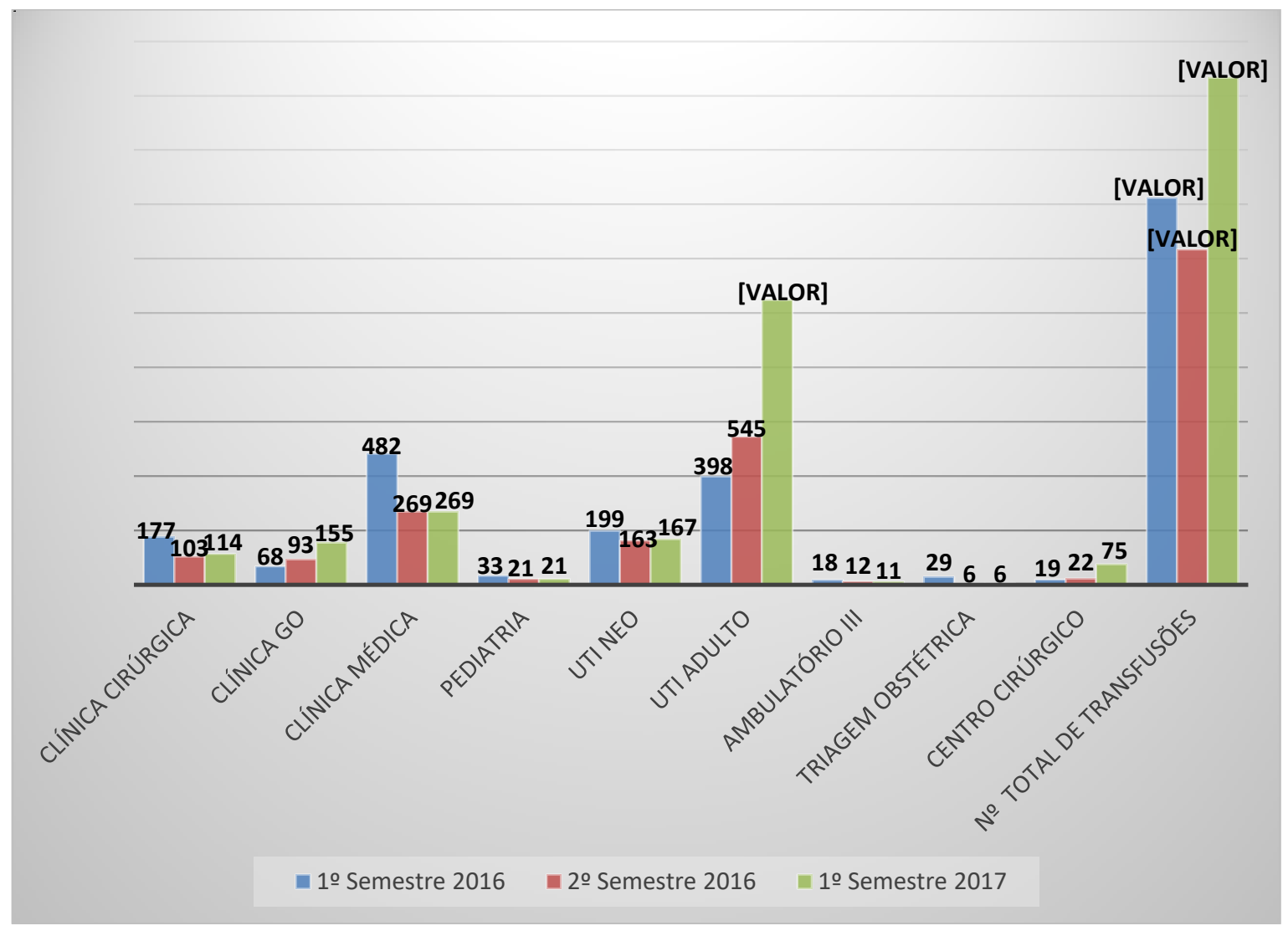

Fonte: resultados da pesquisa (2017).

Figura 11 - Gráfico do índice de transfusões por clínica

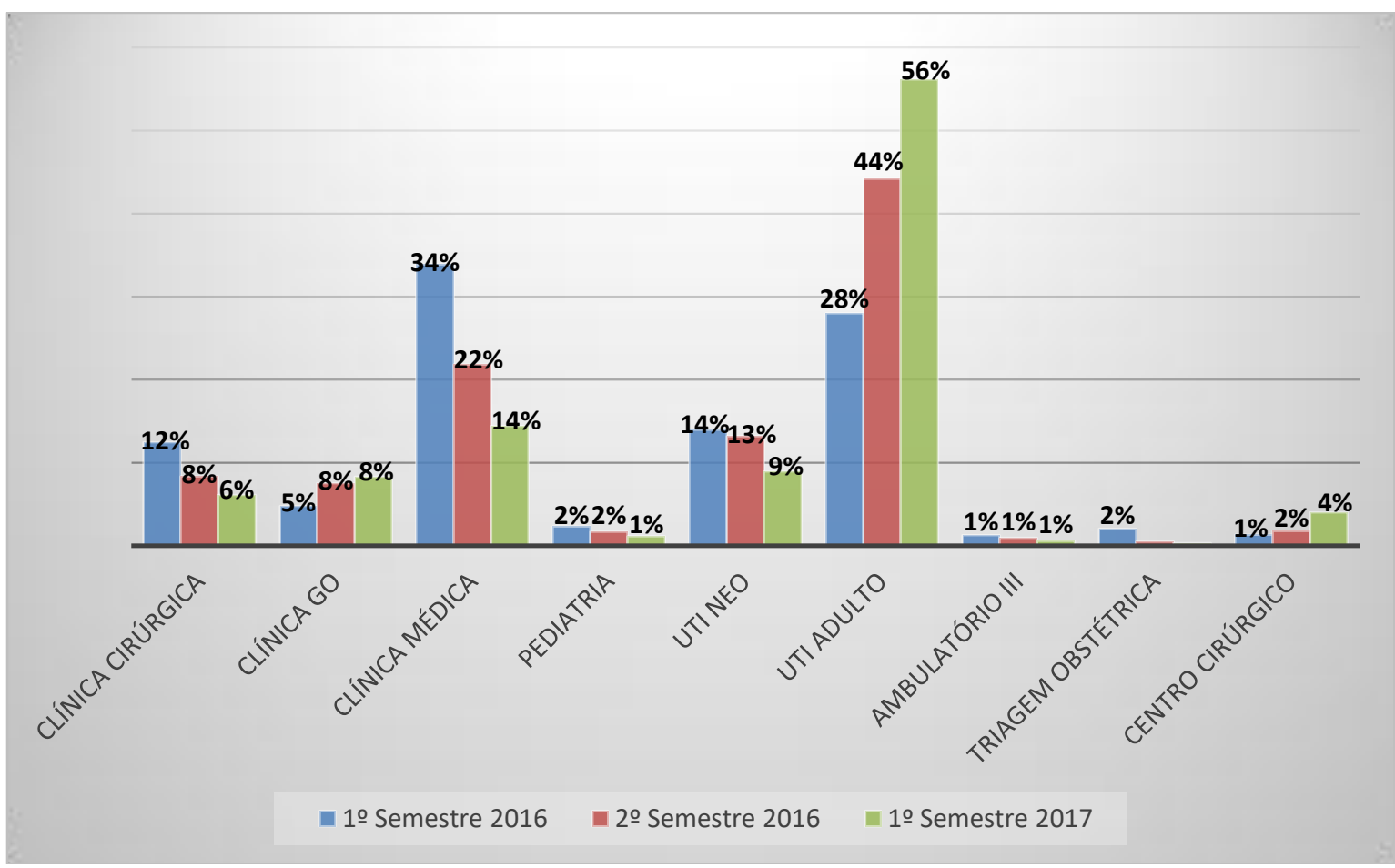

Fonte: resultados da pesquisa (2017). 


\section{Indicador Reações Transfusionais}

Conforme a Portaria de Consolidação MS n 05, anexo IV, artigo 205, "a instituição de assistência à saúde que realiza transfusões terá um sistema para detecção, notificação e avaliação das reações transfusionais" (BRASIL, 2017). De acordo com os números encontrados, percebe-se que ainda existe um grande percentual de subnotificações de reações transfusionais, considerando o parâmetro de ocorrência do sistema francês na década de 1990, de 3 RT (reações transfusionais) para 1.000 transfusões sanguíneas. Pois, pelo número de transfusões realizadas no primeiro e segundo semestre de 2016, foi notificada uma média de apenas 04 reações transfusionais, gerando um índice 2,67 RT/1.000 transfusões. Já no primeiro semestre de 2017, em 1.866 transfusões foram registradas 03 reações transfusionais, diminuindo o índice para 1,61 RT/1.000 transfusões.

O objetivo deste indicador é aumentar do número de notificações de reações transfusionais e, para tanto, será necessária a participação do comitê transfusional tanto na elaboração de um plano de educação continuada das equipes assistenciais como no desenvolvimento de campanha para sua conscientização sobre a importância da identificação, registro e manejo dos incidentes transfusionais.

Os gráficos das figuras 17 e 18 mostram os dados obtidos.

Figura 12 - Gráfico da quantidade de transfusões x reações transfusionais

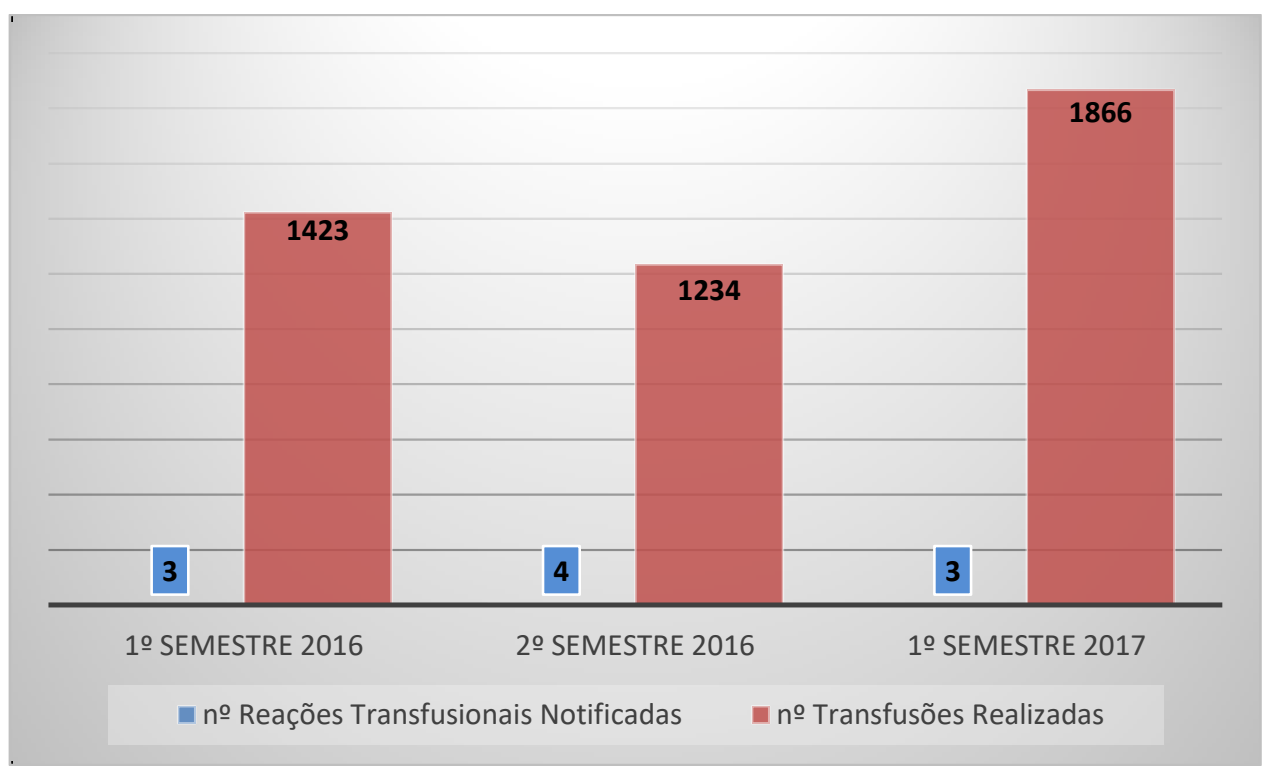

Fonte: resultados da pesquisa (2017). 
Figura 13 - Gráfico do índice de reações transfusionais/1000 transfusões

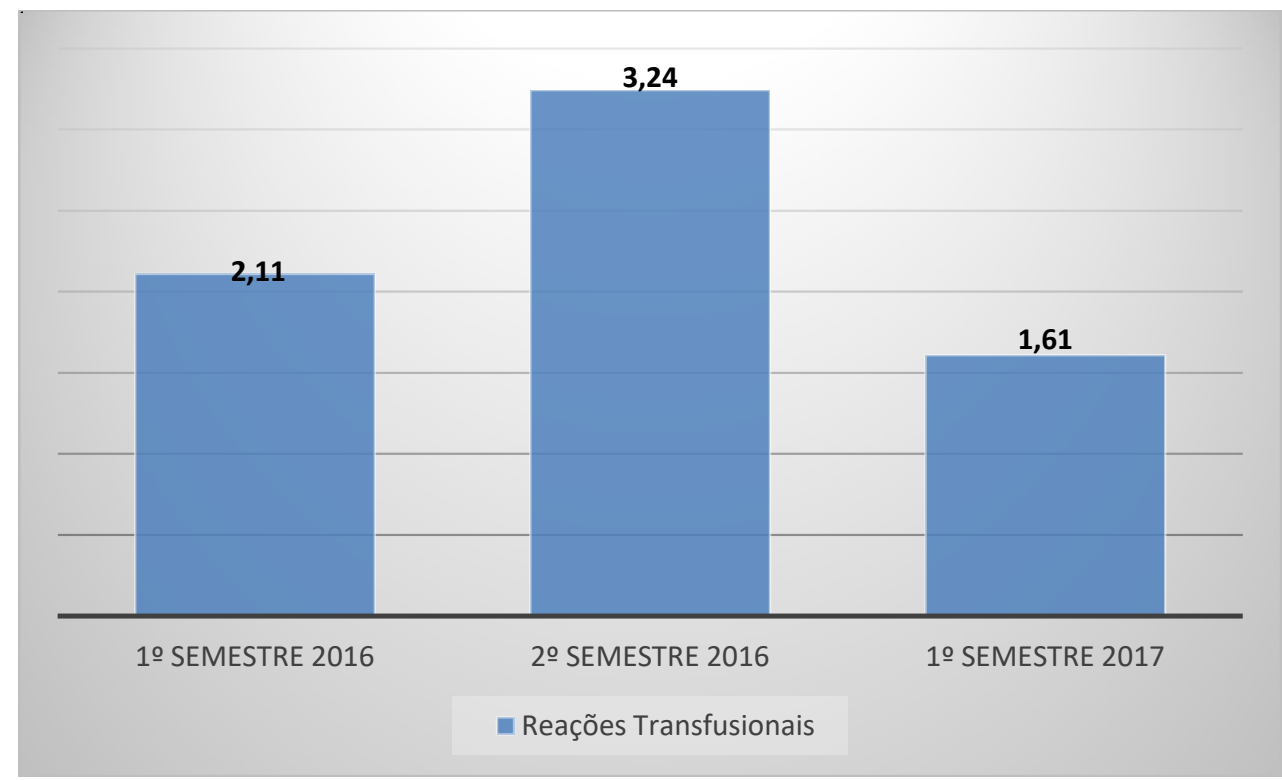

Fonte: resultados da pesquisa (2017).

\section{Indicador reações transfusionais por tipo de hemocomponente}

Este indicador visa monitorar quais hemocomponentes causaram reações transfusionais. Em 2016, concentrado de hemácias e plasma fresco congelado foram os hemocomponentes que causaram reações transfusionais. Já no primeiro semestre de 2017, foram concentrados de hemácia e concentrado de plaquetas. Os gráficos das figuras 14 e 15 mostram os dados obtidos.

Figura 14 - Gráfico da quantidade de reações transfusionais por tipo de hemocomponente

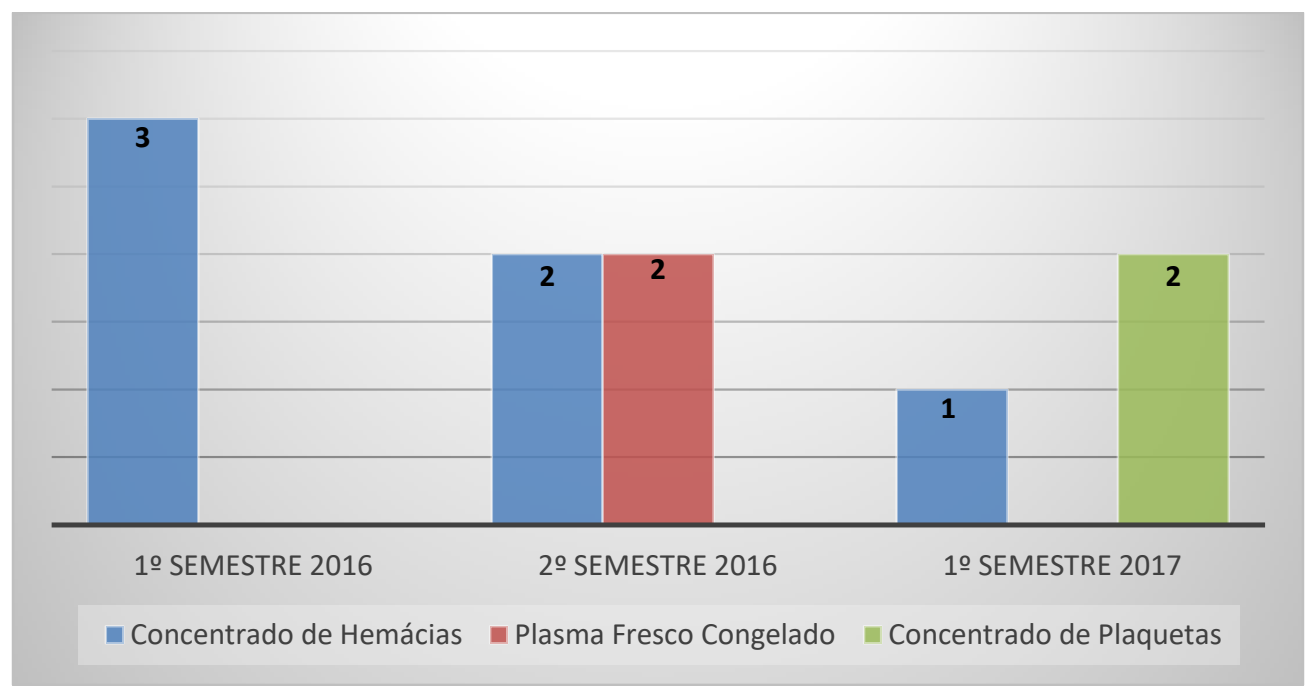

Fonte: resultados da pesquisa (2017). 
Figura 15 - Gráfico do índice reações transfusionais por tipo de hemocomponente

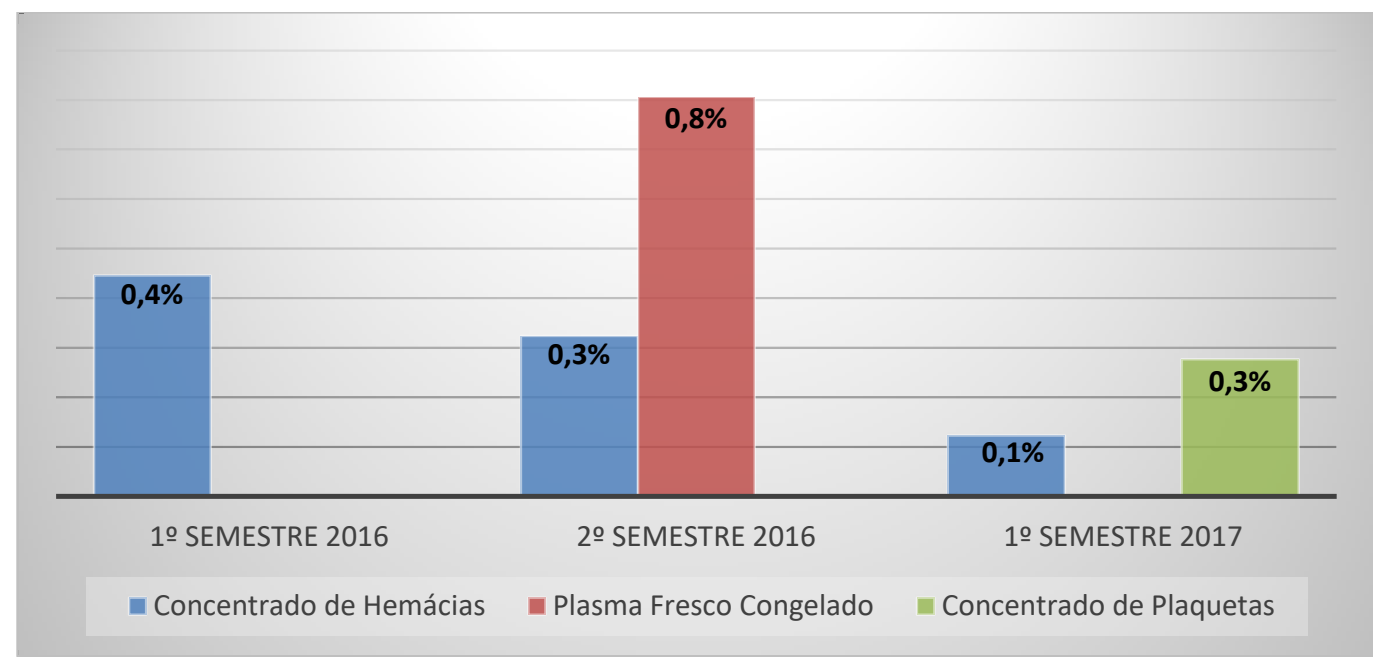

Fonte: resultados da pesquisa (2017).

\section{Indicador perfil epidemiológico das reações transfusionais}

Este indicador visa identificar os principais tipos de reações transfusionais. Em 2016, a reação mais notificada foi a alérgica (leve ou moderada), seguida da reação febril não hemolíticas, hemólise não imune e dor aguda relacionada à transfusão. No primeiro semestre de 2017, a mais notificada permaneceu a reação alérgica, seguida de suspeita de TRALI/ Edema pulmonar. As Figuras 16 e 17 mostram os resultados obtidos.

Figura 16 - Gráfico da quantidade de reações transfusionais por tipo

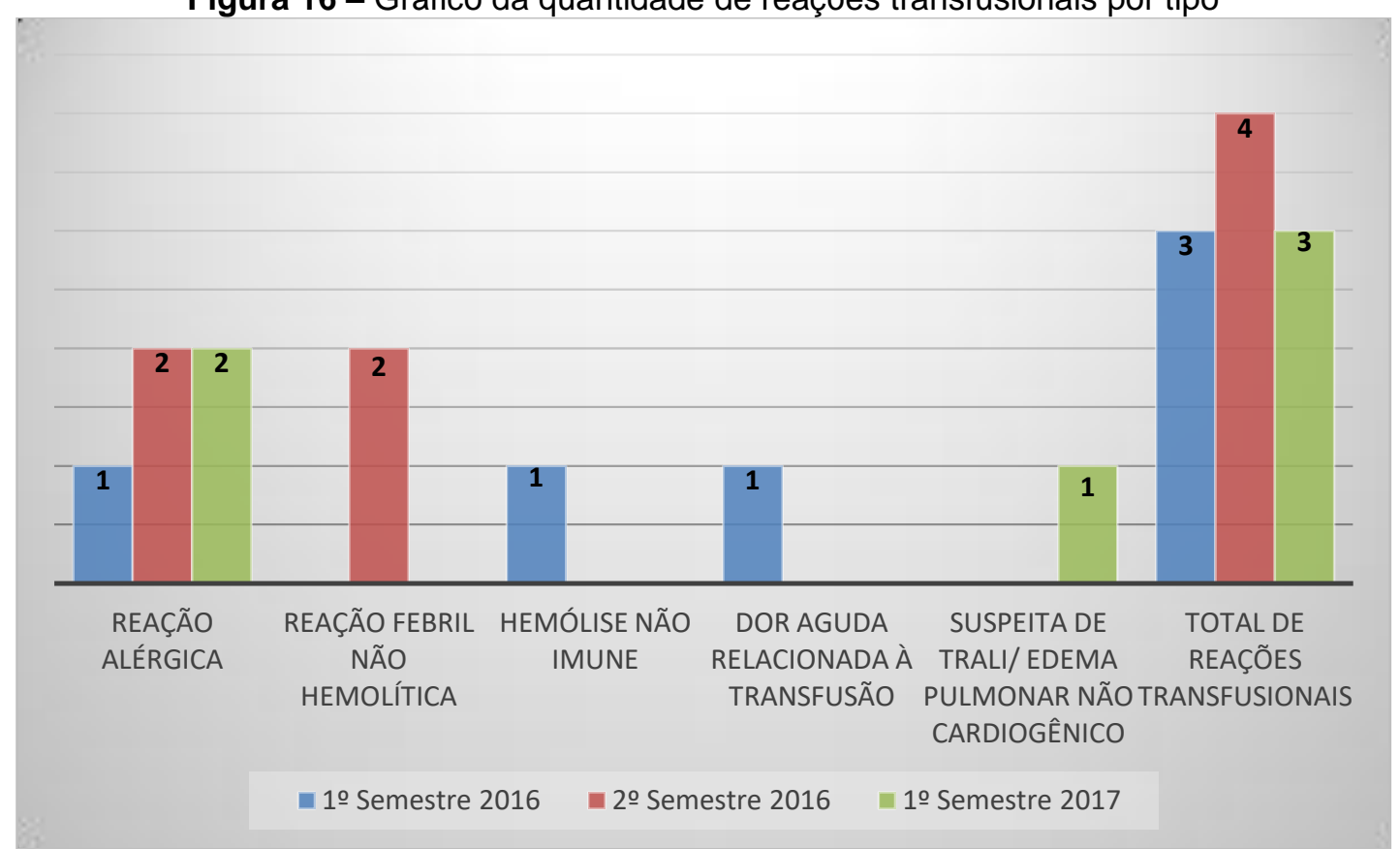

Fonte: resultados da pesquisa (2017). 
Figura 177 - Gráfico do índice perfil epidemiológico das reações transfusionais

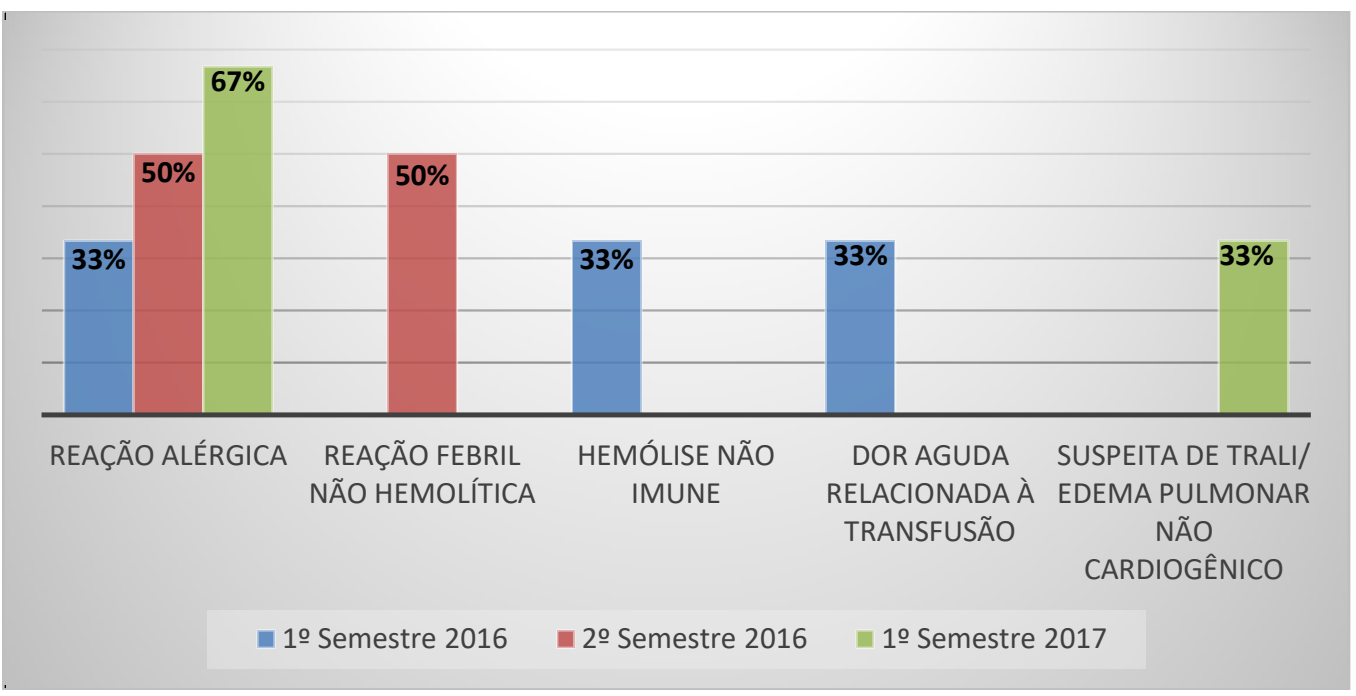

Fonte: resultados da pesquisa (2017).

\section{Indicador compatibilização desnecessária}

Este indicador permite uma avaliação do desperdício (tempo e insumos) com compatibilização de concentrados de hemácia que, por algum motivo (ex.: óbito, reavaliação do paciente após exames laboratoriais) não são transfundidos, visando propostas de ações para conscientização da equipe médica.

Conforme mostra as figuras 18 e 19, o número de bolsas compatibilizadas e não transfundidas vem aumentando a cada semestre, resultando em um índice de $20 \%$ de compatibilização desnecessária.

Figura 188 - Gráfico da quantidade de bolsas compatibilizadas

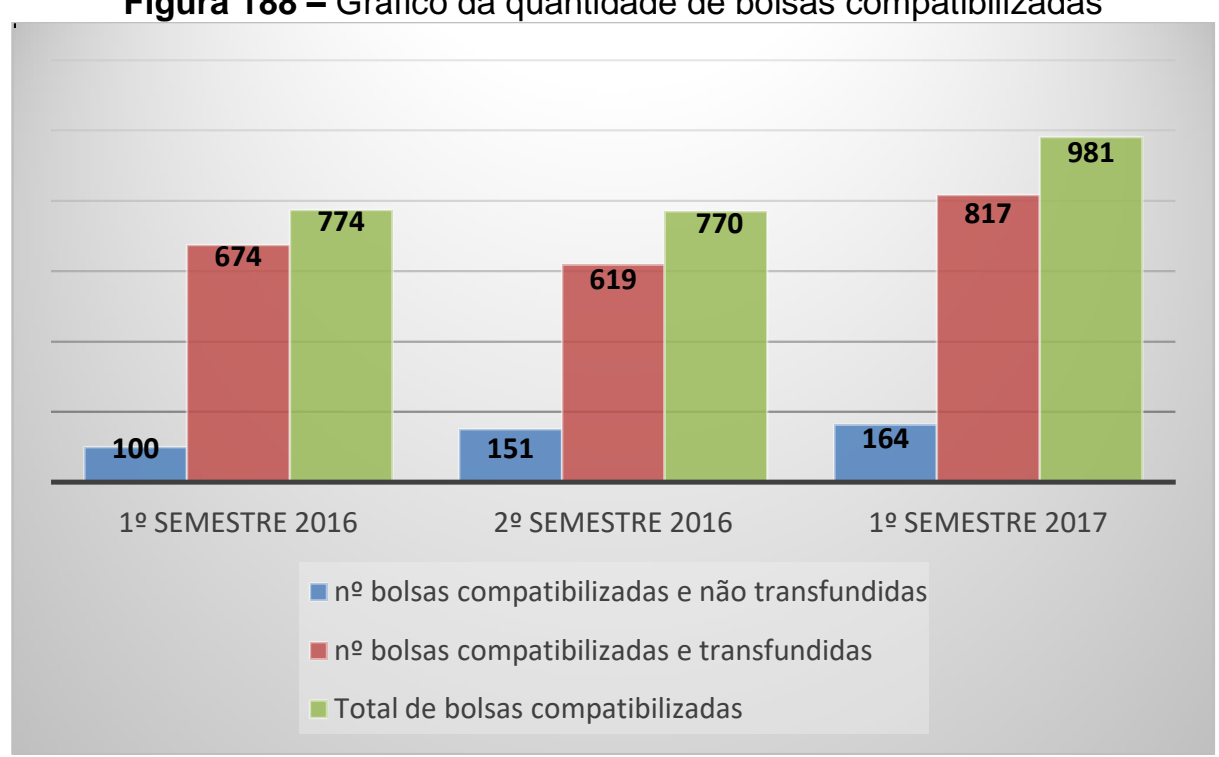

Fonte: resultados da pesquisa (2017). 
Figura 199 - Gráfico do índice de compatibilização desnecessária

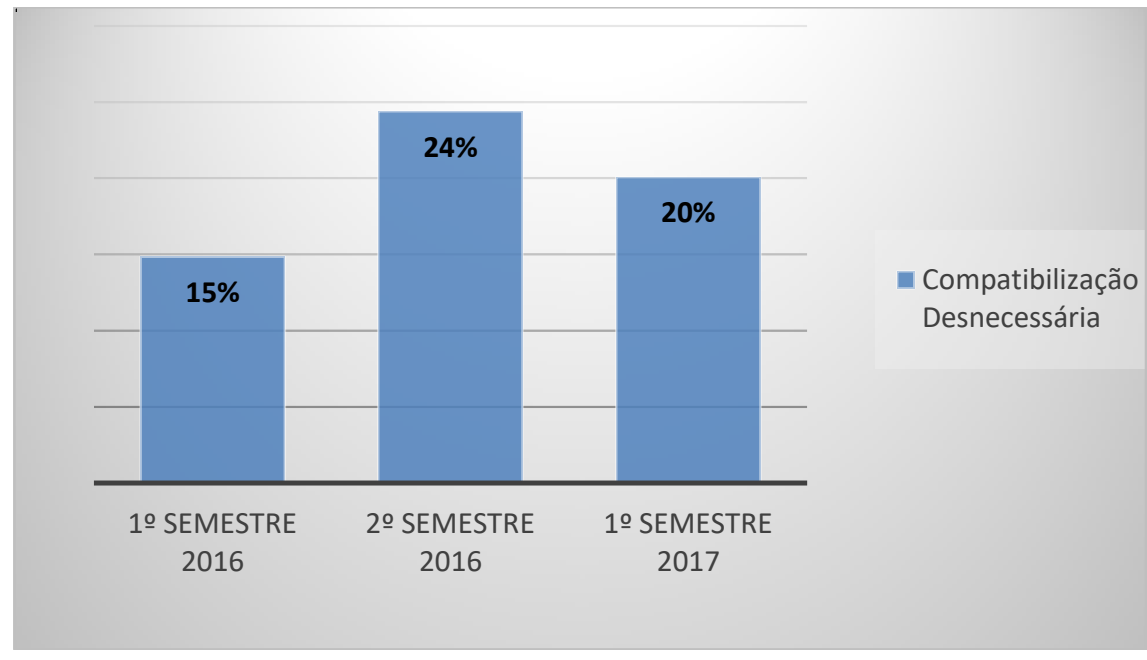

Fonte: resultados da pesquisa (2017).

\section{Indicador de reservas cirúrgicas não utilizadas}

Assim como o indicador anterior, este procura, avaliar o desperdício (tempo e insumos) com reservas para cirurgias desnecessárias, visando propostas de conscientização da equipe médica e implantação de um protocolo de reservas cirúrgicas no hospital.

Conforme mostra as figuras 20 e 21, o número de bolsas reservadas e não utilizadas nas cirurgias vem aumentando a cada semestre, resultando em um índice médio de $\sim 77 \%$ de reservas cirúrgicas não utilizadas.

Figura 20 - Gráfico da quantidade de bolsas reservadas

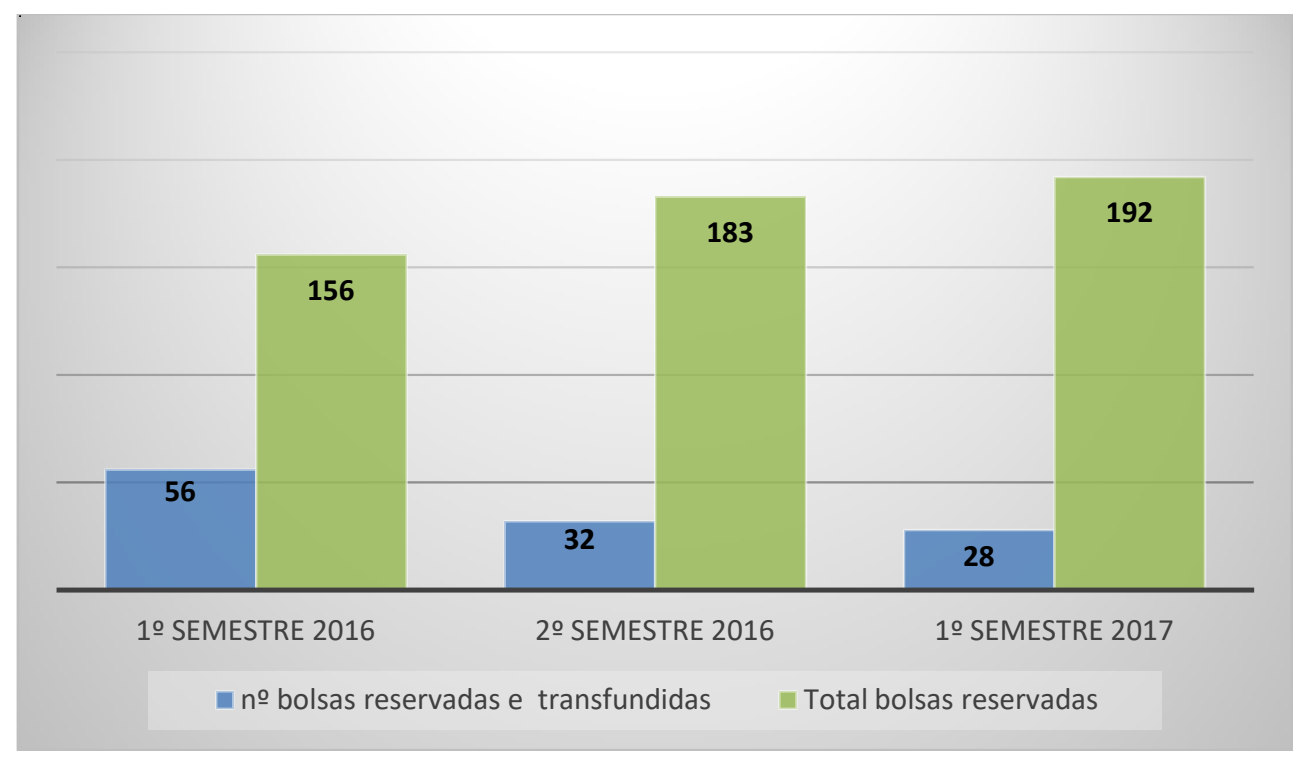

Fonte: resultados da pesquisa (2017). 
Figura 21 - Gráfico do Índice de reservas cirúrgicas não utilizadas

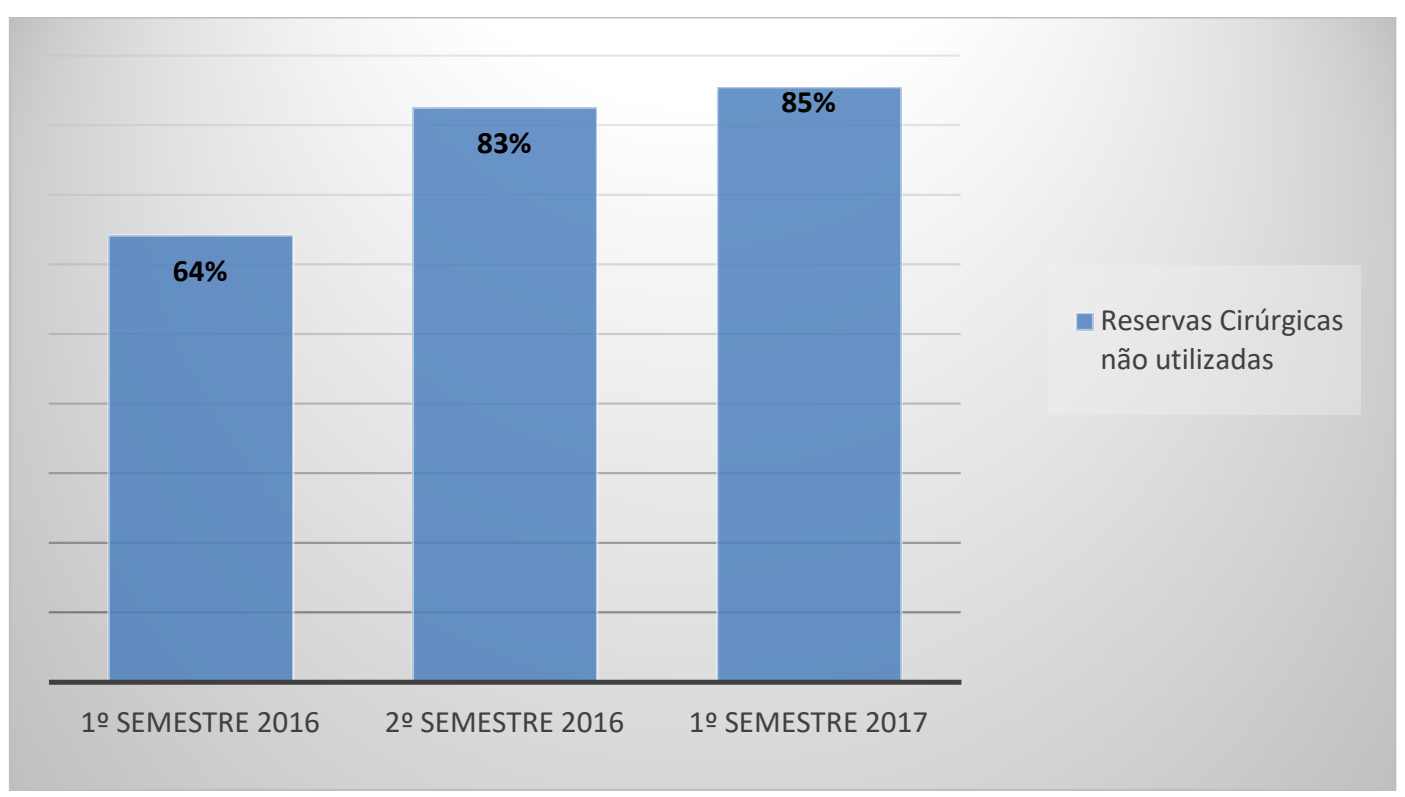

Fonte: resultados da pesquisa (2017).

\section{Indicador de bolsas descartadas por vencimento}

Este indicador monitora o descarte de bolsas de hemocomponentes por vencimento, visando orientar ações que minimizem perdas. $O$ hemocomponente mais descartado por vencimento nos semestres avaliados foi o concentrado de plaquetas. Em seguida, foi o concentrado de hemácias, porém, quando se analisa o hemocomponente mais recebido, essa sequência se inverte.

Relacionando o número de hemocomponente recebidos com 0 de descartados por vencimento, em 2016, o crioprecipitado foi o mais descartado, seguido pelo concentrado de plaquetas; plaqueta aférese; concentrado de hemácia e plasma fresco congelado.

No $1^{\circ}$ semestre de 2017, o concentrado de plaquetas por aférese foi o mais descartado, seguido pelo concentrado de plaquetas randômicas; concentrado de hemácia; crioprecipitado e plasma fresco congelado.

As figuras 22, 23 e 24 apresentam os resultados obtidos. 
Figura 22 - Gráfico da quantidade de hemocomponentes recebidos

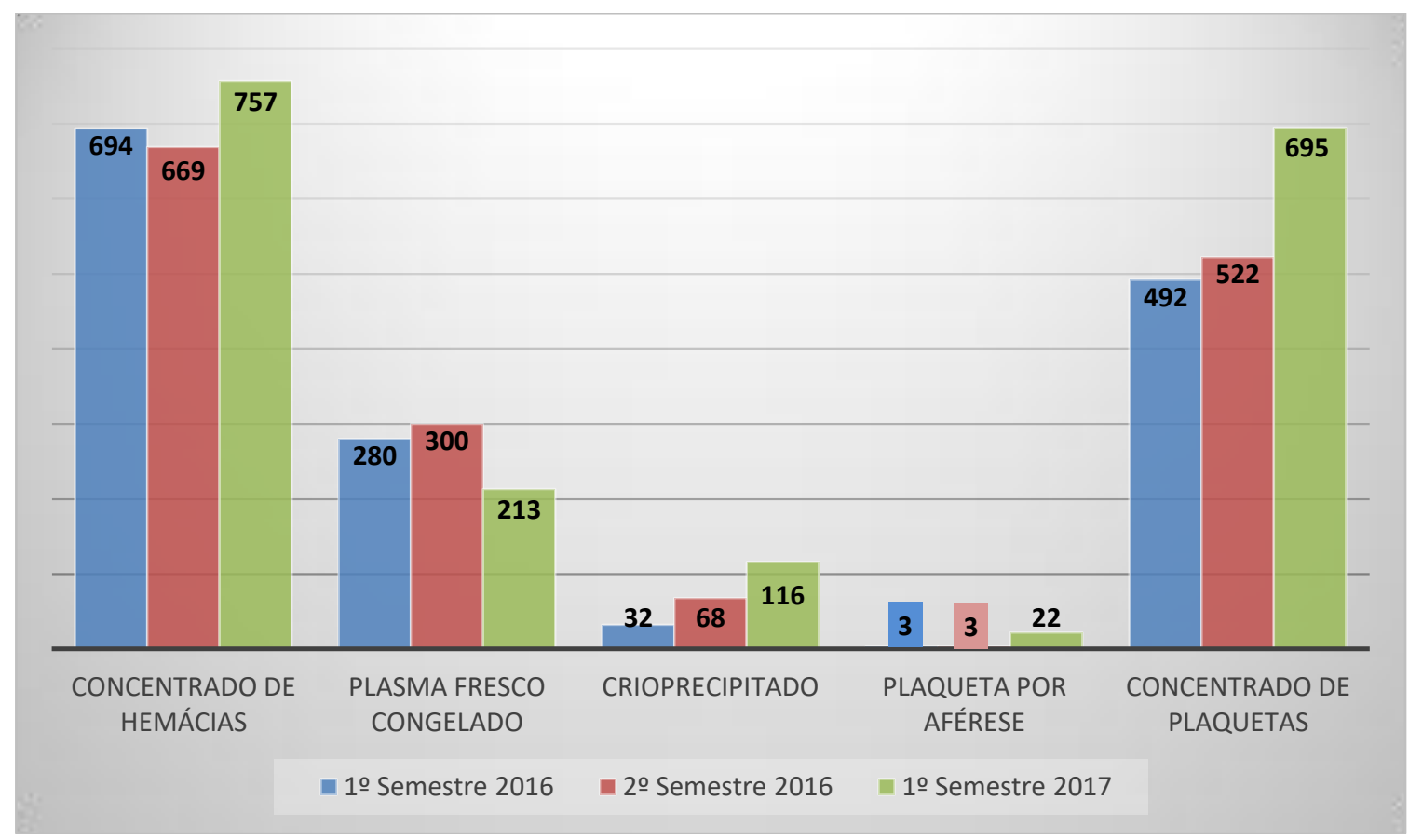

Fonte: resultados da pesquisa (2017).

Figura 23 - Gráfico da quantidade de hemocomponentes descartados por vencimento

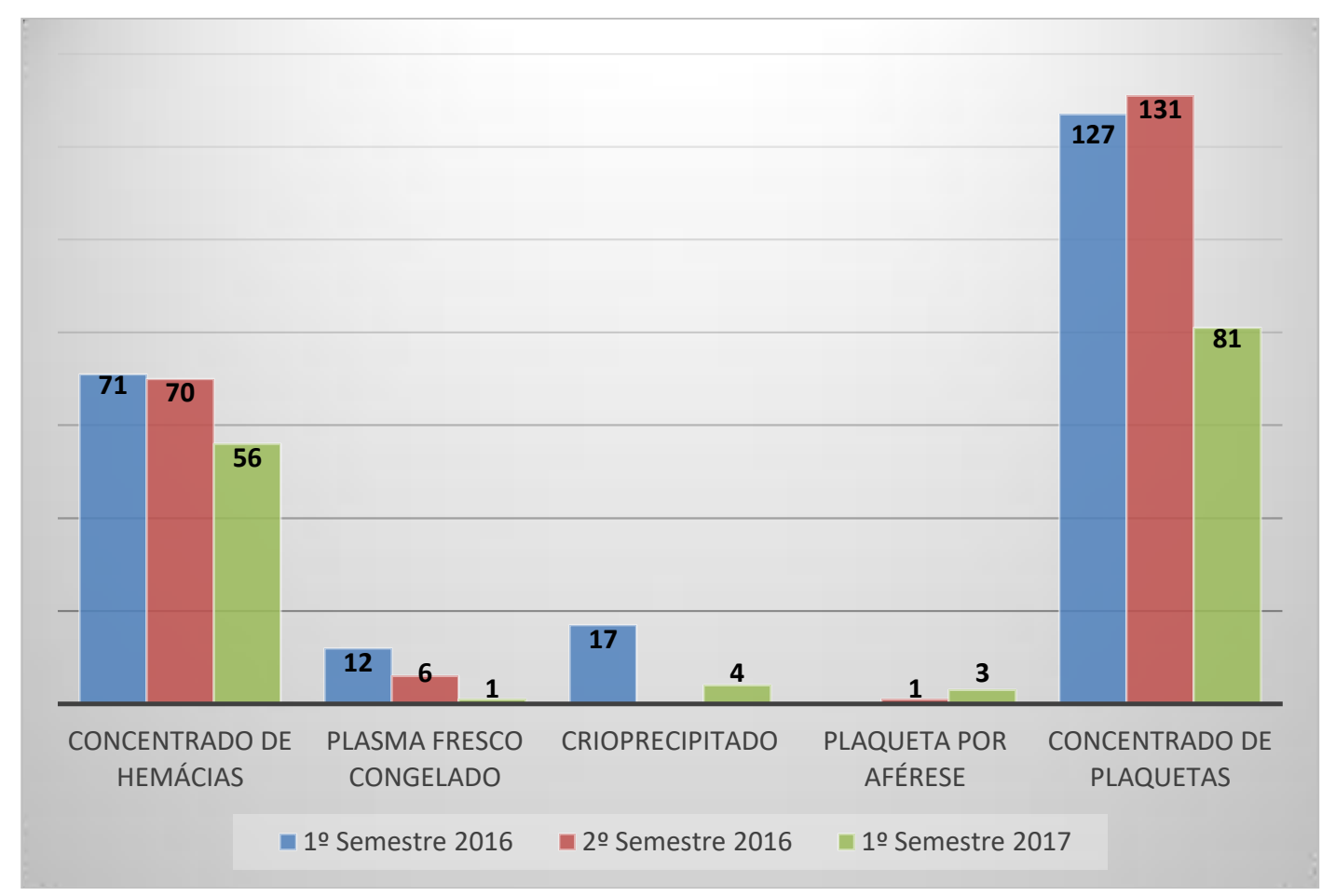

Fonte: resultados da pesquisa (2017). 
Figura 24 - Gráfico do índice de bolsas descartadas por vencimento

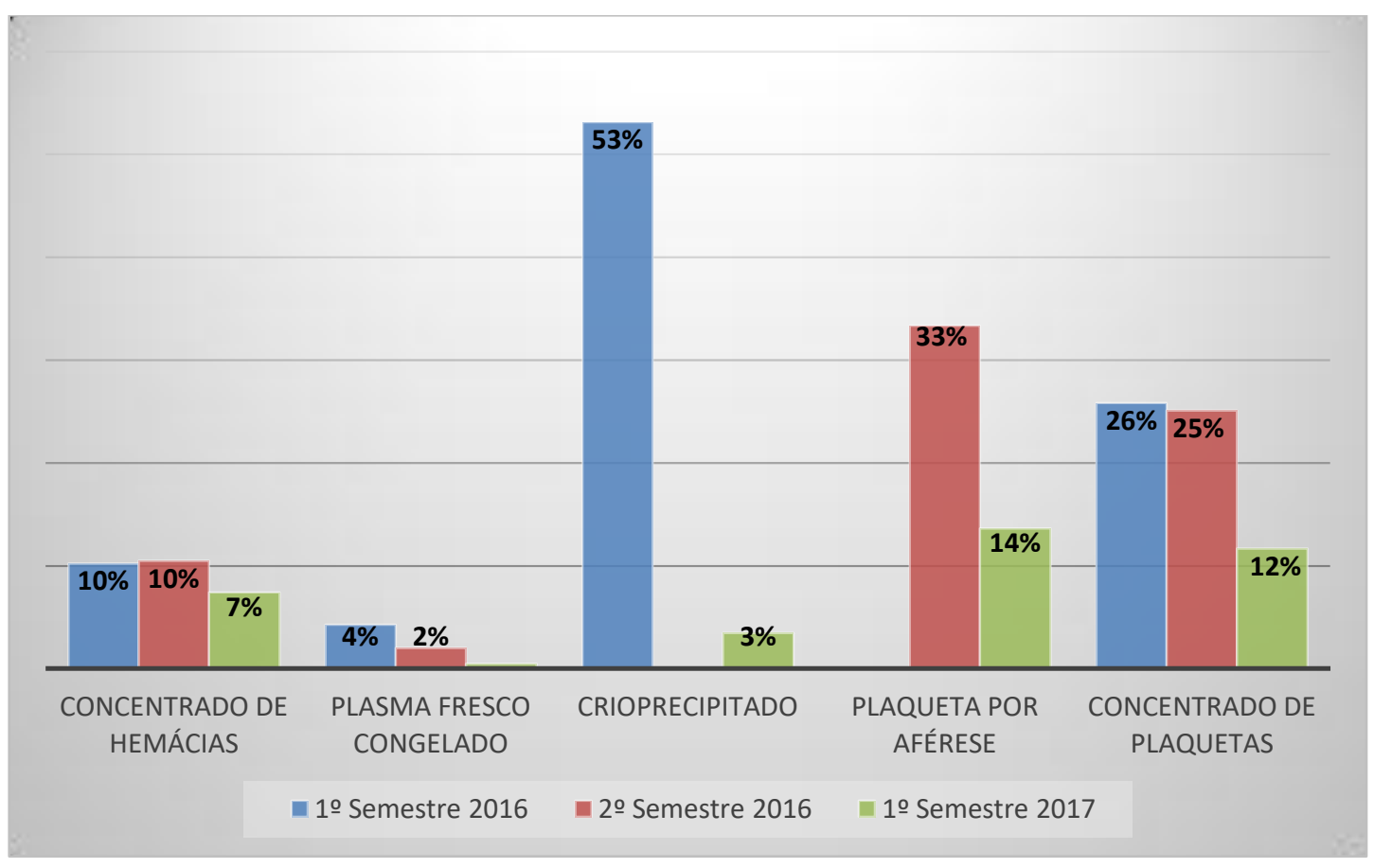

Fonte: resultados da pesquisa (2017).

\section{Indicador de bolsas descartadas por outros motivos:}

Este indicador monitora o descarte de bolsas por outros motivos, visando orientar ações que minimizem perdas. O hemocomponente mais descartado por este motivo foi o plasma fresco congelado. Em segundo lugar, foi o concentrado de hemácias.

Quando a quantidade de unidades descartadas é relacionada com as respectivas quantidades de unidades recebidas, em 2016, os mais descartados foram o plasma fresco congelado e o crioprecipitado. Já no 1ํsemestre de 2017, o plasma fresco congelado permaneceu em primeiro lugar, porém, seguido do concentrado de plaquetas aférese.

Os outros motivos de descarte quando referidos ao PFC e CRIO, seriam:

- Descongelamento (após o preparo do hemocomponente, ocorre o cancelamento da transfusão);

- Teste de qualidade (controle de qualidade interno); 
- Reprovação na inspeção visual (bolsa danificada (furada) ou aparência lipêmica);

Já os outros motivos de descarte quando referido ao Concentrado de Hemácia e Plaquetas, são:

- Abertura de sistema (principalmente nos casos de paciente pediátrico que veio a óbito ou está sem acesso para transfusão).

As Figuras 25 e 26 apresentam os resultados obtidos.

Figura 25 - Gráfico da quantidade de hemocomponentes descartados por outros motivos

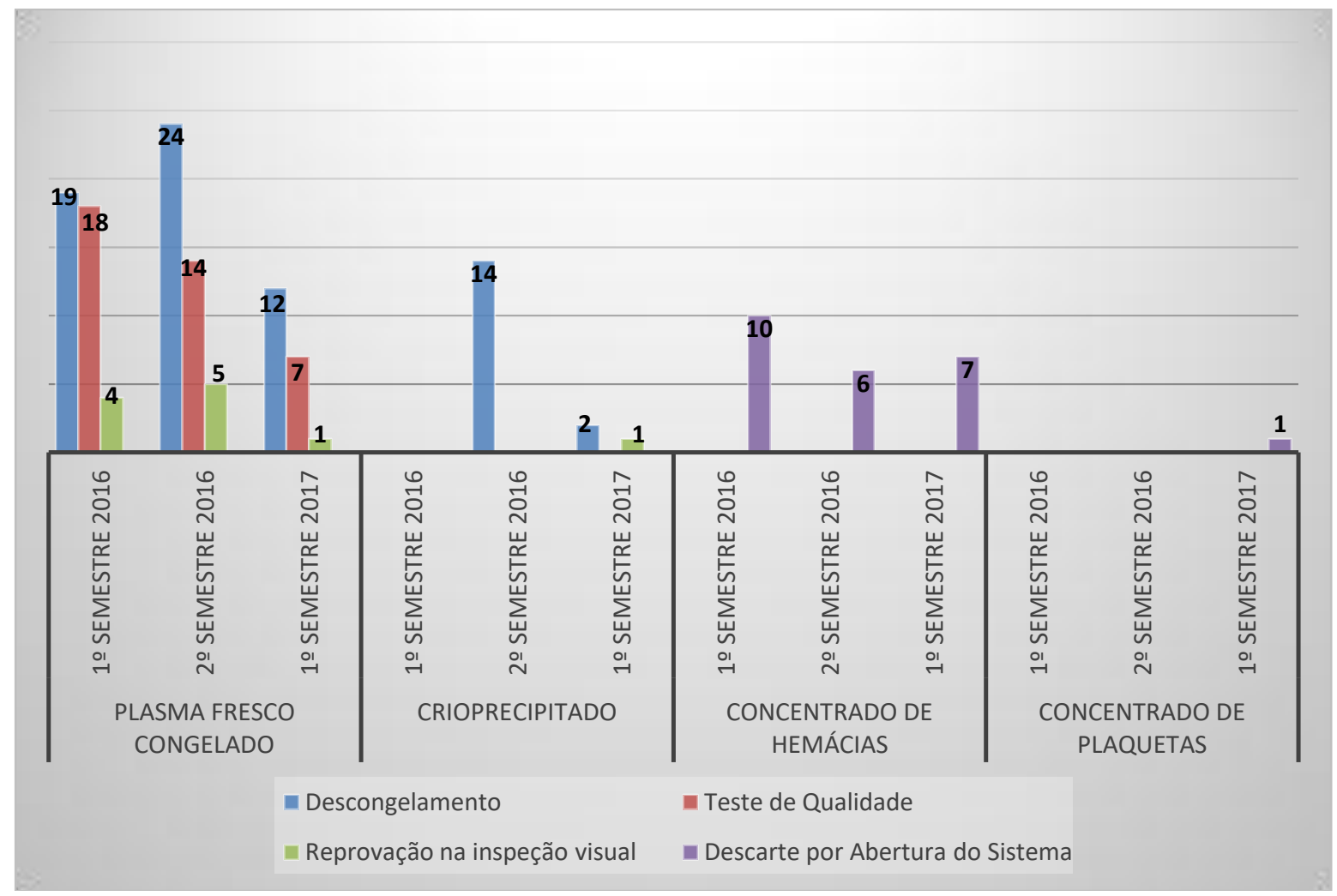

Fonte: resultados da pesquisa (2017). 
Figura 26 - Gráfico do índice de bolsas descartadas por outros motivos

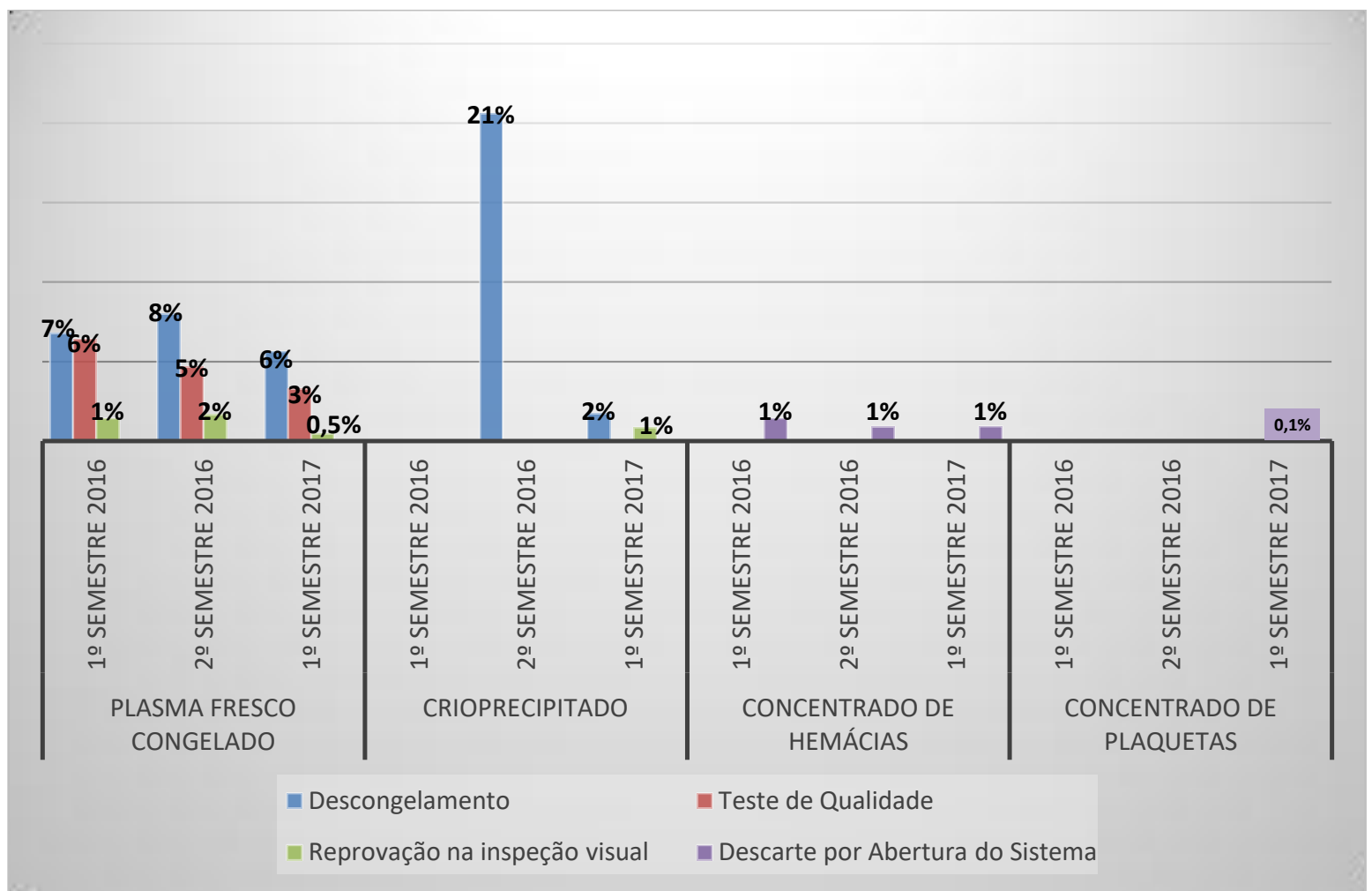

Fonte: resultados da pesquisa (2017).

\subsection{Manual para Agência Transfusional}

Além de possuir ênfase prática na implantação da qualidade, este estudo propõe a elaboração de um manual instrucional sobre os requisitos para o cumprimento das normativas vigentes nas agências transfusionais, tendo, como público-alvo, os profissionais que atuam na área da hemoterapia.

O Manual foi elaborado com o objetivo principal de apresentar uma descrição detalhada dos requisitos necessários para o funcionamento operacional de uma AT, com a descrição de diversos critérios que abrangem desde a estrutura e a organização de uma agência até $o$ ato transfusional.

As informações presentes neste Manual são amparadas por normas brasileiras (ANVISA - Agência Nacional de Vigilância Sanitária, MS - Ministério da Saúde) e americanas (AABB - American Association of Blood Banks) sobre as condutas hemoterápicas atuais.

O manual é apresentado através dos tópicos listados abaixo: 
Apresentação

1. Estrutura Física e Equipamentos

2. Contrato e Documentos exigidos

3. Recursos Humanos e Responsabilidade Técnica

4. Biossegurança e Gerenciamento de Resíduos

5. Gestão da Qualidade

6. Controle de Qualidade

7. Imunohematologia do Receptor

8. Ato transfusional

9. Comitê Transfusional, Hemovigilância e Retrovigilância

Referências Bibliográficas

De forma geral, a primeira parte do Manual, itens 1 a 3 , compõe-se de informações sobre as instalações, documentação necessária e recurso humanos de uma agência transfusional. Nesses itens são apresentados e descritos os requisitos sobre a área específica em que uma AT deve ser instalada, o controle de equipamentos que deve ser realizado, contratos e documentos para o funcionamento da AT, e gerenciamento do quadro de funcionários e responsável técnico.

Logo em seguida, o Manual descreve sobre as normas de biossegurança e participação do plano de gerenciamento de resíduos dos serviços de saúde (PGRSS), e nos itens 5 e 6 estão observados os requisitos sobre os princípios da qualidade, incluindo a atuação em um programa laboratorial de controle de qualidade interno e externo.

Nos itens 7 e 8 , que se refere a Imunohematologia do Receptor e ao Ato Transfusional, são evidenciados os requisitos necessários para realizar os testes pré-transfusionais e garantir a segurança na transfusão.

A última parte do Manual, expõe os requisitos de monitoramento da prática hemoterápica, em que a AT deve participar ativamente dos processos referentes ao Comitê Transfusional, Hemovigilância e Retrovigilância.

Para elaborar este Manual, foram observadas as literaturas, resoluções e portarias vigentes da área de hemoterapia e o roteiro de visita de qualificação de serviços de hemoterapia, aplicado para agência transfusional. 
O texto completo deste Manual encontra-se no Apêndice A e pretende servir de apoio não apenas aos profissionais que atuam em AT mas, também, aos gestores, coordenadores de hospitais e hemocentros, interessados na busca da qualidade de suas agências, servindo, assim, como uma importante ferramenta de gestão da qualidade, uma vez que preconiza toda a sistemática operacional e de funcionamento das agências transfusionais.

Por considerar as características do serviço e a legislação vigente, o Manual poderá ser um instrumento de consulta significativo, tanto para organização como para gestão das agências transfusionais no Brasil.

\subsection{Benefícios obtidos com a implantação da GQ}

Várias são as vantagens advindas da implantação da $\mathrm{GQ}$ em serviços de saúde. Na AT-HUJM, foi possível evidenciar muitas mudanças positivas. Atualmente, percebe-se que a agência está mais organizada, com processos de trabalho bem estabelecidos, padronizados e divulgados.

A definição de cargos e responsabilidades foi um benefício importante, assim como a padronização e o gerenciamento dos documentos, pois, com a existência de registros padronizados, obteve-se maior geração de dados e, consequentemente, de informações, facilitando, também, a organização do trabalho e a rastreabilidade dos dados obtidos.

O gerenciamento desses documentos proporcionou a garantia da utilização de documentação atualizada, o controle de revisões periódicas e o correto arquivamento dos mesmos.

A GQ da AT-HUJM, por meio da análise das não conformidades apontadas, possibilitou a identificação das causas dos problemas e a definição de estratégias corretivas e preventivas, contribuindo para uma melhoria dos processos de trabalho, evitando que novas ocorrências, de mesma causa, se repetissem.

A realização de auditorias internas, uma das ações implantadas com a $G Q$, possibilitou a verificação da adequação das não conformidades observadas frente às legislações vigente, permitindo que a AT pudesse realizar a correção de suas 
deficiências, gerando, assim, informações importantes que favoreceram 0 desempenho e a qualidade dos seus serviços e produtos.

O desenvolvimento de atividades de educações inicial e continuada também trouxe um benefício. A realização das capacitações proporcionou aos colaboradores momentos de aprendizagem e de troca de conhecimento. Estas capacitações contribuíram, sobretudo, para a melhoria da capacidade dos profissionais na análise crítica da equipe, em relação aos processos e às não conformidades. Com certeza, atualmente, o quadro funcional está melhor preparado tecnicamente.

Através da ouvidoria do HUJM, o recebimento e o tratamento das sugestões e críticas dos usuários, nortearam as mudanças e melhorias da AT, da mesma forma que as pesquisas de opinião e satisfação dos clientes, forneceram importantes informações que auxiliaram na tomada de decisões no serviço.

Com a melhoria da organização interna da AT e a implantação das ações anteriormente descritas, sua visão perante os demais setores e a direção do hospital subiu de nível, gerando aumento da confiança dos usuários na utilização dos serviços transfusionais.

Em dezembro de 2016, a agência foi um dos dois setores do hospital que receberam o selo interno "Implantando Qualidade", pelas ações desenvolvidas, durante todo o ano, no processo de implantação da Gestão da Qualidade. O selo foi entregue pelo superintendente do hospital para a responsável técnica e parte da equipe da agência transfusional. A Figura 27, mostra imagens do evento.

Figura 27 - Imagens da entrega do selo "Implantando Qualidade" para a AT- HUJM

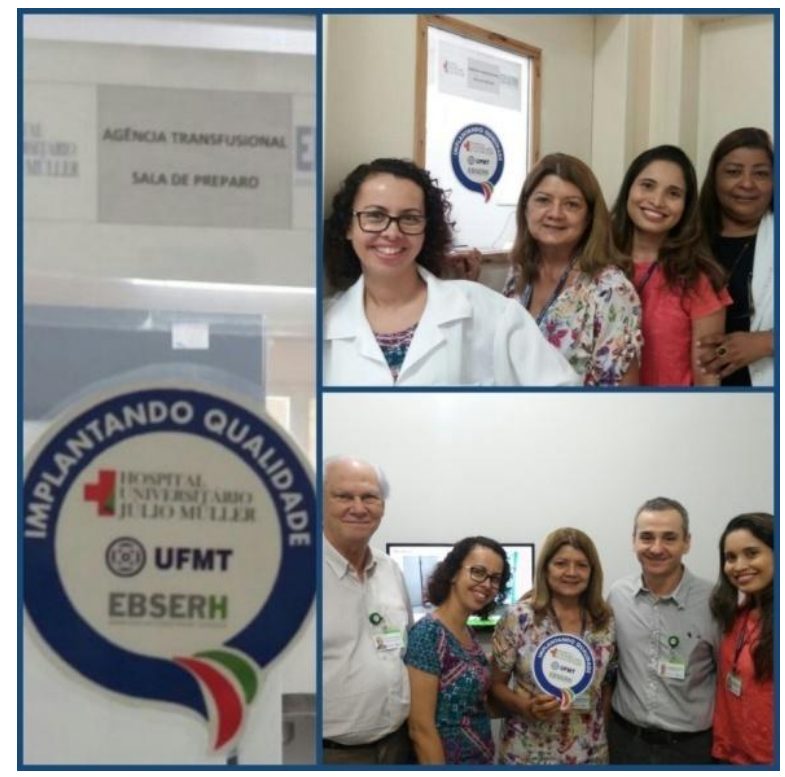

Fonte: da autora (2017). 
Em junho de 2017, a AT foi um dos destaques na rede intranet do HUJM, com uma matéria intitulada "Qualidade e Segurança São Atestados no Serviço de Hemoterapia", enfocando a melhora significativa no índice que mede o risco potencial em serviços de hemoterapia, nos últimos dois anos. A Figura 28 mostra uma imagem da citada rede.

Figura 28 - Imagem da rede intranet do HUJM, em junho de 2017

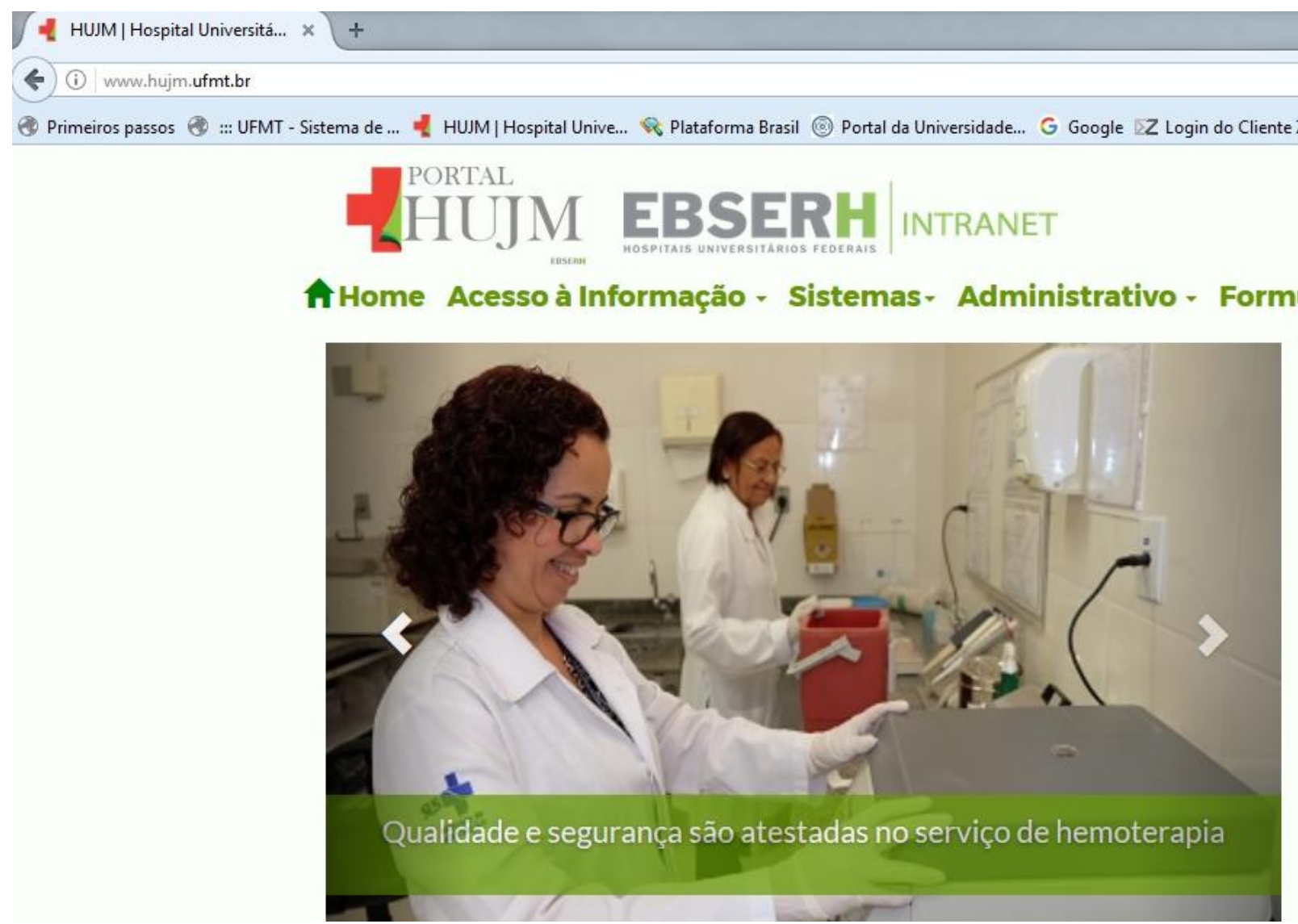

Fonte: Site HUJM, 2017.

O relatório de uma auditoria da Vigilância Sanitária de Cuiabá, de março de 2017, aponta que a AT-HUJM conta com $84,15 \%$ de segurança nos processos de transfusão de hemocomponentes realizados no hospital. A melhora foi apontada pela comparação com os $48,13 \%$ de segurança do relatório anterior, de junho de 2015. Em menos de dois anos, houve uma melhora de $75 \%$ nos processos de qualidade e segurança do serviço prestado.

Os gráficos mostrados na Figura 29 apresentam uma comparação detalhada dos números obtidos nessas duas auditorias. 
Figura 29 - Comparação dos resultados das inspeções da vigilância sanitária na AT- HUJM

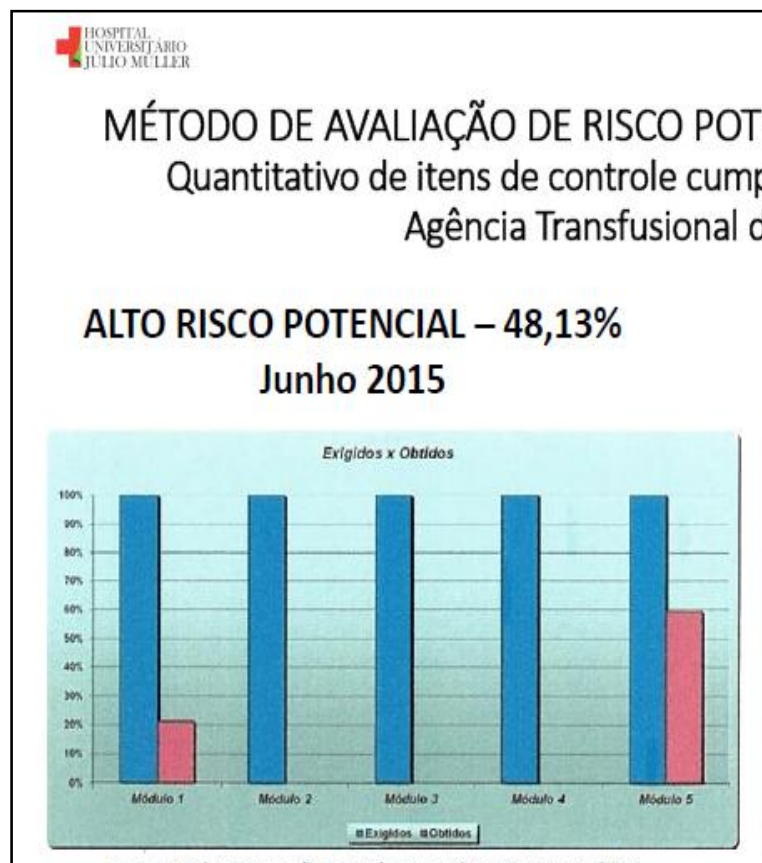

Fonte: Relatório de Inspeção da Vigilância Sanitária de 2015, Cuiabá-MT.

\section{EBSERH}

Foram avaliados os módulos 1 , 4 e 5

Módulo 1 - Geral

Módulo 2 - Captação, cadastro, triagem clínica, coleta total e aférese;

Módulo 3 - Triagem Laboratorial

Módulo 4 - Processamento, Armazenamento e Distribuição Hemocomponentes;

Módulo 5 - Testes pré-transfusional e Ato transfusional

Fonte: Documentos do HUJM (2017).

MÉDIO RISCO POTENCIAL - 84,15\% Março 2017

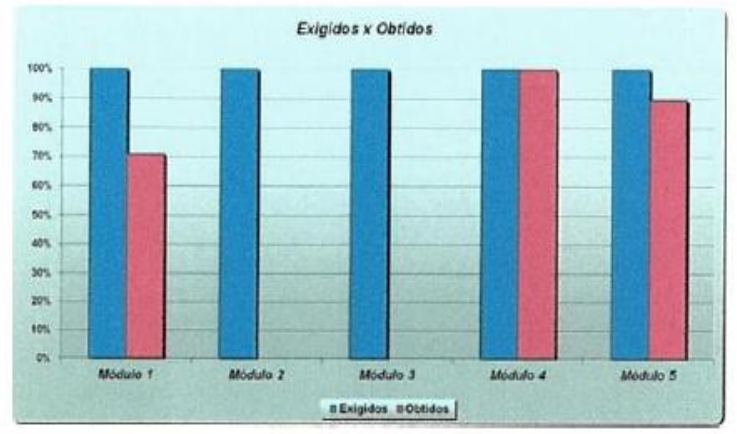

Fonte: Relatório de Inspeção da Vigilância Sanitária de 2017, Cuiabá-MT.

Considerando o disposto pelo artigo 229 da Portaria 05, anexo IV, "os registros referentes à doação e à transfusão serão, preferencialmente, informatizados" (BRASIL, 2017) e face às melhorias e novos registros implantados na AT-HUJM, observou-se a necessidade de se implantar um sistema informatizado para gerenciar e registrar os processos da AT. Assim, uma solicitação neste sentido foi enviada, oficialmente, ao Hemocentro coordenador, que encaminhou à Coordenação-Geral de Sangue e Hemoderivados, a adesão ao Sistema Hemovida Web Ciclo do Sangue - Módulo Agência Transfusional. Em seguida, foi enviado o relatório de redimensionamento para adesão ao sistema e, atualmente, estão sendo preparadas as ações necessárias para utilização prévia daquele sistema informatizado no ambiente de treinamento, enquanto se aguarda o agendamento para início de seu processo de implantação. Isto, certamente, será mais uma conquista da AT- HUJM rumo ao objetivo de melhorar, cada vez mais, seus processos de trabalho. 


\section{CONCLUSÃO}

As mudanças ocorridas com a estruturação da $G Q$ na $A T-H U J M$ contribuíram para o desenvolvimento de um setor mais organizado e bem preparado para garantir a qualidade de seus serviços e produtos. Dentre as mudanças positivas, merecem destaque: a identidade organizacional foi caracterizada, os processos internos estão mais bem definidos e otimizados, e mais dados são gerados para auxiliarem na tomada de decisões.

A identificação das rotinas realizadas na AT-HUJM, através da análise dos processos e criação dos POP's, Manuais e Protocolos, foram de grande importância para conscientização da equipe de trabalho, mostrando que, fortalecer o processo de gestão da qualidade, significa aproximar as áreas técnicas e estratégicas dentro do serviço. As ações desencadearam atitude proativa nos colaboradores envolvidos com o processo, que passaram a preocupar-se com qualidade.

Nesse contexto, para viabilizar a gestão da qualidade na AT-HUJM, houve a necessidade de reestruturação das instalações físicas, de segurança e cuidado ao paciente e colaborador. Por intermédio do Comitê Transfusional, houve apoio da direção do hospital e dos gerentes das equipes assistenciais, para investimento na gestão da infraestrutura, materiais e equipamentos da agência, constituindo medidas práticas de melhorias, além da realização de treinamentos internos com a equipe multiprofissional do hospital envolvida diretamente nos processos da AT. Cumprimento das boas práticas, atualização dos profissionais e implantação da gestão da qualidade são marcos na garantia da qualidade.

A definição e a aplicação dos indicadores de qualidade da AT-HUJM foram desenvolvidas através dos conhecimentos adquiridos pela troca de informações do processo de benchmarking com Hemocentro-RP. Foi necessário difundir entre os colaborados, os conceitos e a importância dos indicadores na gestão dos processos e avaliação do desempenho do serviço.

Para a elaboração de um manual com objetivo instrucional, aplicável a qualquer agência transfusional, foram realizadas consultas à literatura, resoluções e portarias vigentes da área de hemoterapia. O texto completo do manual, no Apêndice, e tem como finalidade orientar os profissionais que atuam em agências 
transfusionais, oferecendo uma importante ferramenta de gestão da qualidade, uma vez que preconiza toda a sistemática operacional e de funcionamento das agências transfusionais. E poderá ser uma ferramenta importante tanto na organização como na gestão das agências transfusionais no Brasil.

Já é possível perceber o resultado deste trabalho em prol da qualidade que vem sendo desenvolvida na AT-HUJM que, no final de 2016, recebeu o selo interno de "Implantando Qualidade" do HUJM e, em 2017, após visita da vigilância sanitária, virou notícia na intranet do hospital.

Essas conquistas são importantes reconhecimentos à atuação da AT-HUJM, servindo como uma grande motivação para toda a equipe que vem realizando um trabalho técnico comprometido e qualificado.

Implantar a GQ na AT-HUJM, através de um benchmarking com o Hemocentro-RP, foi de grande relevância para elucidar as questões de como iniciar o processo de gestão no serviço de hemoterapia. As informações obtidas no serviço de referência, auxiliaram diretamente na aplicação da rotina, obtendo um avanço na qualidade da agência.

Face ao exposto, por implantar a gestão da qualidade na instituição observase que a AT-HUJM ganhou em organização e qualidade, efetivando um setor responsável, onde todas as ações desenvolvidas contribuem para a adequação e a segurança transfusionais.

Este estudo apresentou limitações importantes quanto à busca de informações sobre indicadores de qualidade na área da medicina transfusional, pois são poucos os artigos encontrados na literatura, por ser um tema ainda recente para a área, principalmente quando se fala da comparabilidade de dados ou benchmarking.

Dentre os obstáculos enfrentados, alguns foram vencidos, como o aumento de atividades e responsabilidades dos colaboradores da AT-HUJM. Outros ainda não, como a contratação de recursos humanos, os serviços de manutenção preventiva para alguns equipamentos e a informatização dos processos.

Como perspectivas futuras para a AT-HUJM, sugerem-se a continuidade do desenvolvimento das ações da qualidade e, principalmente, a implantação de um sistema informatizado, visando se tornar um serviço de referência no segmento hemoterápico e servir de modelo para outras AT do estado de Mato Grosso. 


\section{REFERÊNCIAS}

AABB. Quality Management Systems: Theory and Practice. In: ROBACK, J. D. Technical Manual. 18. ed. Bethesda: American Association of Blood Banks, 2014. Cap. 1, p. 1-39

ANDRADE NETTO, C. A. Proposta de Modelo de Mapeamento e Gestão por Processos. 2004. 146f. Tese (Doutorado em Engenharia) - Departamento de Engenharia de Produção, Escola Politécnica da Universidade Federal de São Paulo, São Paulo, 2004.

ASSOCIAÇÃO BRASILEIRA DE NORMAS TÉCNICAS. NBR ISO 9000:2005 Sistemas de gestão da qualidade - Fundamento e vocabulário. Rio de Janeiro, 2005.

NBR ISO 9001:2015 - Sistemas de gestão da qualidade - Requisitos. 66p. 2015a. Rio de Janeiro, 2015.

ANTUNES, E. A.; NASCIMENTO, F.; RODRIGUES, F.; DURAN, J. Á.;

FIGUEIREDO, M.; AMIL, M. et al. Imuno-hematologia: recomendações. Lisboa: Instituto Português do Sangue; 2008.

BITTAR, O. J. N. V. Indicadores de qualidade e quantidade em saúde. Rev. Adm. Saúde, v. 3, n. 12, p. 21-8, 2001,2001.

BITTAR, O. J. N.; QUINTO NETO, A. Hospitais: administração da qualidade e acreditação de organizações complexas. Porto Alegre, p. 185-192, 2004.

BOGAN, C.; ENGLISH, M. J. Benchmarking, aplicações práticas e melhoria contínua. Makron Books, 1997.

BONATO, V. L. Gestão da Qualidade em Saúde: melhorando a assistência ao cliente. O Mundo da Saúde, São Paulo, v. 35, n. 5, p. 319-331, 2011.

BRASIL. Ministério da Saúde. Programa da qualidade do sangue (PQS) Instrumento de autoavaliação dos órgãos executores das atividades hemoterápicas. Brasília, 1999.

BRASIL. Ministério da Saúde. Resolução RDC no 151, de 21 de Agosto de 2001. Aprova o Regulamento Técnico sobre Níveis de Complexidade dos Serviços de Hemoterapia, que consta como anexo. Diário Oficial [da] República Federativa do Brasil, Poder Executivo, Brasília, DF, 22 ago. 2001.

BRASIL. Ministério da Saúde. Resolução RDC nำ 466, de 12 de Dezembro de 2012. Aprova as diretrizes e normas regulamentadoras de pesquisas envolvendo seres humanos. Diário Oficial [da] República Federativa do Brasil, Poder Executivo, Brasília, DF, 13 jun. 2013. 
BRASIL. Ministério da Saúde. Resolução RDC no 34, de 11 de Junho de 2014. Dispõe sobre as Boas Práticas no Ciclo do Sangue. Diário Oficial [da] República Federativa do Brasil, Poder Executivo, Brasília, DF, 16 jun. 2014.

BRASIL. Agência Nacional de Vigilância Sanitária. Marco Conceitual e Operacional de Hemovigilância: Guia para a hemovigilância no Brasil. Brasília: Agência Nacional de Vigilância Sanitária/ANVISA, 2015. Disponível em: <http://portal.anvisa.gov.br/documents/33868/404938/guia_hemovigilancia15.pdf/495 fd617-5156-447d-ad22-7211cdbab8a7>. Acesso em: 15 set. 2016.

BRASIL. Ministério da Saúde. Portaria de Consolidação no 5, de 03 de Outubro de 2017. Consolidação das normas sobre as ações e os serviços de saúde do Sistema Único de Saúde. Anexo IV - Do sangue, componentes e derivados. Diário Oficial [da] República Federativa do Brasil, Poder Executivo, Brasília, DF, 03 out. 2017. Seção 1, p. 222-353.

CAMP, R. C. Benchmarking: o caminho da qualidade total. São Paulo: Pioneira, v. 3, 1998.

CAMPOS, M.M.; SANTOS, I.R. Gestão de risco em medicina transfusional: modelos e ferramentas. Revista portuguesa de Saúde Pública, v. 28, n. 2, p. 155-160, 2010.

CARDOSO, J.C.; LUZ, A. R. Os arquivos e os sistemas de gestão da qualidade. Revista Arquivo \& Administração, v. 3, p. 51-64, 2004.

DEMING, W. E. Qualidade: A Revolução da Administração. Rio de Janeiro: Editora Marques Saraiva S.A., 1990. 365p.

GALORO, C. A. O.; MENDES, M. E.; BURATTINI, M. N. Applicability and potential benefits of benchmarking in Brazilian clinical laboratory services. Benchmarking: An International Journal, v. 16, n. 6, p. 817-830, 2009.

GIRARDELLO, M. Gestão da Qualidade em Saúde: o caso do Hemocentro Regional de Caxias do Sul - RS. 2015. 47f. Monografia (Especialização em Gestão em Saúde) - Escola de Administração, Universidade Federal do Rio Grande do Sul, Novo Hamburgo, 2015.

JUNQUEIRA, P. C.; ROSENBLIT, J.; HAMERSCHLAK, N. History of Brazilian hemotherapy. Revista brasileira de Hematologia e Hemoterapia, v. 27, n. 3, p. 201 207, 2005.

KURCGANT, P.; LEITE, M. M.; PEREIRA, L. L. Educação continuada em enfermagem. Administração em enfermagem. São Paulo: EPU, p. 147-63, 1991.

MAINZ, J. Defining and classifying clinical indicators for quality improvement. International Journal for Quality in Health Care, v. 15, n. 6, p. 523-530, 2003. 
MALIK, A. M.; SCHIESARI, L. M. C. Qualidade na gestão local de serviços e ações de saúde. IDS/FSP/USP/Banco Itaú, 1998.

MENDES, M. E. Avaliação da implantação de um sistema de qualidade em um laboratório clínico público. 1998. 202 f. Tese (Doutorado em Medicina) Faculdade de Medicina, Universidade de São Paulo, São Paulo, 1998.

MOORE, S.B.; FOSS, M.L. Error Management. Archives of Pathology \& Laboratory Medicine, v. 127, p. 1517-1522, 2003.

MOURA, G. M. S. S. et al. Construção e implantação de dois indicadores de qualidade assistencial de enfermagem. Revista gaúcha de enfermagem. Porto Alegre. Vol. 30, n. 1 (mar. 2009), p. 136-140, 2009.

OLIVEIRA, O. Gestão da Qualidade: introdução à história e fundamentos. Gestão da Qualidade: tópicos avançados. São Paulo: Pioneira Thomson Learning, p. 3-20, 2004.

PLEBANI, M. Exploring the iceberg of errors in laboratory medicine. Clinica chimica acta, v. 404, n. 1, p. 16-23, 2009.

RICÓS, C.; GARCI'A-VICTORIA, M.; DE LA FUENTE, B. Quality indicators and specifications for the extra-analytical phases in clinical laboratory management. Clinical Chemistry and Laboratory Medicine (CCLM), v. 42, n. 6, p. 578-582, 2004.

SCIACOVELLI, L. et al. Risk management in laboratory medicine: quality assurance programs and professional competence. Clinical Chemistry and Laboratory Medicine (CCLM), v. 45, n. 6, p. 756-65, 2007.

SOUZA, M. A. Análise Comparativa dos Indicadores de Qualidade Implantados nos Hemocentros de Referência do Brasil. 2013. 108f. Monografia

(Especialização em Gestão em Saúde e Controle de Infecção) - Faculdade INESP. Florianópolis, 2013.

TAKAKURA V. F. Benchmarking nos Processos de Gestão da Qualidade Entre Dois Serviços de Hemoterapia. 2011. 67f. Dissertação (Mestrado em Biotecnologia Médica) - Faculdade de Medicina de Botucatu, Botucatu, 2011.

VIEIRA, K. F.; SHITARA, E. S.; MENDES, M. E.; SUMITA, N. M. A utilidade dos indicadores da qualidade no gerenciamento de laboratórios clínicos. Jornal

Brasileiro de Patologia e Medicina Laboratorial, v. 47, n. 3, p. 201-210, 2011. 
APÊNDICE - MANUAL PARA AGÊNCIA TRANSFUSIONAL

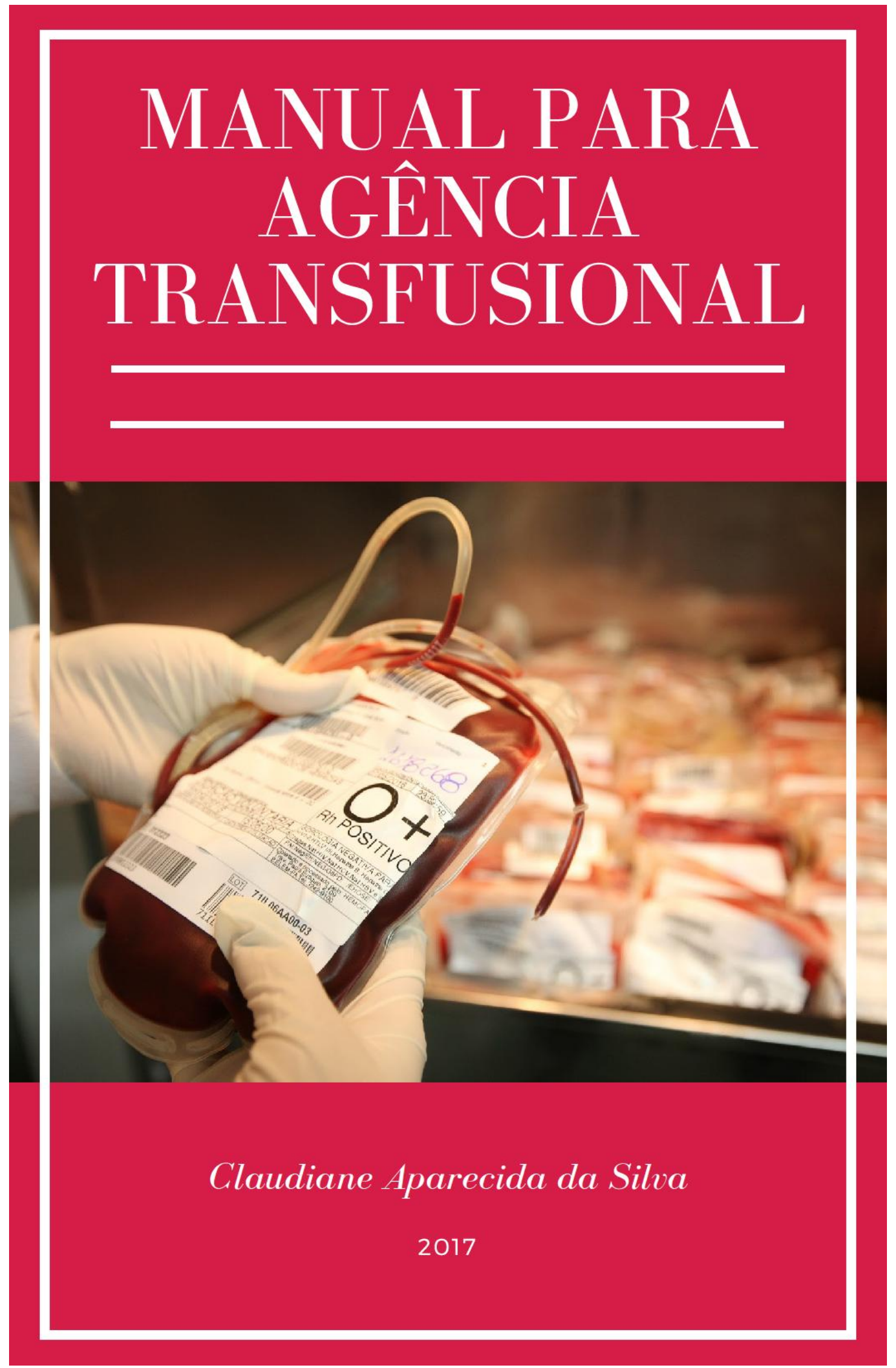




\section{APRESENTAÇÃO}

A saúde brasileira e sua prática nos dias atuais exigem excelência técnica, organizacional e prática humanizada. O não cumprimento dessas exigências pode levar prejuízos aos pacientes, aos profissionais da saúde e à instituição onde se realiza a assistência.

As informações técnicas em medicina transfusional são frequentemente atualizadas, mediante $o$ avanço científico nacional e internacional, sendo contemplado também nas regulamentações nacionais. As normativas referentes ao sangue remetem à legislação federal específica, e o seu não cumprimento pode acarretar medidas legais cabíveis.

Agência Transfusional é uma unidade de localização geralmente intrahospitalar que armazena, realiza testes de compatibilidade entre doador e receptor e transfunde os hemocomponentes liberados. Seu suprimento de hemocomponentes é feito, mediante contrato, por um serviço de maior complexidade. É responsável por manter registros relativos aos testes e as transfusões realizadas garantindo a rastreabilidade dos hemocomponentes recebidos e transfundidos incluindo o vínculo entre o hemocomponente e o receptor, bem como, das unidades descartadas. Pode ser classificada como tipo I quando possui área física específica, equipamentos, pessoal qualificado e estoque de hemocomponentes; e do tipo II ou "Atendimento à distância", que não possui estoque de hemocomponentes e é atendida por um serviço de hemoterapia à distância, que recebe a amostra do paciente e realiza os testes pré-transfusionais. A legislação vigente preconiza que "as instituições de assistência à saúde que realizem intervenções cirúrgicas de grande porte, atendimentos de urgência e emergência ou que efetuem mais de 60 transfusões por mês devem contar com, pelo menos, uma Agência Transfusional" (BRASIL, 2016).

O presente Manual tem como finalidade orientar os profissionais que atuam em agências transfusionais, oferecendo uma importante ferramenta de gestão da qualidade, uma vez que preconiza toda a sistemática operacional e de funcionamento das agências transfusionais. 


\section{SUMÁRIO}

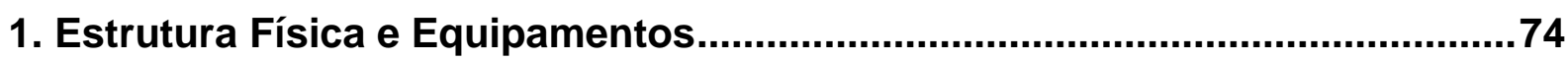

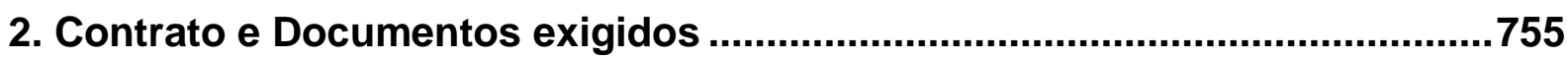

3. Recursos Humanos e Responsabilidade Técnica.........................................766

4. Biossegurança e Gerenciamento de Resíduos ............................................777

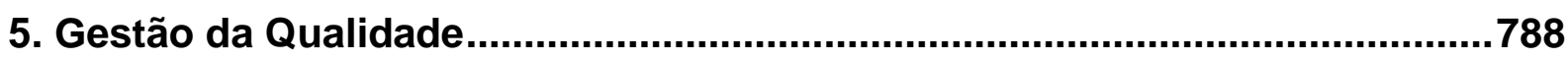

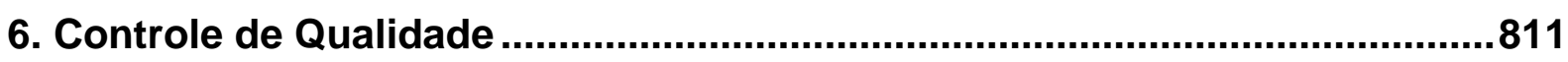

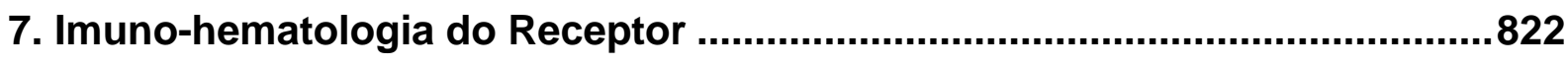

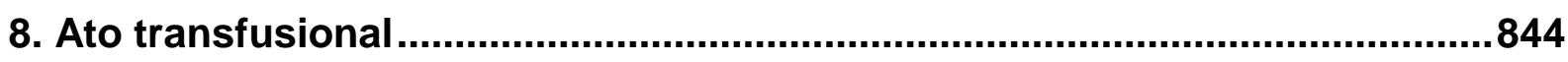

9. Comitê Transfusional, Hemovigilância e Retrovigilância ..............................866

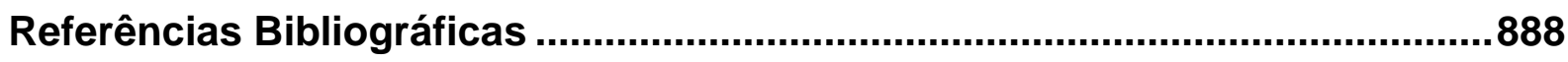




\section{Estrutura Física e Equipamentos}

As instalações de uma Agência Transfusional requerem, antes de sua preparação, a aprovação do SVS - Serviço de Vigilância Sanitária da localidade onde será instalada. Deve possuir os seguintes requisitos:

$\checkmark$ Possuir área específica com fluxo e iluminação adequados para execução das atividades.

$\checkmark$ Realizar adequada de limpeza, conservação e manutenção predial com registros atualizados.

$\checkmark$ Apresentar ambientes, salas e setores identificados e ou sinalizados de acordo com as normas de biossegurança e de saúde do trabalhador.

$\checkmark$ Possuir adequado controle de temperatura dos ambientes.

$\checkmark$ Realizar controle de vetores adequado e seguro, contendo proteção contra entrada de insetos e roedores.

A Agência Transfusional deve ter processos para assegurar a calibração, manutenção, monitoramento e controle dos equipamentos utilizados. Deve atender os itens abaixo relacionados:

$\checkmark$ Possuir adequado controle de temperatura dos equipamentos que armazenam reagentes e hemocomponentes, dentro dos limites estabelecidos, em intervalos regulares e com registro em mapas de controle devidamente preenchidos e gerenciados.

$\checkmark$ Possuir refrigeradores e congeladores com sistema de alarme configurado para ser ativado sob condições que permitam que a ação apropriada seja tomada antes que os hemocomponentes alcancem condições inaceitáveis.

$\checkmark$ Possuir banho-maria próprio com temperatura adequada, para descongelar plasma fresco congelado e crioprecipitado, com devida proteção das bolsas.

$\checkmark$ Possuir manuais e/ou instruções escritas de operação dos equipamentos, incluindo manuseio e limpeza.

$\checkmark$ Registrar a manutenção preventiva e calibração periódica dos equipamentos específicos para as atividades realizadas. 


\section{Contratos e Documentos exigidos}

Os contratos para fornecimento de hemocomponentes e realização de exames poderão ser estabelecidos mediante a manifestação formal da Instituição Hospitalar, conforme Art. 273 da Portaria MS № 158/2016 - Regulamento Técnico de Procedimentos Hemoterápicos, acompanhado dos documentos listados abaixo:

Art. 273. O serviço de hemoterapia que distribui componentes sanguíneos para estoque formalizará por escrito com o serviço de hemoterapia receptor, um contrato, convênio ou termo de compromisso, no qual constarão:

I - nomes e dados jurídicos das instituições envolvidas;

II - responsabilidades técnicas e financeiras de cada uma das partes, respeitando-se todas as normas técnicas constantes desta Portaria;

III - responsabilidade pelo transporte adequado do sangue e seus componentes;

IV - penalidades para o não cumprimento das obrigações; e

$V$ - vigência.

Documentos Necessários:

- Contrato Social da Instituição Hospitalar (em vigor);

- Cadastro do CNPJ;

- CPF e RG do Responsável pela Instituição Hospitalar;

- Alvará expedido pelo SVS da Instituição Hospitalar;

- Alvará expedido pelo SVS da Agência Transfusional;

- Termo de Responsabilidade Técnica;

- CPF e RG do Responsável Técnico.

$\checkmark$ A Agência Transfusional deve possuir alvará de funcionamento atualizado fornecido pela Vigilância Sanitária local. Caso o alvará seja do hospital, verificar se ele contempla a agência transfusional. 


\section{Recursos Humanos e Responsabilidade Técnica}

A Agência Transfusional deve possuir um quadro de funcionários qualificados por formação, treinamento e/ou experiência, e atender aos requisitos:

$\checkmark$ Possuir recursos humanos em número suficiente para as atividades e devidamente treinados, com avaliação de eficácia dos treinamentos.

$\checkmark$ Possuir plano de educação e treinamento dos profissionais, incluindo treinamento inicial e continuado com avaliação da eficácia dos mesmos e levantamento das necessidades.

$\checkmark$ Possuir prática de acolhimento e ambientação para novos profissionais que atuarão no serviço.

$\checkmark$ Identificar adequadamente todos os colaboradores da instituição por meio do uso do crachá e controle por setor e cargo.

$\checkmark$ Apresentar Programa de Saúde Ocupacional (PPRA - Programa de Prevenção de Risco Ambiental e PC-MSO - Programa de Controle Médico de Saúde Ocupacional) implementado e adequado.

$\checkmark$ Realizar exames periódicos e calendário vacinal conforme programa nacional de imunização.

$\checkmark$ Possuir arquivo (pasta) funcional para cada funcionário, inclusive para estagiário e terceirizado (quando houver);

$\checkmark$ Apresentar responsabilidades de cada profissional, definidas e atualizadas em um documento com descrição de cargos.

$\checkmark$ Apresentar profissionais orientados quanto ao setor de lotação e responsabilidades do cargo no momento da admissão, com registros adequados.

$\checkmark$ Estar sob responsabilidade técnica de profissional médico, especialista em hemoterapia ou hematologia, ou qualificado por órgão competente devidamente reconhecido para este fim pelo Sistema Estadual de Sangue, que responderá pelas atividades executadas pelo serviço.

$\checkmark$ Contar com outro profissional médico treinado para ser o Responsável Técnico substituto. 


\section{Biossegurança e Gerenciamento de Resíduos}

A Agência Transfusional deve informar e conscientizar a importância das normas de biossegurança aos colaboradores, seguindo os itens abaixo:

$\checkmark$ Possuir manual ou procedimento operacional sobre biossegurança, próprio ou do estabelecimento de saúde.

$\checkmark$ Orientar e prover aos funcionários os equipamentos de proteção individuais (EPI's) adequados às atividades que executam.

$\checkmark$ Ter disponibilidade de equipamentos de proteção coletiva (EPC), por exemplo, cabine de segurança biológica classe II, conforme legislação vigente.

$\checkmark$ Ter áreas de trabalho limpas e livres de obstruções.

$\checkmark$ Possuir práticas de limpeza e descontaminação das superfícies de trabalho após derramamento de materiais perigosos e ao final do dia de trabalho.

$\checkmark$ Possuir práticas de descarte dos materiais perfurocortantes (agulhas, lancetas, vidraria quebrada, outros) em recipientes destinados para este fim E orientar jamais reencapar, entortar ou cortar agulhas.

$\checkmark$ Ao manipular sangue, material biológico, controles, soros e antissoros, proceder como potencialmente contaminados, mesmo que não haja referência específica sobre os riscos em tais materiais.

$\checkmark$ Não armazenar alimentos ou alimentar-se nos ambientes laboratoriais.

Manter cabelos presos e não utilizar adereços.

A Agência Transfusional deve participar do plano de gerenciamento de resíduos dos serviços de saúde (PGRSS) do hospital, seguindo, rigorosamente as legislações vigentes. Além disso, deve:

$\checkmark$ Treinar e orientar a correta segregação dos resíduos.

$\checkmark$ Realizar o descarte adequado dos materiais e hemocomponentes com os devidos controles e registros. 


\section{Gestão da Qualidade}

A Agência Transfusional deve implantar ou participar de um sistema de gestão da qualidade, próprio ou da instituição a que pertence, como intuito de estabelecer um conjunto de políticas e procedimentos para adequar seus processos aos princípios da qualidade e às legislações vigentes, garantindo a qualidade dos produtos e serviços prestados aos pacientes. Para isso, além dos requisitos já referidos sobre instalações e recursos humanos, podem-se destacar os seguintes:

\section{Organizacão e lideranç:}

$\checkmark$ Possuir organograma com as responsabilidades definidas.

\section{Foco no cliente:}

$\checkmark$ Possuir programa de segurança do paciente implantado, inclusive com os indicadores aplicáveis conforme legislação vigente.

$\checkmark$ Possuir sistemática de reclamações e sugestões para clientes/usuários adequada e segura, própria ou do estabelecimento de saúde em que está instalada.

\section{Gestão de fornecedores e materiais:}

$\checkmark$ Definir lista de materiais críticos e qualificar fornecedores para que atendam de forma consistente aos requisitos especificados pela agência transfusional.

\section{Gestão de equipamentos:}

$\checkmark$ Identificar os equipamentos críticos para o funcionamento da agência transfusional e assegurar que sua calibração, manutenção, monitoramento e controle estejam de acordo com os padrões e os requisitos especificados pela agência transfusional.

\section{Gestão de processos:}

$\checkmark$ Realizar validação dos processos considerados críticos para a garantia da qualidade dos produtos e serviços, incluindo processos referentes a equipamentos e instrumentos.

$\checkmark$ Realizar transporte dos hemocomponentes em recipientes e caixas adequadas utilizando processos validados. 
$\checkmark$ Garantir treinamento dos profissionais responsáveis pela execução do transporte de hemocomponentes, quanto às condições de transporte e às ações a serem tomadas em eventuais intercorrências.

\section{Documentos e registros:}

$\checkmark$ Apresentar documentação com conteúdo adequado, aprovado e assinado por pessoal capacitado e autorizado que permita rastreabilidade em todo 0 processo, desde a obtenção até o destino final do produto.

$\checkmark$ Realizar gestão de documentos de forma que garanta a disponibilidade da versão vigente nas áreas, com definição dos responsáveis pela aprovação dos mesmos, controle de alterações e treinamento dos envolvidos na versão atual dos documentos.

$\checkmark$ Possuir sistema de informação eletrônico ou em papel que garanta $o$ funcionamento contínuo do atendimento de maneira segura.

$\checkmark$ Realizar a guarda de documentos do serviço adequadamente e com segurança.

$\checkmark$ Garantir o sigilo das informações conforme normas e legislações vigentes.

$\checkmark$ Gestão de eventos não conformes e melhoria de processos

$\checkmark$ Registrar e gerenciar indicadores de acompanhamento, desvios, quaseerros, não conformidades, ações corretivas e ações preventivas/de melhoria.

$\checkmark$ Realizar análise e gerenciamento adequado dos relatórios de inspeção da Vigilância Sanitária e/ou auditorias externas e internas.

\section{Auditorias:}

$\checkmark$ Realizar auditoria interna para verificação do cumprimento dos requisitos, com registros adequados para documentar seus resultados e os planos de ação.

\section{Melhoria de processos:}

$\checkmark$ Possuir procedimento operacional para cada etapa dos processos com detalhamento das atividades realizadas, insumos e especificação dos equipamentos e instrumentos utilizados, normas de segurança e responsáveis pela execução das atividades.

$\checkmark$ Possuir procedimentos operacionais adequados, adaptados à rotina local, disponíveis no setor, atualizados e revistos no mínimo uma vez por ano. 
$\checkmark$ Apresentar procedimentos operacionais com descrição detalhada das atividades e realizar sua avaliação sistemática com registros e histórico das alterações realizadas. 


\section{Controle de Qualidade}

A Agência Transfusional deverá estabelecer um programa laboratorial de controle de qualidade interno e participar de programa laboratorial de controle de qualidade externo (testes de proficiência), com objetivo de assegurar que os procedimentos sejam apropriadamente executados e que os equipamentos, materiais e reagentes funcionem corretamente, seguindo os requisitos:

$\checkmark$ Utilizar procedimentos técnicos e reagentes adequados à rotina de trabalho, incluindo controle de qualidade dos reagentes utilizados.

$\checkmark$ Garantir respeito aos prazos de validade dos reagentes utilizados;

$\checkmark$ Realizar controle de qualidade do lote de reagente em uso.

$\checkmark$ Realizar a validação de cada lote dos reagentes antes de liberar para uso na rotina.

$\checkmark$ Realizar gerenciamento, realização e registro do controle de qualidade externo e interno.

$\checkmark$ Realizar e gerenciar a execução e os resultados dos controles de qualidade interno (amostras cegas ou conhecidas);

$\checkmark$ Realizar e gerenciar a execução e os resultados dos controles de qualidade externo (desempenho do serviço nos três últimos CQE realizados).

$\checkmark$ Realizar validação dos processos de trabalho.

$\checkmark$ Utilizar técnicas, reagentes e equipamentos seguros e adequados à rotina de trabalho.

$\checkmark$ Realizar armazenamento adequado dos reagentes e amostras.

$\checkmark$ Controlar os reagentes utilizados na realização dos testes de controle de qualidade (marca, lote, validade, etc.).

$\checkmark$ Realizar controles de qualidade em cada lote e remessa recebidos para comprovar que os reagentes estão dentro dos padrões estabelecidos e que não foram alterados durante o transporte. 


\section{Imuno-hematologia do Receptor}

Os testes pré-transfusionais têm o objetivo de garantir a escolha do melhor hemocomponente para cada receptor, atendendo aos seguintes requisitos:

$\checkmark$ Realizar coleta de amostra do receptor, exclusivas para exames imunohematológicos, após conferência da prescrição e da requisição de transfusão, com identificação dos tubos no momento da coleta (nome completo do paciente, data, número do registro e assinatura do coletor).

$\checkmark$ Realizar identificação e registro seguro e adequado das amostras recebidas e enviadas.

$\checkmark$ Assegurar a resolução e tratamento de discrepâncias dos dados da amostra coletada com a requisição e a prescrição de transfusão.

$\checkmark$ Aceitar apenas amostras rotuladas de forma completa, precisa e legível.

$\checkmark$ Possuir sistema de registro de antecedentes transfusionais e de resultados de exames imuno-hematológicos em amostras de pacientes atendidos.

$\checkmark$ Possuir sistema que permita rastreabilidade dos componentes transfundidos, com histórico transfusional e com resultados dos testes imunohematológicos e de aloimunizações.

$\checkmark$ Realizar a retipagem das bolsas dos hemocomponentes a serem compatibilizadas e transfundidas.

$\checkmark$ Realizar os testes pré-transfusionais (determinação $A B O / R h$ direta e reversa, pesquisa de anticorpos irregulares, teste de Coombs Direto quando necessário, e testes adicionais que se façam necessários para cada caso).

$\checkmark$ Realizar prova de compatibilidade para concentrado de hemácias com amostra com, no máximo, 72 horas da coleta.

$\checkmark$ Nos casos de receptores com pesquisa de anticorpos irregulares positivo realizar a identificação do anticorpo pelo próprio serviço ou encaminhar a amostra a laboratório de referência. Selecionar concentrado de hemácia que não contenha os antígenos correspondentes aos anticorpos identificados.

$\checkmark$ Conferir os registros relativos à tipagem sanguínea, pesquisa de anticorpos irregulares e Prova de Compatibilidade antes da liberação dos hemocomponentes para transfusão. 
$\checkmark$ Realizar testes pré-transfusionais para plasma, plaqueta e crio.

$\checkmark$ Registrar, conferir e liberar os resultados dos testes pré-transfusionais realizados de maneira segura.

$\checkmark$ Apresentar documentação relativa ao setor assinada pelo técnico responsável.

$\checkmark$ Liberar transfusão incompatível somente se houver justificativa por escrito, assinada pelo médico hemoterapeuta e/ou médico do paciente.

$\checkmark$ Realizar identificação adequada dos hemocomponentes preparados para transfusão e sua inspeção visual no ato da liberação para transfusão;

$\checkmark$ Providenciar a guarda adequada e segura das amostras do doador/bolsa e do receptor após a transfusão conforme tempo definir definido por cada serviço.

$\checkmark$ Realizar e conferir os registros relativos à liberação dos hemocomponentes, da transfusão e dos testes pré-transfusionais. 


\section{Ato transfusional}

Todo processo de transfusão se inicia pela requisição transfusional devidamente preenchida e assinada por médico habilitado. A Agência Transfusional deve seguir os seguintes requisitos:

$\checkmark$ Realizar procedimentos adequados e seguros em relação às solicitações dos hemocomponentes e liberação para o ato transfusional.

$\checkmark$ Receber as solicitações para transfusão de sangue ou componentes (requisição), em formulário específico que contenha informações suficientes para uma correta identificação do receptor, com preenchimento de todos os dados de forma clara, sem rasuras ou abreviações e com registro profissional e assinatura do médico.

$\checkmark$ Realizar atendimento de solicitação de hemocomponente somente com requisição de transfusão e quando necessário possuir médico hemoterapeuta para análise das requisições.

$\checkmark$ Realizar pesquisa sistemática dos registros antes do ato transfusional.

$\checkmark$ Possuir formulário específico para autorização do atendimento à solicitação de extrema urgência.

$\checkmark$ Realizar procedimentos adequados quanto a fracionamento/alicotagem de hemocomponente.

$\checkmark$ Garantir o preenchimento adequado do Termo de Ciência de Transfusão, com assinatura no prontuário do paciente que recebe hemocomponentes e hemoderivados na unidade.

$\checkmark$ Garantir o registro no prontuário do paciente de toda prescrição médica e/ou de hemocomponentes, do início e término da transfusão de cada bolsa com registro dos sinais vitais, dos números e da origem dos hemocomponentes, das reações adversas às transfusões e das condutas adotadas, com identificação do profissional que realizou o procedimento transfusional.

$\checkmark$ Realizar adequado arquivamento dos registros relativos à transfusão.

$\checkmark$ Possuir protocolo e realizar os procedimentos adequados relativos à reintegração de hemocomponentes ao estoque, segundo normas vigentes. 
$\checkmark$ Realizar gerenciamento, organização e arquivamento dos prontuários dos pacientes de forma segura e adequada ao setor.

$\checkmark$ Arquivar de maneira organizada os prontuários dos pacientes de forma a permitir sua localização a qualquer tempo e assegurar sua preservação.

$\checkmark$ Realizar conservação e organização dos prontuários dos pacientes com registros formais de boa qualidade e que permitam rastreabilidade confiável das informações.

$\checkmark$ Assegurar prescrições médicas e de enfermagem adequadas ao serviço realizado, com registros e identificação correta dos profissionais (inclusive registro profissional).

$\checkmark$ Garantir a realização da prescrição médica para pacientes atendidos ambulatorialmente (transfusão e sangria).

$\checkmark$ Possuir procedimentos adequados relativos às extrações terapêuticas de sangue (sangrias) realizadas na unidade de acordo com critérios estabelecidos nas normas vigentes.

$\checkmark$ Realizar acompanhamento adequado durante todo o processo de transfusão, incluindo monitoramento e atendimento a intercorrências (reações adversas), com registro das ações realizadas conforme normas técnicas vigentes.

$\checkmark$ Utilizar equipos para transfusão com filtro estéril de uso único e descartável e realizar preparo do sistema transfusional observando as normas técnicas vigentes.

$\checkmark$ Possuir sistemática de gerenciamento dos procedimentos transfusionais ambulatoriais. Em caso de uso de sistema seja informatizado, verificar se é seguro, de fácil utilização e tem informações rastreáveis. Caso os registros sejam manuais, verificar se os mesmos são legíveis, rastreáveis e organizados.

$\checkmark$ Garantir a adequada avaliação médica pré-transfusional de todos os pacientes atendidos e supervisão médica em todos os procedimentos hemoterápicos nas dependências da unidade. 


\section{Comitê Transfusional, Hemovigilância e Retrovigilância}

Toda instituição de assistência à saúde que realiza transfusão de hemocomponentes deverá compor ou fazer parte de um Comitê Transfusional, que tem como competência o monitoramento da prática hemoterápica na instituição visando o uso racional do sangue, a atividade educacional continuada em hemoterapia, a hemovigilância e a elaboração de protocolos de atendimento da rotina hemoterápica. Os requisitos para atuação do comitê transfusional são:

Estar devidamente formalizado e atuante como referência e consultoria na prática hemoterápica para os profissionais da instituição mantendo-os atualizados e informados.

$\checkmark$ Realizar reuniões periódicas devidamente registradas com participação da maioria de seus membros, sendo importante ter um representante da Agência Transfusional.

$\checkmark$ Promover atividades educativas com ações voltadas para sensibilização, informação e treinamento adequados de todos os profissionais envolvidos com acompanhamento e notificação de incidentes transfusionais na instituição ou serviço conveniado, realizando adequado registro do conteúdo programático e da lista de presença.

$\checkmark$ Participar da elaboração e atualização dos Protocolos de Monitoramento da Prática Hemoterápica e da definição de condutas nas diversas situações.

$\checkmark$ Utilizar como referência o Manual Técnico de Hemovigilância da ANVISA e o Guia para uso de hemocomponentes do Ministério da Saúde.

$\checkmark$ Possuir sistemática de notificação e investigação de incidentes transfusionais, adotando o modelo de FIT (Ficha de Notificação e Investigação de Incidentes Transfusionais Imediatos) com registros corretamente preenchidos.

$\checkmark$ Realizar registro no prontuário do paciente das informações relativas às reações transfusionais e as medidas preventivas e/ou corretivas adotadas. 
$\checkmark$ Notificar eventos adversos a transfusões no sistema NOTIVISA, incluindo sua resolução em casos de reações transfusionais (deteç̧ão, tratamento e prevenção).

$\checkmark$ Participar do processo de retrovigilância (investigação de possíveis infecções em receptores associadas a soroconversão de doadores) desencadeado pelo serviço de hemoterapia fornecedor de hemocomponentes.

$\checkmark$ Garantir que os procedimentos relativos a Hemovigilância e Soroconversão sejam implantados, atualizados e realizados adequadamente até o encerramento do processo de investigação, de forma segura e segundo normas vigentes.

Nos casos de soroconversão de receptor a Agência Transfusional deve comunicar o serviço fornecedor do hemocomponente para ações com o doador. 


\section{Referências Bibliográficas}

AABB. Quality Management Systems: Theory and Practice. In: ROBACK, J. D. Technical Manual. 18. ed. Bethesda: American Association of Blood Banks, 2014. Cap. 1, p. 1-39

BRASIL. Ministério da Saúde. Resolução RDC n 151, de 21 de agosto de 2001. Aprova o Regulamento Técnico sobre Níveis de Complexidade dos Serviços de Hemoterapia, que consta como anexo. Diário Oficial [da] República Federativa do Brasil, Poder Executivo, Brasília, DF, 22 ago. 2001.

BRASIL. Ministério da Saúde. Resolução RDC n 50, de 21 de fevereiro de 2002. Dispõe sobre o Regulamento Técnico para planejamento, programação, elaboração e avaliação de projetos físicos de estabelecimentos assistenciais de saúde. Diário Oficial [da] República Federativa do Brasil, Poder Executivo, Brasília, DF, 20 mar. 2002.

BRASIL. Ministério da Saúde. Resolução RDC nํ 306, de 07 de dezembro de 2004. Dispõe sobre o Regulamento Técnico para o gerenciamento de resíduos de serviços de saúde. Diário Oficial [da] República Federativa do Brasil, Poder Executivo, Brasília, DF, 10 dez. 2004.

BRASIL. Ministério da Saúde. Resolução RDC n 63, de 25 de novembro de 2011. Dispõe sobre os Requisitos de Boas Práticas de Funcionamento para os Serviços de Saúde. Diário Oficial [da] República Federativa do Brasil, Poder Executivo, Brasília, DF, 28 nov. 2011. Seção 1, p. 44-46.

BRASIL. Ministério da Saúde. Resolução RDC nํ 15, de 15 de março de 2012. Dispõe sobre o Regulamento Técnico para o gerenciamento de resíduos de serviços de saúde. Diário Oficial [da] República Federativa do Brasil, Poder Executivo, Brasília, DF, 19 mar. 2012.

BRASIL. MINISTÉRIO DA SAÚDE. Secretaria de Atenção à Saúde. Departamento de Atenção Especializada. Guia para o uso de Hemocomponentes. Brasília: Editora do Ministério da Saúde, 2014.

BRASIL. Ministério da Saúde. Resolução RDC no 34, de 11 de junho de 2014. Dispõe sobre as Boas Práticas no Ciclo do Sangue. Diário Oficial [da] República Federativa do Brasil, Poder Executivo, Brasília, DF, 16 jun. 2014.

BRASIL. Ministério da Saúde. Portaria de Consolidação ํㅜ 5, de 03 de outubro de 2017. Consolidação das normas sobre as ações e os serviços de saúde do Sistema Único de Saúde. Anexo IV - Do sangue, componentes e derivados. Diário Oficial [da] República Federativa do Brasil, Poder Executivo, Brasília, DF, 03 out. 2017. Seção 1, p. 222-353. 
COVAS, D. T. UBIALI, E. M. A. SANTIS, G. C. De. Manual de Medicina Transfusional. 2ª Ed. São Paulo: Atheneu, 2014.

SAKUMA, A.; OTTOBONI, M. A. P.; SIERRA, P. C. Manual para controle da qualidade do sangue total e hemocomponentes. São Paulo: RedSang - SIBRATEC, v. $120,2011$. 